\title{
COMPARAÇÃO ENTRE OS GRAUS DE EFICIÊNCIA DO TRATAMENTO DA MÁ OCLUSÃO \\ DE CLASSE II REALIZADO COM O APARELHO PENDULUM E COM AS EXTRAÇÕES DE DOIS PRÉ-MOLARES SUPERIORES
}

Tese apresentada à Faculdade de Odontologia de Bauru, da Universidade de São Paulo, como parte dos requisitos para a obtenção do título de Doutora em Odontologia, área de Ortodontia.

(Edição Revisada) 


\section{COMPARAÇÃO ENTRE OS GRAUS DE EFICIÊNCIA DO TRATAMENTO DA MÁ OCLUSÃO \\ DE CLASSE II REALIZADO COM O APARELHO PENDULUM E COM AS EXTRAÇÕES DE DOIS PRÉ-MOLARES SUPERIORES}

Tese apresentada à Faculdade de Odontologia de Bauru, da Universidade de São Paulo, como parte dos requisitos para a obtenção do título de Doutora em Odontologia, área de Ortodontia.

(Edição Revisada)

Orientador: Prof. Dr. Arnaldo Pinzan 


\begin{tabular}{|l|}
\hline Pinzan-Vercelino, Célia Regina Maio \\
P658c Comparação entre os graus de eficiência do tratamento \\
da má oclusão de Classe II realizado com o aparelho \\
Pendulum e com as extrações de dois pré-molares \\
superiores / Célia Regina Maio Pinzan-Vercelino - Bauru, \\
2005. \\
158 p. + apêndices: il.; $30 \mathrm{~cm}$. \\
Tese (Doutorado) - Faculdade de Odontologia de Bauru - \\
Universidade de São Paulo. \\
Orientador: Prof. Dr. Arnaldo Pinzan.
\end{tabular}
Autorizo, exclusivamente para fins acadêmicos e científicos, a reprodução total ou parcial desta dissertação, por processos fotocopiadores e/ou meios eletrônicos.

Assinatura da autora:

Data: 5 de agosto de 2005

Data da aprovação pelo Comitê de Ética em Pesquisa da FOB:

1 de julho de 2005.

A cópia do parecer de aprovação encontra-se no final do capítulo "Apêndice". 


\section{CÉLIA REGINA MAIO PINZAN - VERCELINO}

19 de novembro de 1976

Bauru - SP

Nascimento

Filiação

Arnaldo Pinzan

Célia A. M. Pinzan

1995-1998

Curso de Odontologia pela Faculdade de Odontologia de Bauru - Universidade de São Paulo.

$1999-2001$

Curso de Aperfeiçoamento em Ortodontia pela Assessoria e Consultoria de Ortodontia, Pesquisa e Ensino.

2000-2001

Curso de Pós-graduação em Ortodontia, ao nível de mestrado, pela Faculdade de Odontologia de Bauru Universidade de São Paulo.

$2001 \ldots$

Professora da disciplina de Ortodontia, Departamento de Odontologia da Universidade do Sagrado Coração.

2003-2005

Curso de Pós-graduação em Ortodontia, ao nível de doutorado, pela Faculdade de Odontologia de Bauru Universidade de São Paulo.

Associação

Associação Paulista de Cirurgiões-Dentistas. 
"Mude seus pensamentos e estará mudando o seu mundo"

Norman Vincent Peale

(1898 - 1993) 


\section{Dedico este trabalho, com o meu mais profundo afeto}

Aos meus queridos pais ARNALDO e CÉLIA por todo amor e dedicação durante toda a minha vida. Ao meu pai, pelo exemplo de ser humano, por toda a sua honestidade e caráter, mesmo quando a vida colocou alguns obstáculos em seu caminho. Além de professor de Ortodontia, você é um mestre da minha vida. À minha mãe simplesmente por ser a pessoa maravilhosa, doce e terna que é. Não tenho palavras para expressar a minha gratidão à sua dedicação, ao amor, à doação e ao carinho dispensados ao Guilherme durante todos os momentos em que eu tive que me ausentar.

Aos meus pequenos grandes amores GUILHERME e HENRIQUE, por serem a razão do meu existir, a força para eu enfrentar os momentos de luta e as minhas fontes de felicidade. GUILHERME, cada sorriso seu, cada gesto de carinho e de amor foram imprescindíveis para mim nesta fase da minha vida, você não pode imaginar o quanto foi importante nesta conquista. HENRIQUE, apesar de ainda não termos nos visto, você emanou dentro de mim toda a força e determinação que eu precisei para estar aqui hoje. Amo vocês mais do que tudo. 
Às minhas queridas irmãs VERIDIANA e LUCIANA pela amizade incondicional e por terem me "substituído", com muito amor e dedicação, nos momentos em que eu estive ausente ao meu filho.

Ao $\boldsymbol{A L A N}$, pelo amor, confiança, incentivo e companheirismo. Por entender, sem cobranças, os momentos de ausência, mesmo quando estive presente. Agradeço ainda a paciência na espera por este momento. 


\section{Agradecimentos especiais}

À DEUS pela vida maravilhosa que me concede. Pelas pessoas especiais que colocou em minha vida. Por ser a minha luz e a minha força constante. 


\section{Agradecimentos especiais}

Ao meu orientador, Prof. Dr. ARNALDO PINZAN, por toda a confiança em mim depositada na realização deste estudo. Obrigada pela paciência e presteza nas infinitas solicitações. Agradeço ainda por despertar em mim o espírito crítico na ciência, pelo exemplo de seriedade e dedicação dos verdadeiros mestres. 


\section{Agradecimentos especiais}

Ao Prof. Dr. GUILHERME JANSON, por toda a contribuição necessária durante a realização deste estudo. Pelo seu exemplo de seriedade e dedicação à profissão. Agradeço ainda pela dedicação durante a realização deste curso, despertando-nos o senso crítico e a acuidade durante a realização de estudos científicos.

Ao Prof. Dr. RENATO RODRIGUES DE ALMEIDA, por possibilitar a realização deste estudo, concedendo prontamente parte da amostra. Sem o seu desprendimento, seria impossível a realização deste estudo. 


\section{Agradecimentos especiais}

Ao coordenador do curso de Doutorado, Prof. Dr. José Fernando

Castanha Henriques, por toda a seriedade e dedicação com que conduziu todo o curso, mesmo com todas as responsabilidades administrativas exercidas junto à Prefeitura do Campus desta Universidade.

Ao Prof. Dr. MARCOS ROBERTO DE FREITAS, chefe do departamento de Odontopediatria, Ortodontia e Saúde Coletiva, pelos conhecimentos transmitidos de forma simples, pela convivência, pela amizade e carinho durante toda a minha vida.

Ao Prof. Dr. DÉCIO RODRIGUES MARTINS, por ser o responsável pelas conquistas de todos dentro desta disciplina. 


\section{Agradeço ainda}

Aos meus avós JOÃO MAIO, OLGA, JOÃO PINZAN e IRMA por todo o amor ao longo de minha vida e pelo incentivo constante. Em especial ao meu avô, JOÃO MAIO, que nos deixou, no início deste ano, para se tornar a luz que, constantemente, nos guia. Sinto saudades.

Aos meus tios MARIA HERMÍNIA, SÔNIA, JOÃO CARLOS e ELIANA e aos primos RICARDO, CLÁUDIA, LÍGIA, LUÍZA, JÚLIA, ENEIDA, ANDREW, MARINA E LUANA pelo amor e carinho. Em especial a SÔNIA, sempre tão solícita, que também me ajudou demais com o Guilherme.

À minha sogra, CÉLIA, por todo o carinho e atenção e, principalmente, por exercer, com infinito amor, o meu papel junto ao meu filho, nos momentos em que me ausento.

Ao meus cunhados CLÁUDIO, ALEX e EDIVANI, pelos momentos de descontração, tão necessários ao longo destes anos.

Às amigas DANIELA AGOSTINHO, DANIELE, ALINE GRACIANO, MICHELE, ANA CAROLINA, ALINE NASRALLA e FERNANDA DUARTE por toda atenção, incentivo e carinho, principalmente nos momentos de desânimo.

Ao "tio" LUís e "tia" LENI pela amizade sincera e por todo o apoio e carinho que sempre tiveram por nós. 
Aos amigos do Curso de Doutorado ANALU, FABRÍCIO, FERNANDA, JOSÉ EDUARDO, KARINA FREITAS, KARINA LIMA, LENIANA, REJANE, RICARDO e RODRIGO pelos momentos de convívio e pela troca de experiências.

À KARINA pela amizade sincera ao longo destes anos, por compartilhar comigo de muitos momentos tão importantes quanto este e pelo auxílio e disponibilidade nos momentos em que precisei.

À FERNANDA ANGELIERI, minha companheira de viagem, pela amizade, carinho e incentivo desde a graduação.

Ao RODRIGO CANÇADO, por todo o auxílio na elaboração da estatística deste trabalho.

Ao SÉRGIO ESTELITA BARROS, por atender prontamente todas as solicitações e por ter realizado a calibração para a medição dos índices oclusais.

Ao MARCOS JANSON, pela colaboração nos dados cefalométricos deste estudo.

Aos funcionários da disciplina de Ortodontia CRISTINA, NEIDE, SÉRGIO e VERA pela atenção e carinho que sempre tiveram por mim.

Ao DANIEL por todo o auxílio e colaboração na área da informática, durante a realização deste trabalho. 
À $\mathrm{Sr}^{\mathrm{a}}$. ARLETE, Sr ${ }^{\mathrm{a}}$. MARILENE, Sr $\stackrel{\text { a }}{ }$. ODETE, Sr ${ }^{\mathrm{a}}$. TEREZA MARIA, RENATA, FERNANDO, MÁRCIO, PATRÍCIA, DANIEL, RAFAEL, FERNANDA e MARIA FERNANDA pela convivência ao longo destes anos.

Aos funcionários da ACOPEN ADÉLIA, CÉSAR, LUCIANA, SÔNIA e WALTER por toda amizade e carinho.

À Faculdade de Odontologia de Bauru - Universidade de São Paulo, representada pela Digníssima Diretora Prof ${ }^{\mathrm{a}}$. $\mathrm{Dr}^{\mathrm{a}}$. MARIA FIDELA DE LIMA NAVARRO.

Ao Prof. Dr. JOSÉ CARLOS PEREIRA, Presidente da Comissão de Pós-Graduação da Faculdade de Odontologia de Bauru - Universidade de São Paulo.

Aos PROFESSORES da Faculdade de Odontologia de Bauru, responsáveis pela minha formação acadêmica.

Ao Prof. Dr. EDUARDO BATISTA FRANCO, tutor do Programa Especial de Treinamento, pela confiança e pelo incentivo à minha iniciação na carreira docente, despertando em mim o interesse pela carreira acadêmica.

Aos funcionários da Biblioteca pelas orientações, presteza e simpatia com que sempre me atenderam.

Aos funcionários da Pós-Graduação por toda a atenção despendida.

À Coordenação de Aperfeiçoamento de Pessoal de Nível Superior (CAPES) pelos meses de bolsa de estudo concedidos. 
À Magnífica Reitora da Universidade do Sagrado Coração Ir. JACINTA TUROLLO GARCIA, ao Pró-Reitor de Pesquisa e Coordenador dos cursos de Pós-Graduação JOSÉ JOBSON DE ARRUDA ANDRADE, à Digníssima Diretora do Centro de Ciências Biológicas e Profissões da Saúde Ir. ADELYR WEBER e à Coordenadora do Curso de Odontologia CLÁUDIA DE ALMEIDA PRADO PICINO SAGVIOLI por toda a confiança em mim depositada.

Aos Profs. EDUARDO, FABÍOLA, LEDA, MÁRCIA e RENATO pela amizade, atenção e substituição nos momentos de ausência.

A todos que direta ou indiretamento contribuíram para a realização deste trabalho. 


\section{SUMÁRIO}

LISTA DE FIGURAS.................................................................... xviii

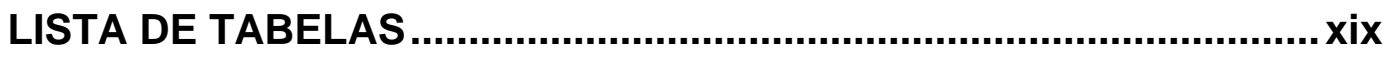

RESUMO …......................................................................................... XXi

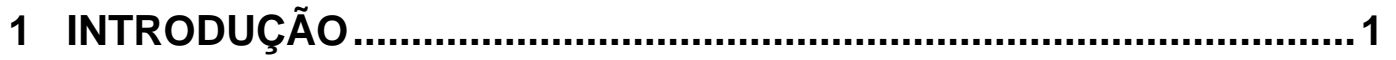

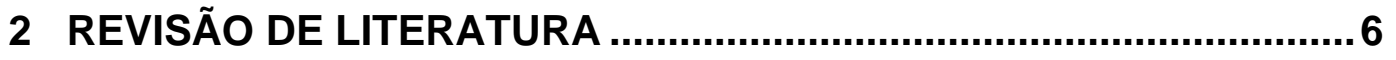

2.1 Aparelho Pendulum........................................................... 8

2.1.1 Ativação do aparelho Pendulum ........................................ 11

2.1 .2 Indicações ............................................................... 13

2.1.3 Contra-indicações ............................................................. 14

2.1.4 Efeitos ocasionados pelo aparelho Pendulum .......................... 15

2.1.5 Quantidade de correção da relação molar .................................. 25

2.1.6 Presença dos segundos molares superiores .......................... 27

2.1.7 Contenção dos primeiros molares permanentes após a distalização ........................................................ 29

2.1.8 Pendulum $X$ tempo de tratamento.................................. 31

2.1.9 Efeitos colaterais dos distalizadores intrabucais ....................... 32

2.2 Extrações de dois pré-molares superiores.................................... 33

2.2 .1 Indicações ................................................................... 38

2.2.2 Estudos concernentes às extrações de dois prémolares superiores .................................................. 40

2.2.3 Extrações dentárias $X$ tempo de tratamento .......................... 44

2.3 Índices oclusais. ........................................................... 48

2.3.1 Índice de Prioridade de tratamento (IPT) …............................ 49

2.3.2 Peer Assessment Rating (PAR) ....................................... 50

2.4 Considerações gerais sobre este capítulo .................................52 
4 MATERIAL E MÉTODOS .......................................................... 56

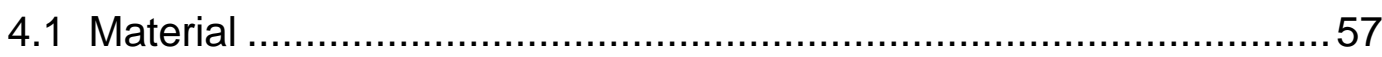

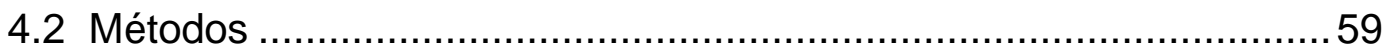

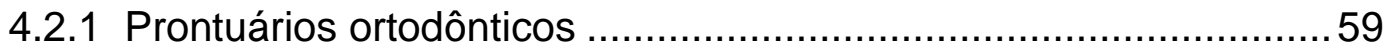

4.2.2 Tratamento ortodôntico ....................................................... 60

4.2.3 Traçados e medições das radiografias ...................................... 64

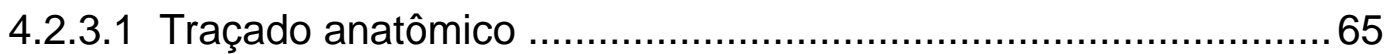

4.2.3.2 Pontos de referência, linhas e planos ...................................6 67

4.2.3.3 Grandezas cefalométricas esqueléticas................................ 75

4.2.3.4 Grandezas cefalométricas dentárias .................................... 79

4.2.3.5 Relações dentárias......................................................... 83

4.2.3.6 Grandezas cefalométricas tegumentares............................. 85

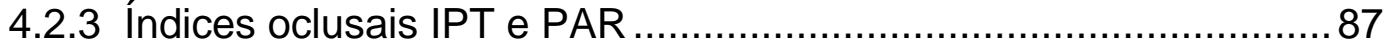

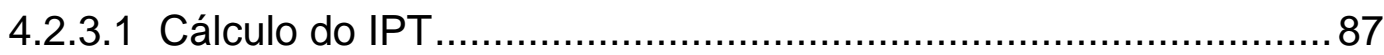

4.2.3.2 Cálculo do PAR ......................................................... 91

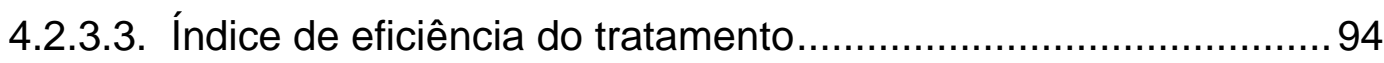

4.3 Análise estatística ............................................................ 95

4.3.1 Erro do método .......................................................... 95

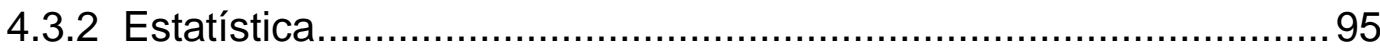

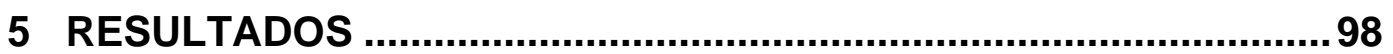

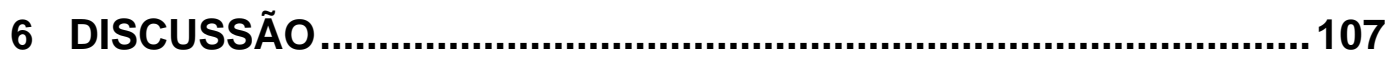

6.1 Amostra utilizada..................................................... 108

6.2 Metodologia aplicada ......................................................... 111

6.3 Precisão da metodologia..................................................... 114

6.4 Resultados obtidos.......................................................... 117

6.4.1 Compatibilidade dos grupos........................................... 117

6.4.2 Resultados oclusais ...................................................... 121

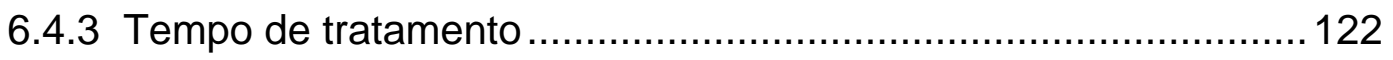


6.4.4 A eficiência do tratamento ortodôntico ................................... 130

6.5 Avaliação dos índices oclusais.............................................. 134

6.6 Implicações clínicas ............................................................... 136

6.7 Sugestões para novos trabalhos ..................................... 138

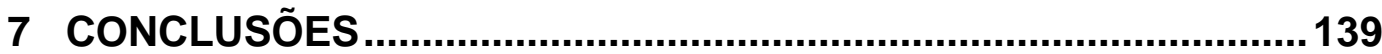

REFERÊNCIAS BIBLIOGRÁFICAS............................................. 141

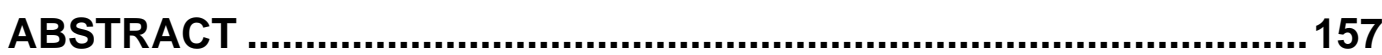

APÊNDICE 


\section{LISTA DE FIGURAS}

FIGURA 1 - Aparelho Pendulum (A - início do tratamento; B - pósdistalização).

FIGURA 2 - Tratamento com extrações de dois pré-molares superiores....62

FIGURA 3 - Desenho anatômico .65

FIGURA 4 - Pontos de referência.. .70

FIGURA 5 - Linhas e planos.. .73

FIGURA 6 - Grandezas cefalométricas esqueléticas. .77

FIGURA 7 - Grandezas cefalométricas dentárias. .81

FIGURA 8 - Relações dentárias. .83

FIGURA 9- Grandezas cefalométricas tegumentares. .85 


\section{LISTA DE TABELAS}

TABELA 1 - Critérios de aplicação dos escores para os componentes do índice IPT. 89

TABELA 2 - Critérios de aplicação dos escores para os componentes do índice PAR 92

TABELA 3 - Resultados do teste $t$ dependente e da fórmula de Dahlberg, aplicados às variáveis cefalométricas para estimar os erros sistemáticos e casuais, respectivamente. 100

TABELA 4 - Resultados do teste $t$ dependente e da fórmula de Dahlberg, aplicados aos índices oclusais IPT e PAR para estimar os erros sistemáticos e casuais, respectivamente. 101

TABELA 5 - Resultados do teste $t$ independente para avaliar a compatibilidade entre os grupos quanto às variáveis cefalométricas..... 102

TABELA 6 - Resultado do teste Qui-Quadrado para avaliar a compatibilidade dos grupos quanto à proporção entre os gêneros. 103

TABELA 7 - Resultado do teste Qui-Quadrado para avaliar a compatibilidade dos grupos quanto à proporção dos tipos de má oclusão de Classe II. 103

TABELA 8 - Resultado do teste Qui-Quadrado para avaliar a compatibilidade dos grupos quanto à discrepância ântero-posterior. .... 103

TABELA 9 - Resultados do teste $t$ independente aplicados às variáveis estudadas, nos grupos 1 e 2 . 104 
TABELA 10 - Resultados da análise de regressão linear múltipla, considerando o valor final do índice PAR como variável dependente.... 104

TABELA 11 - Resultados do teste não paramétrico de Mann-Whitney entre os escores finais de cada um dos componentes do índice PAR dos grupos 1 e 2 105

TABELA 12 - Resultados do teste de correlação de Pearson aplicado às variáveis IPTF e PARF e PcIPT e PCPAR. ............................................ 105 
Resumo 


\section{RESUMO}

O objetivo deste estudo retrospectivo foi o de comparar os graus de eficiência do tratamento da má oclusão de Classe II, realizado com o aparelho Pendulum e com extrações de dois pré-molares superiores. A amostra constituiu-se dos modelos de gesso e das telerradiografias de 48 pacientes com má oclusão de Classe II, divididos em dois grupos de acordo com o protocolo de tratamento, sendo que ambos os grupos utilizaram o aparelho fixo. O grupo 1 foi composto por 22 pacientes tratados com o aparelho Pendulum, com idade inicial média de 14,44 \pm 1,85 anos (idade mínima de 11,6 e máxima de 17,65), sendo 7 do gênero masculino e 15 do feminino. $\mathrm{O}$ grupo 2 constituiu-se por 26 pacientes tratados com extrações de dois pré-molares superiores, com idade inicial média de 13,66 \pm 0,91 anos (idade mínima de 12 e máxima de 15,08), sendo 14 do gênero masculino e 12 do feminino. Para a comparação entre os graus de eficiência, os resultados oclusais dos tratamentos foram avaliados em modelos de gesso por meio dos índices oclusais IPT e PAR, enquanto que o tempo de tratamento de cada grupo foi calculado a partir das anotações clínicas presentes nos prontuários. O grau de eficiência foi calculado pela porcentagem de melhora oclusal, avaliada pelo IPT e PAR, dividida pelo tempo de tratamento. Os índices oclusais iniciais e finais, o tempo de tratamento e o grau de eficiência dos protocolos avaliados foram comparados por meio do teste $t$ independente. Os resultados 
demonstraram que o grupo 2 apresentou um maior grau de eficiência do que o grupo 1, com um tempo de tratamento significantemente menor. 


\section{Introdução}




\section{INTRODUÇÃO}

Os diversos protocolos de tratamento descritos na literatura para a correção da má oclusão de Classe II despertam um intenso interesse na comunidade ortodôntica. Esta curiosidade encontra-se intimamente relacionada ao fato desta má oclusão estar presente em uma porcentagem significativa dos pacientes atendidos nas clínicas ortodônticas $^{6,17,74,109}$. Na população em geral, a Classe II encontra-se presente em 25 a 30\% dos indivíduos e entre os pacientes ortodônticos, acomete aproximadamente $60 \%{ }^{6}$. O alto porcentual de procura para 0 tratamento relaciona-se ao grande desequilíbrio estético e funcional que esta má oclusão encontra-se relacionada.

Os protocolos de tratamento propostos como extrações dentárias, aparelhos ortopédicos funcionais, distalizadores e ortodôntico-cirúrgico relacionam-se às características pertinentes a cada má oclusão de Classe II, à idade, às implicações psicológicas do paciente, às condições financeiras, aos riscos de danos aos tecidos dentários e ao periodonto de sustentação, à complexidade do tratamento, à duração, à estabilidade, à colaboração e ao grau de eficiência do protocolo a ser encetado $^{7,29,67,79,82,106}$.

É de interesse tanto do profissional quanto do paciente a realização de um plano de tratamento o mais eficiente possível, onde os melhores resultados sejam obtidos num menor período de tempo ${ }^{7}$. Assim, quando 
mais de um protocolo de tratamento pode ser utilizado na correção de uma mesma má oclusão, deve-se optar por aquele que apresente comprovadamente uma maior eficiência ${ }^{7}$.

Para a má oclusão de Classe II dentária, sem comprometimento esquelético significativo, potencial de crescimento craniofacial reduzido e sem uma quantidade significativa de apinhamento e/ou protrusão no arco inferior, os protocolos de tratamento normalmente se relacionam às extrações de dois pré-molares superiores ou à utilização de aparelhos distalizadores $\mathrm{s}^{40-43,47,62}$.

Entre os aparelhos distalizadores propostos na literatura, encontrase o Pendulum proposto por Hilgers ${ }^{47}$, em 1992. Este aparelho foi desenvolvido para pacientes com má oclusão de Classe II, não cooperadores na utilização do aparelho extrabucal e que, provavelmente, teriam que extrair os pré-molares superiores para a sua correção. Vários estudos $^{19,20,25,35,37,60}$ relatam o sucesso do aparelho Pendulum na obtenção da distalização dos molares superiores, contudo com efeitos adversos como a protrusão dos incisivos, a mesialização dos caninos e dos pré-molares superiores, o aumento do trespasse horizontal, o aumento da altura facial anterior e a inclinação para distal da coroa dos molares, o que segundo os autores ${ }^{19,20,25,35,37,60}$, seriam corrigidos durante o tratamento ortodôntico fixo. No entanto, posteriormente ao uso do Pendulum, para a obtenção da distalização das raízes dos molares e para a manutenção da correção da relação molar durante a retração anterior, torna-se necessário utilizar um aparelho extrabucal ${ }^{37,38,40}$. Se esta foi a 
opção de tratamento em função da não colaboração do paciente, nesta fase, onde ela se torna imprescindível para a obtenção dos melhores resultados, a eficiência do tratamento poderá ser comprometida.

As extrações de dois pré-molares superiores no tratamento da má oclusão de Classe II já foram e ainda são muito discutidas na literatura. Os fatores indicadores da necessidade de extrações dentárias no tratamento da má oclusão de Classe II baseiam-se na sua severidade, no reduzido potencial de crescimento frente à magnitude da discrepância ântero-posterior, na falta de cooperação do paciente, na preocupação com o perfil facial e no padrão de crescimento facial, entre outros fatores ${ }^{8}$. A decisão entre extrair ou não dentes pode influenciar os resultados estéticos e oclusais finais, a satisfação dos pacientes e familiares e também a duração do tratamento ${ }^{90,110}$.

Alguns trabalhos já evidenciaram que este protocolo demonstrou melhores resultados oclusais do que quando foram realizadas as extrações de quatro pré-molares ${ }^{14,51}$ e também quando comparadas ao tratamento sem extrações ${ }^{7}$.

Ao analisarmos estas duas modalidades de tratamento, surgiram algumas especulações que nos levaram a realizar este estudo:

- com o aparelho Pendulum "cria-se" um espaço semelhante ao das extrações dos pré-molares superiores, que depois deverá ser fechado, com dependência da colaboração do paciente na utilização do aparelho extrabucal para distalizar as raízes e possibilitar a retração anterior sem perda de ancoragem 
significativa. Caso não ocorra a colaboração do paciente, não haveria um aumento do tempo de tratamento e/ou um comprometimento dos resultados oclusais?

- o tratamento com extrações de dois pré-molares superiores despendem maior tempo para a sua conclusão?

A fim de investigarmos estas especulações e uma vez que tanto o aparelho Pendulum como a realização das extrações de dois pré-molares superiores podem ser indicados para o tratamento das más oclusões de Classe II com características morfológicas semelhantes, propusemo-nos a comparar os graus de eficiência entre estes dois protocolos de tratamento, considerando-se os resultados oclusais obtidos e o tempo de tratamento despendido. 
2 Revisão de literatura 


\section{REVISÃO DE LITERATURA}

Muitas terapêuticas apresentam-se disponíveis aos ortodontistas para o tratamento da Classe II. A variedade de aparelhos para a sua correção reflete as diferentes combinações dos componentes esqueléticos e dentários aos quais esta má oclusão pode estar relacionada: protrusão maxilar esquelética adicionada ou não a um tamanho maxilar aumentado; protrusão dentária superior; retrusão mandibular esquelética associada ou não a uma mandíbula de tamanho diminuído; retrusão dentária inferior e/ou ângulo da base do crânio obtuso $23,32,55-57,74,80,91-93$.

Para a correção da má oclusão de Classe II dentária, sem comprometimento esquelético significativo, potencial de crescimento craniofacial reduzido e sem uma quantidade significativa de apinhamento e/ou protrusão no arco inferior, os protocolos de tratamento normalmente se relacionam às extrações de dois pré-molares superiores ou à utilização de aparelhos distalizadores ${ }^{41-43}$.

Vários aparelhos distalizadores já foram propostos na literatura ${ }^{39,40,47,62,63}$. Entre eles existem os que dependem da colaboração do paciente ${ }^{62,63}$ e os que exigem uma cooperação mínima $22,40,47,54,113$. O aparelho Pendulum constitui-se em um distalizador intrabucal cujo grau de dependência em sua utilização é mínima ${ }^{47}$, ou seja, demanda do paciente um mínimo de dedicação e assiduidade no seu uso ${ }^{109}$. Sabe-se 
que a cooperação do paciente na utilização dos dispositivos intra e/ou extrabucais encontra-se intimamente relacionada ao sucesso, ao tempo e ao custo do tratamento ${ }^{60}$.

Como o objetivo deste estudo é o de comparar os graus de eficiência dos tratamentos realizados com o aparelho Pendulum e com extrações de dois pré-molares superiores, aplicando-se os índices oclusais IPT e PAR, esta revisão de literatura abordará os seguintes tópicos:

2.1 Aparelho Pendulum

2.2 Extrações de dois pré-molares superiores

2.3 Índices oclusais

2.4 Considerações gerais sobre este capítulo

\subsection{Aparelho Pendulum}

O aparelho Pendulum, foi preconizado por HILGERS ${ }^{47}$, em 1992, com o intuito de promover a distalização dos molares superiores com mínima colaboração do paciente. Este aparelho é constituído por um botão palatino de Nance, molas de titânio-molibdênio (TMA) e grampos de apoio. O botão de resina acrílica (botão palatino de Nance) localiza-se no palato e atua como ancoragem além de reter a mola do aparelho. Este 
botão estende-se com suas bordas arredondadas sobre o palato e mantém uma distância recomendável de $5 \mathrm{~mm}$ dos dentes superiores, permitindo a higienização e evitando danos à mucosa palatina ${ }^{47}$. As molas constituem-se no elemento ativo do aparelho e são construídas com fio de titânio-molibdênio (TMA) 0.032" e encaixadas nos tubos linguais dos molares, exercendo forças moderadas e contínuas, já que o fio de TMA permite uma deflexão duas vezes maior que o aço inoxidável previamente à deformação permanente ${ }^{18}$. As molas iniciam-se na porção distal do botão de acrílico, próximas à sutura palatina mediana, sendo adaptadas ao palato, evitando-se traumatismos à língua. As molas possuem um helicóide, que promove a força de distalização, e uma pequena alça horizontal para facilitar os ajustes transversais, uma vez que a distalização tende a cruzar a mordida na medida em que os molares assumem uma posição mais para distal. A denominação do aparelho relaciona-se ao modo de atuação das molas, semelhante a um pêndulo, partindo da linha média do palato em direção aos molares superiores. As molas ainda apresentam dobras de encaixe confeccionadas na outra extremidade do fio de TMA para que as mesmas possam ser devidamente encaixadas nos tubos linguais das bandas dos molares. A porção anterior do aparelho é estabilizada de várias formas. Originalmente, fez-se por meio de apoios oclusais colados nos molares decíduos ou nos primeiros e segundos pré-molares. Porém HILGERS ${ }^{47}$ afirma que o método mais estável de retenção do aparelho consiste na cimentação de bandas nos primeiros pré-molares ou primeiros molares 
decíduos e grampos de apoios oclusais nos segundos pré-molares. Essas extensões podem ser removidas durante o tratamento, para permitir 0 deslocamento natural dos segundos pré-molares para distal ${ }^{47}$. Este deslocamento torna-se possível devido à ação das fibras periodontais interdentárias transeptais, visto que durante a distalização dos molares as fibras existentes entre estes dentes e os pré-molares ou molares decíduos tornam-se estiradas. Como esta tensão não equivale às condições fisiológicas normais, as fibras são submetidas a um processo de reparação e reorganização, restabelecendo o seu grau de estiramento normal e promovendo o fechamento ou uma significante redução dos espaços interproximais recentemente criados $^{47}$. Quando não ocorre esta migração espontânea destes dentes, estes podem ser retraídos com elástico corrente ${ }^{47}$.

Nos casos onde há necessidade de expansão transversal, adaptase um parafuso expansor no acrílico da região mediana do palato, transformando-se no aparelho denominado Pendex (Pendulum + expansor) ${ }^{47}$.

De acordo com HILGERS ${ }^{47}$, o aparelho Pendulum é capaz de promover uma distalização dos molares superiores, de $5 \mathrm{~mm}$ em 3 ou 4 meses. 


\subsubsection{Ativação do aparelho Pendulum}

As molas podem ser ativadas externa ou internamente. HILGERS ${ }^{47}$ recomenda a ativação das molas de TMA externamente, ou seja, previamente à cimentação do aparelho. As molas devem ser ativadas, abrindo-se o helicóide até que o braço da mola esteja paralelo à linha mediana do palato (perpendicular ao corpo do aparelho) ${ }^{2,19-21,47,109}$. À primeira vista, parece uma super-ativação, mas cerca de 1/3 da mesma perde-se na instalação do aparelho e a pressão restante é facilmente suportada pelo paciente. A liga de titânio-molibdênio apresenta o dobro da flexibilidade e a metade do módulo de elasticidade dos fios de aço ${ }^{47}$, desta forma, 1/3 da força é dissipada pelas próprias propriedades físicas deste tipo de liga metálica. Assim, a uma disposição do braço da mola, formando um ângulo de $90^{\circ}$ com relação a sua posição inicial passiva, a força efetivamente liberada corresponde a uma ativação hipotética proveniente de um ângulo de ativação de $60^{\circ}$, o que, em termos numéricos, produz uma força aproximada de 200 a 250 gramas. Após a ativação externa, a cimentação é realizada sem que as molas estejam inseridas nos tubos linguais das bandas dos molares ${ }^{47}$. Somente após a instalação do aparelho (cimentação das bandas e/ou colagem com resina dos grampos de apoio), as molas são devidamente posicionadas com o emprego de um alicate 139 ou Weingart, auxiliados ou não por um fio cordonê $00^{2,47}$. 
BYLOFF; DARENDELILER ${ }^{20}$ relataram a necessidade de uma ou duas reativações, quando a mola foi ativada inicialmente em $45^{\circ}$.

A pressão da mola deve ser checada a cada 3 ou 4 semanas $^{33,47}$. De acordo com HILGERS ${ }^{47}$, se requerida a reativação, insere-se as pontas de um alicate 139 ou Weingart no centro do helicóide empurrandoo distalmente em direção à linha média, sem a necessidade da remoção do aparelho. No entanto, a ativação interna exige maior tolerância do paciente e habilidade do profissional devido ao acesso reduzido, capaz de provocar lesões no palato ${ }^{109}$.

ALMEIDA et al. ${ }^{2}$, em 1999, propuseram modificações na estrutura do aparelho, para que as molas sejam reativadas extrabucalmente, de forma a facilitar sua execução e maximizar o controle da movimentação dos molares, já que evita a incorporação de distorções nas molas. Para isso, os autores sugerem que as molas de TMA sejam removíveis, proporcionando sua fácil remoção do aparelho, ativação extrabucal e nova reinserção, sem a necessidade da remoção de todo o sistema. $O$ aparelho é construído de maneira convencional, porém para a fixação das molas incorpora-se, durante a acrilização do aparelho, duas extensões de $10 \mathrm{~mm}$ de tubos telescópicos de aço inoxidável 0.049 x 0.033" da marca Tecnident (código TT-009) posicionados paralelamente à sutura palatina mediana. Ativa-se as molas extrabucalmente e, após a fixação do aparelho, essas são inseridas nos tubos telescópicos e, posteriormente, nos tubos linguais dos primeiros molares superiores. 
Modificação semelhante foi proposta por SCUZZO et al. ${ }^{98}$, em 2000. Para que as molas de TMA tornem-se removíveis, esses autores sugeriram a confecção de um sistema de encaixe durante a confecção do botão palatino de Nance. As principais vantagens do sistema são: redução do tempo de cadeira, movimentação de $1,5 \mathrm{~mm} / \mathrm{mês}$, melhor controle da força empregada, resultados mais precisos, menor ocorrência de efeitos adversos e conversão do aparelho Pendulum em botão palatino de Nance somente pelo encaixe de fios de aço inoxidável passivos.

Se durante a distalização ocorrer uma mordida cruzada do molar superior, HILGERS ${ }^{47}$ recomenda a abertura da alça horizontal em aproximadamente $15 \%$, promovendo a expansão transversal e a correção da rotação distopalatina indesejada.

\subsubsection{Indicações}

De acordo com HILGERS ${ }^{47}$, MACEDO; IDAR $^{69}$ e RONDEAU ${ }^{89}$ as principais indicações do aparelho Pendulum compreendem:

- comprimento de arco superior deficiente devido a uma perda precoce dos molares decíduos (recuperador de espaço);

- má oclusão de Classe II, com características dentoalveolares;

- distalizações de molares superiores uni ou bilaterais; 
- pacientes não colaboradores;

- pacientes braquifaciais e mesofaciais.

\subsubsection{Contra-indicações}

A maior contra-indicação apontada por HILGERS ${ }^{47}$ diz respeito aos pacientes dolicofaciais, em decorrência da tendência de abertura da mordida anterior promovida pelo uso do aparelho Pendulum. Para estes casos, recomenda o tratamento por meio de extrações, aparelhos extrabucais e barras transpalatinas.

O aumento na altura facial anterior, resultante desta mecanoterapia, foi comprovada por diversos estudos ${ }^{19,25,35,37}$, nos quais os autores também não indicam a utilização do aparelho Pendulum para os casos com dimensão vertical aumentada.

URSI; ALMEIDA ${ }^{109}$ contra-indicam a utilização deste aparelho nos casos de trespasse horizontal aumentado, mordida aberta anterior, ausência de selamento labial, presença de segundos molares irrompidos sem espaço para distalização (presença de terceiros molares) e distância 6-PTV inadequada acompanhada de uma Classe II completa. 


\subsubsection{Efeitos ocasionados pelo aparelho Pendulum}

HILGERS $^{47}$, em 1992, afirmou que o aparelho Pendulum proporciona um movimento distal dos molares superiores de $5 \mathrm{~mm}$, num período de 3 a 4 meses.

Posteriormente, outros autores como GHOSH; NANDA ${ }^{37}$, em 1996 e BYLOFF; DARENDELILER ${ }^{20,21}$, em 1997, realizaram estudos para avaliar os efeitos decorrentes da utilização do aparelho Pendulum ${ }^{37}$ e Pendex $^{20,21}$ em pacientes Classe II, por meio da análise de telerradiografias em norma lateral e modelos iniciais e pós-distalização. Os resultados mostraram que:

- a proporção de distalização compreendeu $1,02 \mathrm{~mm} / \mathrm{mês}^{20}$, sendo que a distalização média dos molares foi de $3,37 \mathrm{~mm}$ no estudo de GHOSH; NANDA $^{37}$ e de $3,39 \mathrm{~mm}$ no de BYLOFF; DARENDELILER ${ }^{20}$;

- a presença dos segundos molares superiores não interferiu na distalização obtida ${ }^{20,37}$;

- a inclinação média para distal do primeiro molar superior foi de $14,5^{\circ}$ no estudo de BYLOFF; DARENDELILER ${ }^{20}$ e de $8,36^{\circ}$ no de GHOSH; NANDA $^{37}$;

- o movimento para mesial dos primeiros pré-molares foi, em média, de 2,55 mm, com uma inclinação mesial de $1,29^{\circ}$ e uma extrusão de 1,7 $\mathrm{mm}^{37}$ 
- o espaço criado deveu-se em $75 \%$ pela distalização dos molares e $25 \%$ pela mesialização dos pré-molares ${ }^{20}$, diferentemente dos dados obtidos por GHOSH; NANDA ${ }^{37}$, em que para cada $1 \mathrm{~mm}$ de distalização ocorreu 0,75 mm de mesialização dos pré-molares;

- houve intrusão dos primeiros molares superiores ${ }^{20}$, porém em outro estudo $^{37}$ essa não foi significativa;

- ocorreu mesialização dos segundos pré-molares de 1,63 mm e extrusão de $0,78 \mathrm{~mm}^{20}$;

- observou-se alterações transversais, representadas pelo aumento na distância entre os primeiros molares superiores em 1,4 mm e entre os segundos molares em 2,33 $\mathrm{mm}^{37}$;

- protrusão do lábio superior em 0,31 mm e do inferior em 0,95 mm

- aumento do trespasse horizontal em 1,3 $\mathrm{mm}^{37}$;

- redução do trespasse vertical em 1,39 $\mathrm{mm}^{37}$;

- vestibularização dos incisivos superiores em $1,71^{0^{20}}$ e $2,4^{037}$;

- os segundos molares, quando presentes, distalizaram, em média, $2,27 \mathrm{~mm}(0,9 \mathrm{~mm}$ a menos que os primeiros molares), inclinaram distalmente $11,99^{\circ}$ e sofreram uma intrusão média de $0,47 \mathrm{~mm}^{37}$.

No estudo realizado por GHOSH; NANDA ${ }^{37}$, os autores observaram efeitos esqueléticos promovidos pelo aparelho Pendulum. O maior efeito ocorreu na AFAl que aumentou 2,79mm em média e 2 vezes mais em pacientes apresentando FMA maior que $24^{\circ}$. O plano mandibular 
inclinou inferiormente, em média, $1,09^{\circ}$, proporcionando a redução do trespasse vertical $(1,39 \mathrm{~mm})$. Os resultados mostraram que o aparelho Pendulum afeta primariamente os dentes e osso alveolar, embora possua efeitos indiretos nas estruturas esqueléticas e tecidos moles. Contrariamente, BYLOFF; DARENDELILER ${ }^{20}$ não determinaram qualquer efeito esquelético no sentido vertical ocasionado pelo aparelho.

Mais recentemente, outros autores investigaram os efeitos provocados pelo tratamento com o aparelho Pendulum. BUSSICK; McNAMARA JR ${ }^{19}$, em 2000, examinaram as alterações dentoesqueléticas ocasionadas pelo Pendulum em 101 pacientes, com idade média de 12 anos e um mês. Os indivíduos foram tratados por 13 diferentes profissionais, sendo que as molas foram ativadas entre $60^{\circ}$ e $90^{\circ}$, produzindo uma força para distal entre 200 a $250 \mathrm{~g}$. As consultas de monitoramento foram mensais, num período de 8 a 12 semanas. As telerradiografias finais foram obtidas quando os molares atingiram a relação molar próxima de Classe III. Os autores atentaram para a presença ou ausência dos segundos molares decíduos e dos segundos molares permanentes irrompidos, além dos diferentes padrões faciais, caracterizados pelo FMA, considerado baixo quando menor que $21^{\circ}$, alto se maior que $26^{\circ}$ e neutro entre $21^{\circ}$ e $26^{\circ}$. Os resultados indicaram que o aparelho Pendulum afeta primariamente o arco dentário superior, com efeitos menos pronunciados sobre as estruturas esqueléticas craniofaciais e tecidos moles. As alterações dentárias observadas foram um aumento do trespasse horizontal, uma diminuição do trespasse vertical e a 
correção da relação molar. A distalização média dos primeiros molares superiores consistiu em 5,7mm, com uma inclinação distal de 10,6 ${ }^{\circ}$. Os dentes da unidade de ancoragem sofreram mesialização de $1,8 \mathrm{~mm}$, sendo que os pré-molares apresentaram inclinação mesial de $1,5^{\circ}$. $O$ espaço obtido deveu-se a distalização dos molares em 76\% e em $24 \%$, devido à mesialização dos pré-molares. A relação molar demonstrou 6,4mm de correção da Classe II. Os primeiros molares superiores intruíram 0,7mm, enquanto que os primeiros pré-molares extruíram $1 \mathrm{~mm}$. Os primeiros molares inferiores extruíram $0,7 \mathrm{~mm}$, com mesialização de $0,2 \mathrm{~mm}$. As alterações verticais mostraram que o plano palatino permaneceu inalterado durante o período. O ângulo do plano mandibular e a AFAl aumentaram significantemente. A mandíbula apresentou rotação horária de $1^{\circ}$, o trespasse vertical diminuiu $1,7 \mathrm{~mm}$ e $\mathrm{o}$ trespasse horizontal aumentou 0,8mm. A AFAl aumentou $2,2 \mathrm{~mm}$ e não houve diferença entre os pacientes com FMA baixo, alto ou neutro. Atribuiu-se esse aumento à extrusão de $0,7 \mathrm{~mm}$ dos molares inferiores associado ao movimento para distal dos molares superiores para dentro do arco de fechamento. Considerando-se a ancoragem proporcionada pelos molares decíduos em relação aos pré-molares, ocorreu uma extrusão maior no último grupo, produzindo maior aumento da AFAl (2,4mm contra 1,6mm). Não houve diferença na quantidade de distalização na presença ou ausência dos segundos molares superiores irrompidos, exceto relacionada a um maior aumento da AFAl, na presença destes. Constatou-se a ocorrência da protrusão do lábio superior de $0,6 \mathrm{~mm}$ e do 
lábio inferior de $1 \mathrm{~mm}$, em relação ao plano estético. O ângulo nasolabial diminuiu $2,5^{\circ}$ e a inclinação do lábio superior acentuou-se em $2^{\circ}$. Essas alterações foram atribuídas à perda de ancoragem anterior. Os autores ${ }^{19}$ afirmaram que o aparelho Pendulum deve ser empregado idealmente na presença dos segundos molares decíduos e na ausência dos segundos molares superiores, para a obtenção da máxima distalização dos molares com o mínimo aumento da AFAl, embora não se tenha constatado abertura significante da mordida.

Em 2000, KIZINGER et al. ${ }^{60}$ avaliaram os efeitos da utilização de um aparelho Pendulum modificado quanto: ao posicionamento das molas de TMA (helicóides o mais distante possível dos molares e o mais próximo possível da sutura palatina mediana), à introdução de um parafuso com abertura em direção distal (no sentido ântero-posterior) e a alterações na técnica de ativação intrabucal. A amostra compôs-se de 50 pacientes com idade média de 11,2 anos. Os resultados obtidos foram os seguintes: $72,5 \%$ do espaço resultou da distalização dos molares, enquanto $27,5 \%$ da mesialização do segmento anterior; os molares demonstraram inclinação para distal de $3,14^{0}$ em relação ao plano palatino e de $3,24^{\circ}$ em relação à base do crânio e extrusão de 0,36 mm, enquanto os incisivos sofreram uma vestibularização de $4,10^{\circ}$ em relação ao plano palatino e de $3,93^{\circ}$ em relação à base do crânio; a média de distalização foi de $0,67 \mathrm{~mm}$ por mês e as alterações foram predominantemente dentoalveolares, sem significantes alterações 
esqueléticas. O tempo médio do uso do aparelho Pendulum foi de 22,5 semanas.

FUZIY ${ }^{35}$, em 2001, avaliou 32 pacientes Classe II, divisão 1, com idade média de 14 anos e 10 meses. Foram analisadas as telerradiografias em norma lateral e em $45^{\circ}$, além dos modelos iniciais e após a distalização promovida pelo aparelho Pendulum. O período médio de tratamento compreendeu 5,85 meses. Os resultados obtidos consistiram em: 1) não houve alterações esqueléticas na maxila e mandíbula, exceto por uma rotação horária mandibular, refletindo no aumento da AFAl, 2) os primeiros molares superiores distalizaram em média 4,83mm, com uma inclinação distal de $\left.12,66^{\circ}, 3\right)$ os segundos molares superiores distalizaram em média 4,84mm, com inclinação distal média de $\left.16,23^{\circ}, 4\right)$ os primeiros pré-molares mesializaram em média $1,87 \mathrm{~mm}$, inclinando mesialmente $2,51^{\circ}, 5$ ) os incisivos centrais superiores movimentaram-se para anterior $1,08 \mathrm{~mm}$, inclinando-se para vestibular $\left.3,40^{\circ}, 6\right)$ aumento do trespasse horizontal em 1,56mm, 7) extrusão dos primeiros molares superiores de 1,52mm, intrusão dos segundos molares superiores de $0,78 \mathrm{~mm}$ e extrusão dos primeiros pré-molares superiores de $1,52 \mathrm{~mm}, 8)$ redução do trespasse vertical em $1,03 \mathrm{~mm}, 9)$ expansão transversal dos primeiros molares em $0,71 \mathrm{~mm}, 10$ ) a taxa de distalização mensal foi de $1,06 \mathrm{~mm}, 11$ ) alterações no perfil facial, com o aumento do ângulo nasolabial de $1,35^{\circ}$ e uma protrusão do lábio superior, em relação à linha $\mathrm{E}$, de $0,29 \mathrm{~mm}$. Como forma de controlar a inclinação dos molares 
superiores, o autor sugere a realização de dobras de anti-inclinação associada à obtenção da sobrecorreção.

Também em 2001, CHAQUÉS-ASENSI; KALRA ${ }^{25}$ analisaram os efeitos do aparelho Pendulum no complexo dentofacial em 26 pacientes, com idade média de 11 anos e 2 meses, possuindo no mínimo uma relação molar de $1 / 2$ Classe II, sendo que em 11 pacientes os segundos molares superiores não haviam irrompido. Os primeiros molares distalizaram 5,3mm, inclinaram para distal $13,1^{\circ}$ e intruíram 1,2mm. Os primeiros pré-molares superiores ou primeiros molares decíduos mesializaram 2,2mm, inclinaram para mesial 4,8 e extruíram 1,2mm. Os incisivos centrais superiores protruíram 2,1mm e sua inclinação aumentou $5,1^{\circ}$ para vestibular. O trespasse horizontal aumentou $1,8 \mathrm{~mm}$ e o vertical diminuiu 1,8mm. A altura facial ântero-inferior aumentou 2,8mm, enquanto que o FMA aumentou 1,3․ O tempo médio de distalização compreendeu 6,5 meses, em uma proporção de $0,8 \mathrm{~mm} / \mathrm{mês}$. A quantidade de distalização apresentou-se independente da presença ou não dos segundos molares superiores, mas a perda de ancoragem caracterizou-se maior em $0,5 \mathrm{~mm}$ com a irrupção dos segundos molares. Os autores contra-indicaram o uso do aparelho Pendulum em pacientes com altura facial ântero-inferior excessiva e/ou mordida aberta.

ANGELIERI $^{4}$, em 2002, avaliou, por meio da cefalometria, a fase de final de nivelamento após a distalização com o aparelho Pendulum em uma amostra composta por 23 pacientes, sendo que 22 destes foram utilizados no presente estudo. Os resultados demonstraram um aumento 
de 0,88 mm na AFAl; extrusão dos incisivos superiores de 0,51 mm; verticalização de $10,23^{0}$ e distalização de $2,86 \mathrm{~mm}$ para os primeiros prémolares superiores; extrusão de 0,73 mm, mesialização de $1,2 \mathrm{~mm}$ e verticalização de $7,63^{0}$ para os primeiros molares superiores.

O primeiro estudo publicado realizado em uma amostra avaliada até o final do tratamento corretivo foi publicado em 2003, por BURKHARDT, McNAMARA JR, BACCETTI ${ }^{17}$. Os autores compararam os efeitos do aparelho Herbst e do aparelho Pendulum após a terapia ortodôntica fixa. Verificaram que não houve diferença no crescimento mandibular entre os dois grupos. O grupo do Pendulum apresentou uma maior distalização dos molares $(5,9 \mathrm{~mm})$ e também uma maior inclinação para distal $\left(10^{\circ}\right)$. Verificaram que durante a fase de aparelho fixo, houve uma considerável recidiva no posicionamento dos molares e pré-molares, onde após o tratamento, os primeiros molares superiores apresentavamse apenas $0,8 \mathrm{~mm}$ para distal em relação ao posicionamento inicial e os primeiros pré-molares retornaram ao posicionamento inicial. Apesar de recidivar $87 \%$ a distalização dos molares em relação à primeira fase do tratamento (uso do Pendulum), a relação molar normal foi mantida e o trespasse horizontal corrigido. Os autores descrevem que a manutenção da relação molar e a correção do trespasse horizontal mesmo com a recidiva da distalização pode ser explicada por um padrão de crescimento favorável (idade inicial do grupo do Pendulum: 12,3 anos) e compensações dentoalveolares (intercuspidação e elástico de Classe II). O Pendulum promoveu um aumento no ângulo do plano mandibular e 
uma rotação horária da mandíbula. O mento dos pacientes tratados com Herbst apresentaram-se mais anteriorizados, justificando a sua indicação para pacientes com retrusão mandibular. O sucesso do tratamento empregando ambos os aparelhos deveu-se substancialmente às alterações dentoalveolares.

TANER et al. ${ }^{105}$, em 2003, compararam os efeitos da distalização entre os aparelhos extrabucal e Pendex. A amostra foi constituída por 26 pacientes, sendo 13 tratados por meio do extrabucal e 13 por meio do Pendex. As alterações foram avaliadas pelo teste não paramétrico de Mann-Whitney. Entre os resultados obtidos verificaram que a quantidade de distalização foi semelhante entre os grupos (3,15 mm para o grupo de extrabucal e $3,81 \mathrm{~mm}$ para o Pendex). Os segundos molares superiores distalizaram 2,27 $\mathrm{mm}$ no grupo tratado com o extrabucal e 2,04 $\mathrm{mm}$ no tratado com o Pendex. O tempo de distalização apresentou-se maior para o grupo do extrabucal $(11,38$ meses) do que o tratado com o Pendex (7,31 meses). A inclinação para a distal foi de $11,04^{0}$ e de $6,96^{0}$ para o Pendex e o extrabucal respectivamente, sendo que a análise estatística não demonstrou alteração significante entre os grupos para esta variável. Os pré-molares foram movimentados para mesial e os incisivos vestibularizaram no grupo do Pendex, enquanto que no do extrabucal os pré-molares acompanharam a distalização. Os autores concluem que a perda de ancoragem com a utilização do aparelho Pendex assim como a necessidade de colaboração e o maior tempo de tratamento no uso do aparelho extrabucal deverão ser considerados durante o planejamento. 
Em 2004, ANGELIERI et al. ${ }^{5}$ escreveram um artigo (no prelo) em que avaliam o tratamento completo com o aparelho Pendulum. Os resultados demonstraram a distalização dos molares, protrusão dos incisivos, mesialização dos pré-molares e aumento da AFAl com o uso do distalizador avaliado. Ao final do tratamento com o aparelho fixo, os incisivos, os pré-molares e os molares retornaram às suas posições originais. Observaram que os primeiros molares superiores, que haviam sido distalizados, em média $2 \mathrm{~mm}$, mesializaram $1,1 \mathrm{~mm}$ durante $\mathrm{o}$ alinhamento e nivelamento e, ao final do tratamento corretivo, apresentaram uma mesialização de 2,1 mm, retornando à posição inicial. Entretanto, a relação molar e o trespasse horizontal apresentaram-se corrigidos quando do término do tratamento. Os autores enfatizam a dificuldade no controle da ancoragem durante a mecanoterapia com o aparelho Pendulum, ressaltando a necessidade do uso efetivo de dispositivos para a manutenção da mesma (aparelho extrabucal noturno associado ao botão palatino de Nance). Concluem que a correção da Classe II ocorreu principalmente devido à compensação dentoalveolar e possivelmente em função do crescimento mandibular. 


\subsubsection{Quantidade de correção da relação molar}

A maioria dos trabalhos recomenda uma sobrecorreção dos molares em uma super Classe I devido à tendência à recidiva, visto que se observa uma inclinação dos molares distalizados $2,4,5,13,17,20,21,25,37,47,89,109$. A inclinação dos molares encontra-se relacionada à recidiva devido à impossibilidade de uma correta distribuição das forças mastigatórias e também à seqüência do tratamento ortodôntico, onde os dentes anteriores são retraídos utilizando-se os molares como ancoragem ${ }^{109}$.

BYLOFF et al. $^{21}$ após observarem uma inclinação para distal excessiva no estudo anteriormente realizado ${ }^{20}$, propuseram-se a avaliar, em 20 pacientes, o grau de inclinação dos molares, realizando o tratamento em duas fases, com uma modificação no aparelho (confecção de dobra de verticalização) com o intuito de tentar minimizar este efeito colateral. Inicialmente, utilizaram o aparelho como descrito por HILGERS ${ }^{47}$, porém ativando a mola de TMA em $45^{\circ}$ e não paralelamente à sutura palatina mediana, até a obtenção de uma sobrecorreção na relação molar. Após esta fase, sugerem a modificação da angulação do encaixe no tubo lingual, confeccionando uma dobra em torno de $10^{\circ}$ a $15^{\circ}$ em direção oclusal. Mantiveram a ativação para distalização para não perder a relação molar obtida e/ou ganho de espaço. O aparelho permaneceu instalado até a verticalização dos molares. Radiografias periapicais, telerradiografias laterais e panorâmicas foram obtidas antes 
da primeira fase e depois da segunda, utilizaram-se ainda da amostra anteriormente estudada ${ }^{20}$ para comparações. $\mathrm{O}$ valor médio de distalização da coroa obtido na primeira fase foi de $1,20 \mathrm{~mm} \pm 0,74 \mathrm{~mm}$ ao mês e, considerando-se o tempo total do experimento, 0,69 $\mathrm{mm} \pm$ 0,29mm ao mês. Os ápices dos molares distalizaram, em média, 1,01mm \pm 0,57mm por mês. Ao compararem o tempo gasto na primeira fase para a obtenção da relação molar normal com o estudo anterior, verificaram ser similares, demonstrando que a força de 200 a 250 gramas utilizadas pode corrigir a Classe II em aproximadamente 4 meses, porém foram necessárias, em média, mais 10,9 semanas para a verticalização dos molares, totalizando $27,25 \pm 7,12$ semanas de tratamento, o que resultou em um aumento no tempo de tratamento de aproximadamente $64,1 \%$. Houve uma diminuição na inclinação para distal dos molares de $14^{\circ}$ para $6^{\circ}$. Verificou-se um maior movimento de corpo em relação ao estudo anterior. Visto que durante a verticalização, as forças de distalização ainda encontravam-se presentes e houve um aumento no tempo de tratamento, os autores verificaram uma maior movimentação distal dos molares, mesialização e inclinação dos incisivos e um aumento da perda de ancoragem dos pré-molares. Descrevem que a incorporação das dobras de verticalização facilita o tratamento com o aparelho fixo, com maior movimentação de corpo dos molares, esperando-se menor perda de ancoragem.

A preocupação em relação à instabilidade do movimento de inclinação dos molares após a distalização com o aparelho Pendulum 
levou SCUZZO; PISANI; TAKEMOTO ${ }^{97}$, em 1999, a proporem uma modificação no aparelho a fim de assegurar o movimento de corpo destes dentes. A modificação proposta é simples, obtida apenas pela inversão da alça horizontal, que fica voltada para mesial dos primeiros molares superiores. Denominaram este aparelho modificado de M-Pendulum. Após a distalização dos molares, os autores indicam a ativação da alça simplesmente por meio da sua abertura.

\subsubsection{Presença dos segundos molares superiores}

Ao propor na literatura o aparelho Pendulum, HILGERS ${ }^{47}$ descreve que a distalização parece ser mais eficiente previamente ao irrompimento dos segundos molares superiores. No entanto, ressalta que esta pode ser obtida mesmo quando estes dentes já se encontram erupcionados. Sugere ainda que nos casos onde necessite-se de uma acentuada distalização e as extrações dos pré-molares não estejam indicadas devese remover os segundos molares superiores, realizar a distalização dos primeiros molares por meio do aparelho Pendulum e deixar que os terceiros molares irrompam.

Dos 41 pacientes avaliados por GHOSH; NANDA ${ }^{37}, 18$ apresentavam os segundos molares irrompidos e 23 não. Ao compararem os efeitos da distalização entre estes dois grupos, verificaram que os 
segundos molares, quando presentes, distalizaram, em média, 2,27mm $\left(0,9 \mathrm{~mm}\right.$ a menos que os primeiros molares), inclinaram distalmente $11,99^{0}$ e sofreram uma intrusão média de $0,47 \mathrm{~mm}$. Os resultados indicaram que a erupção dos segundos molares tem mínimos efeitos sobre a distalização dos primeiros molares.

BYLOFF; DARENDELILER ${ }^{20,21}$ não observaram diferenças estatisticamente significantes quanto aos movimentos de distalização e inclinação na presença ou ausência dos segundos molares.

Em relação à necessidade de extrações dos terceiros molares, previamente à instalação do aparelho Pendulum, SCUZZO; PISANI; TAKEMOTO $^{97}$ indicam a avaliação da distância entre o primeiro molar superior ao plano vertical pterigóide de Ricketts. Normalmente esta distância corresponde à idade do paciente $\pm 3 \mathrm{~mm}$.

BUSSICK; McNAMARA JR ${ }^{19}$ também não observaram diferença na quantidade de distalização na presença ou ausência dos segundos molares superiores irrompidos, exceto relacionada a um maior aumento da AFAI, na presença destes.

No estudo de CHAQUÉS-ASENSI; KALRA ${ }^{25}$, em 2001, os autores verificaram que a quantidade de distalização apresentou-se independente da presença ou não dos segundos molares superiores, mas a perda de ancoragem caracterizou-se maior em $0,5 \mathrm{~mm}$ com a irrupção destes dentes. 
KINZINGER et al. ${ }^{59}$, em 2004, investigaram a influência da presença dos germes dos segundos e terceiros molares ou do segundos molares já irrompidos na inclinação dos primeiros molares superiores distalizados por meio do aparelho Pendulum. Observaram que o germe do segundo molar agiu como um fulcro para o primeiro molar superior, levando a uma inclinação para distal da coroa bem maior comparado ao grupo com segundo molar irrompido. O maior movimento distal de corpo foi obtido com o segundo molar superior já irrompido e a germectomia do terceiro molar, apesar do tempo de tratamento ser maior, maiores forças serem empregadas e ocorrer maior perda de ancoragem.

\subsubsection{Contenção dos primeiros molares permanentes após a distalização}

Após a distalização, torna-se necessário manter o posicionamento do molar. Para isto, HILGERS ${ }^{47}$ propõe a utilização de um dos seguintes métodos: arco utilidade, arco contínuo com ômegas justos e amarrados, aparelho extrabucal ou pela utilização de um botão palatino de Nance instalado em uma única sessão, imediatamente após a remoção do aparelho Pendulum.

O arco utilidade, preferencialmente retangular, e o arco contínuo com ômega amarrado mantêm o comprimento do arco superior 
estabelecido pela nova posição dos molares distalizados, possibilitando a movimentação dos pré-molares ou molares decíduos para distal ${ }^{109}$.

O aparelho extrabucal constitui-se em outra opção de contenção para os molares. Apesar de requerer a colaboração do paciente, seria utilizado por um menor espaço de tempo em comparação ao que seria necessário caso toda a distalização dos molares tivesse que ser obtida com este tipo de aparelho ${ }^{13,47,109}$. BORTOLOZO et al. ${ }^{13}$ recomendam a utilização do aparelho extrabucal tipo Kloehn durante à noite e de elásticos de Classe II durante o dia enquanto os segmentos anteriores são distalizados.

A instalação imediata de um botão palatino de Nance após a remoção do distalizador constitui-se em outra alternativa. Este dispositivo deve ser confeccionado com fio 0.032 " ou 0.036 " de diâmetro que são inseridos nos tubos linguais, da mesma forma que as barras transpalatinas, possuindo ainda dobras retentivas para a resina, na porção anterior ${ }^{47,109}$. O botão deverá ser removido durante a retração anterior, permanecendo na cavidade bucal somente até que os prémolares superiores ou os molares decíduos tenham sido distalizados. 


\subsubsection{Pendulum $X$ tempo de tratamento}

Na literatura, a maioria dos trabalhos publicados ${ }^{19,20,25,35,37,60,73}$ avaliam apenas a fase de distalização. Considerando-se apenas esta fase, a maioria dos estudos demonstram um tempo médio de tratamento de 3 a 5 meses $^{19,20,37,47}$.

WONG; RABIE; HÄGG ${ }^{113}$, em 1999, descrevem um caso clínico onde o tempo total de tratamento foi de 24 meses. A paciente possuía 13 anos de idade, Classe II, $2^{\underline{a}}$ divisão completa e apinhamento superior de $6 \mathrm{~mm}$. O tratamento foi realizado por meio das extrações dos segundos molares superiores seguidas da distalização dos primeiros molares com o aparelho Pendulum, que ocorreu num período de 6 meses. Após a obtenção da relação molar normal, o aparelho Pendulum foi mantido como contenção por 4 meses, seguido pela instalação do aparelho ortodôntico fixo para alinhamento e nivelamento dentários. Os autores relatam que as extrações dos segundos molares superiores foram realizadas para possibilitar a correção da inclinação dos incisivos superiores sem alterações no perfil da paciente, para a obtenção do espaço necessário para a correção do apinhamento e para que o caso fosse finalizado com os caninos e molares em relação de normalidade.

Ao avaliar a fase de final de nivelamento após o uso do aparelho Pendulum, ANGELIERI $^{4}$ relata que em muitos pacientes, devido a um apinhamento anterior superior mais severo, acentuado pela perda de 
ancoragem ocorrida durante o tratamento com o Pendulum, foi necessário um maior tempo para o alinhamento e nivelamento dentário (em média 1 ano). Ressalta que ocorrências clínicas como caninos superiores em inframesiovestibuloversão e a grande variação da severidade dos apinhamentos anteriores superiores levaram a uma diversidade do tempo decorrido para a finalização da fase de nivelamento.

No primeiro estudo sobre o tratamento completo com o aparelho Pendulum publicado por BURKHARDT; McNAMARA JR; BACCETTI ${ }^{17}$, o tempo total de tratamento para o grupo do Pendulum foi de 31,6 meses. Os autores não descrevem o quanto duraram a primeira e a segunda fase, relatando apenas o tempo total do tratamento.

\subsubsection{Efeitos colaterais dos distalizadores intrabucais}

A eficácia do aparelho Pendulum na distalização dos molares superiores foi comprovada em diversos estudos ${ }^{19,20,25,35,37,60}$, porém efeitos adversos nos incisivos, caninos e pré-molares superiores, aumento do trespasse horizontal, aumento da altura facial anterior e a inclinação distal da coroa dos molares foram observados. Na literatura, posteriormente ao uso do Pendulum, para a obtenção da distalização das raízes dos molares e para a retração anterior, recomenda-se a utilização de um aparelho extrabucal ${ }^{5,19,37,38,40}$. Durante a retração anterior, também 
se indica o uso de elásticos de Classe ${ }^{1{ }^{19,25}}$. Se esta foi a opção de tratamento em função da não colaboração do paciente, nesta fase, onde ela se torna imprescindível para a obtenção dos melhores resultados, a eficiência do tratamento poderá ser comprometida.

BRYK; WHITE ${ }^{15}$, em 2001, ao apresentarem as opções de tratamento para a correção da Classe II por meio de extrações dentárias, alertam que na utilização dos distalizadores, durante a retração anterior torna-se difícil manter o posicionamento dos molares distalizados.

ANGELIERI et al. ${ }^{5}$, em 2004, ao avaliarem o tratamento completo com o aparelho Pendulum, observaram que os primeiros molares superiores, ao final do tratamento corretivo, apresentaram uma mesialização de 2,1 mm, retornando à posição inicial. Os autores enfatizam a dificuldade no controle da ancoragem durante a mecanoterapia com o aparelho Pendulum, ressaltando a necessidade do uso efetivo de dispositivos para a manutenção da mesma (aparelho extrabucal noturno associado ao botão palatino de Nance).

\subsection{Extrações de dois pré-molares superiores}

As extrações na prática ortodôntica têm sido amplamente discutidas desde o século XIX. 
De acordo com Angle, as extrações dentárias não deveriam ser realizadas para a correção dos problemas ortodônticos, pois, na sua opinião, uma "oclusão normal" somente poderia ser obtida na presença de todos os dentes. Professava o conceito de desenvolvimento funcional, onde os dentes deveriam ser movimentados em direção às suas corretas posições (alinhados, nivelados e articulados entre si) para que a função estimulasse um crescimento suficiente das bases ósseas para as suas acomodações. Esta filosofia expansionista de Angle visava uma estética facial e dentária, saúde periodontal, função ideal e estabilidade ${ }^{95}$.

$\mathrm{CASE}^{24}$ opunha-se à filosofia não extracionista de Angle, alegando que apesar de muitas más oclusões poderem ser tratadas sem a realização de extrações, a estabilidade dos casos apresentava-se muitas vezes comprometida. Para o autor, não é possível manter todos os dentes na boca durante o tratamento de alguns tipos de más oclusões.

O descontentamento com os resultados obtidos no tratamento ortodôntico (biprotrusões e perfis faciais antiestéticos) por meio dos princípios básicos da técnica de arco de canto proposta por Angle, levou TWEED ${ }^{108}$, um discípulo de Angle, a propor a realização de extrações dos quatro primeiros pré-molares, preconizando o preparo de ancoragem, modificando totalmente os princípios da mecânica extracionista.

Em 1963, KESSEL ${ }^{58}$ já afirmava que tanto ele quanto muitos outros ortodontistas realizavam as extrações de dois pré-molares superiores no tratamento da má oclusão de Classe II, obtendo-se, por meio deste protocolo de tratamento, a retração anterior superior, com os caninos 
finalizando em relação normal e os molares em Classe II. O autor afirmou que desde que não ocorram contatos prematuros ou interferências oclusais, não há maiores preocupações em finalizar os casos com os molares em Classe II. Ressaltou ainda que há um grande número de portadores desta má oclusão não submetidos ao tratamento ortodôntico e que apresentam condições periodontais de normalidade. Apresentou, no final do seu artigo, dois casos clínicos tratados com sucesso por meio deste protocolo. O autor também descreveu que a necessidade de ancoragem é menor e que é permitido, e muitas vezes desejável, uma suave rotação mesiolingual dos molares superiores, de modo que a cúspide mesiovestibular do primeiro molar superior oclua na vertente distal da cúspide vestibular do segundo pré-molar inferior, auxiliando a estabilidade do caso.

$\mathrm{CASE}^{24}$ advogava que na realização das extrações de dois prémolares superiores, os dentes que necessitam de maior movimentação são os seis anteriores que são retraídos para o fechamento dos espaços, restabelecendo a harmonia facial. Afirmou ainda que o posicionamento dentário obtido possibilita uma função mastigatória normal e que as novas posições dentárias são facilmente contidas.

Ao descrever sobre as extrações de dois pré-molares no tratamento da Classe II, GRABER ${ }^{42}$ relatou que por meio deste protocolo observa-se uma redução da protrusão maxilar, a eliminação do trespasse horizontal e o restabelecimento de uma atividade normal da musculatura peribucal. Ressaltou que a movimentação radicular apresenta-se menos 
onerosa em relação ao tratamento com as extrações de quatro prémolares e que, freqüentemente, a correção é obtida em um tempo de tratamento relativamente curto.

DeANGELIS ${ }^{30}$, em 1973, enfatizou que na seleção dos dentes a serem extraídos deve-se considerar que a correção é facilitada pela extração dos dentes mais próximos aos que se encontram mal posicionados. Afirmou que as extrações de dois pré-molares superiores apresentam bons resultados no tratamento da Classe II e o fato de os molares finalizarem em relação de Classe II não ocasiona problemas funcionais.

A decisão entre extrair ou não dentes pode, de acordo com VIG et al. ${ }^{110}$ influenciar o resultado do tratamento ortodôntico em relação ao perfil facial, a estética, a oclusão, a satisfação do paciente e também a duração do tratamento. Em 1990, os autores avaliaram a possível existência de um relacionamento entre a freqüência de extrações e a duração do tratamento. A amostra utilizada, composta por 438 pacientes oriundos de 5 clínicas diferentes, apresentou freqüência média de extrações de 54\%, com variação de 25 a 84\%. O tempo de tratamento foi influenciado pelo número de arcos tratados, pelo número de fases e pela execução ou não de extrações. $\mathrm{Na}$ avaliação de cada clínica isoladamente, os casos sem extrações apresentaram uma menor duração de tratamento, redução esta que variou entre 2,3 a 7,4 meses.

Alguns trabalhos ${ }^{83,110}$ ressaltaram que os ortodontistas norteiam suas decisões baseados em linhas de conduta extracionista ou não 
extracionista, experiências passadas e considerações subjetivas, não se utilizando de critérios científicos na determinação da necessidade de extrações dentárias.

JANSON et al. ${ }^{52}$, em 2003, ao compararem as alterações oclusais promovidas pelos protocolos de extrações de três e quatro pré-molares no tratamento da Classe II, subdivisão, observaram que quando o plano de tratamento não envolve alterações no relacionamento ântero-posterior dos segmentos posteriores, o prognóstico para a correção da má oclusão é melhor, uma vez que a correção da relação molar requer a colaboração do paciente na utilização do aparelho extrabucal e de elásticos intermaxilares.

Ao avaliar a influência da cooperação no planejamento e tempo de tratamento da má oclusão de Classe II, MARIA et al. ${ }^{71}$ afirmaram que as extrações de apenas dois pré-molares superiores facilita enormemente a correção sagital da Classe II. Ressaltaram que para a distalização bilateral dos segmentos posteriores necessita-se de uma maior demanda mecânica e principalmente uma maior colaboração do paciente para se obter sucesso no tratamento. 


\subsubsection{Indicações}

As extrações de dois pré-molares superiores apresentam-se especialmente indicadas para os casos com discrepâncias sagitais superiores, onde os arcos inferiores se apresentem normais ou ao menos próximos à normalidade $\mathrm{e}^{14,41,42,61,68,96}$.

$\operatorname{KESSEL}^{58}$, em 1963, indicava as extrações de dois pré-molares superiores para a correção da Classe II em pacientes a partir dos 12 anos de idade, onde o potencial de crescimento tende a diminuir progressivamente. Este protocolo estaria indicado nos casos com moderada discrepância esquelética, reduzida quantidade de apinhamento inferior, protrusão dos incisivos superiores e variável quantidade de trespasse vertical. O autor discorreu sobre as seguintes vantagens das extrações de dois pré-molares superiores: restabelecimento da harmonia e do equilíbrio facial por meio da retração dos dentes anteriores superiores; correções dos trespasses horizontal e vertical; menor esforço sobre as unidades de ancoragem posterior; maior favorecimento à erupção dos segundos e terceiros molares superiores e menor necessidade de uso de elásticos de Classe II, reduzindo a aplicação de forças e movimentações no arco inferior.

Ao discorrer sobre as extrações na Classe II, $\mathrm{CASE}^{24}$ as indicavam para os casos com protrusão superior acompanhada de uma mandíbula bem posicionada ou mesmo retruída. Enfatizou que as extrações devem 
ser realizadas quando se objetiva a obtenção de um perfil facial harmônico. Nos casos onde os dentes inferiores apresentam-se retruídos e os superiores bem posicionados ou levemente vestibularizados, o autor contra-indicou as extrações.

GRABER ${ }^{41}$, em 1969, indicou a realização das extrações dos dois primeiros pré-molares superiores ou a distalização de molares nos casos onde o paciente não apresenta mais crescimento e possui um bom arco inferior. Ressaltou que a interpretação cefalométrica não deveria ser considerada tão à risca, podendo-se evitar a realização de extrações inferiores, aceitando-se uma posição dos incisivos inferiores um pouco mais anteriorizada.

Para DeANGELIS ${ }^{30}$ as extrações de dois pré-molares superiores estão indicadas nas más oclusões de Classe II onde os segundos molares encontram-se irrompidos, o crescimento cessado, não se observam alterações significantes no posicionamento dentário inferior e os dentes superiores encontram-se protruídos e/ou apinhados.

De acordo com BAUMRIND et al. $^{8}$, os fatores indicadores da necessidade de extrações dentárias no tratamento da má oclusão de Classe II baseiam-se na sua severidade, no reduzido potencial de crescimento frente à magnitude da discrepância ântero-posterior, na falta de cooperação do paciente, na preocupação com o perfil facial e no padrão de crescimento entre outros fatores. Os autores realizaram um estudo onde cinco ortodontistas avaliaram 72 documentações ortodônticas, estabelecendo os planejamentos com ou sem extrações, 
justificando as suas decisões. As quatro razões mais freqüentes na determinação das extrações foram: a quantidade de apinhamento dentário, a protrusão dos incisivos, a necessidade de correção do perfil facial e a severidade da má oclusão de Classe II. O julgamento antecipado da falta de colaboração do paciente e o reduzido ou ausente potencial de crescimento do paciente, embora não estivessem entre os itens mais citados, constituíram-se em fatores de agravamento dos casos.

BRYK; WHITE ${ }^{15}$ ao discutirem as extrações dentárias na correção da má oclusão de Classe II, indicaram as exodontias dos pré-molares superiores, principalmente nos casos onde o crescimento tenha cessado. Alegaram que o protocolo com as extrações apenas superiores facilita a mecânica, promove bons resultados na oclusão e não prolonga o tratamento. Para os autores, as extrações de dois pré-molares superiores possibilitam a obtenção de uma relação normal de caninos e uma boa intercuspidação dos dentes posteriores, além de eliminarem a necessidade de distalização dos molares superiores.

\subsubsection{Estudos concernentes às extrações de dois pré-molares superiores}

Quando se opta por este protocolo de tratamento, a retração dos dentes anteriores superiores reduz o trespasse horizontal, corrigindo a 
relação de caninos e os casos finalizam com os molares em relação de Classe $\|^{15,30,42,51,58,94}$.

No tratamento da má oclusão de Classe II completa com extrações de dois pré-molares superiores, torna-se necessário o uso de reforço de ancoragem para evitar a mesialização dos molares durante a retração dos dentes anteriores. Normalmente, os aparelhos que propiciam este reforço de ancoragem são os extrabucais e, portanto, requerem a colaboração dos pacientes para o sucesso do tratamento ${ }^{51}$.

O tratamento da Classe II sem extrações normalmente requer a colaboração do paciente, seja para a distalização do molar (aparelho extrabucal) ou para distalização das raízes dos molares após o uso dos distalizadores intrabucais. WHEELER et al. ${ }^{112}$ descrevem que o grau de severidade da má oclusão e de cooperação do paciente constituem-se em parâmetros eficientes para predizer a correção da relação molar. KESSEL ${ }^{58}$, BRYK; WHITE ${ }^{15}$, JANSON et al. ${ }^{51}$ e BARROS ${ }^{7}$ concordam que as extrações de pré-molares superiores mantendo a relação molar inicial constitui-se em uma forma de tratamento bastante eficiente e de menor necessidade de cooperação por parte do paciente. PROFFIT ${ }^{81}$ descreveu que os resultados oclusais e estéticos obtidos com este protocolo de tratamento são normalmente satisfatórios, mesmo quando o crescimento residual não contribui significativamente para o tratamento.

Ao comparar os resultados oclusais do tratamento da má oclusão de Classe II realizado por meio das extrações de dois e quatro prémolares, BRAMBILLA ${ }^{14}$ observou uma maior proporção de sucesso nos 
casos tratados com apenas duas exodontias. As extrações de dois prémolares superiores apresentaram resultados mais satisfatórios em relação ao valor final do IPT, ao relacionamento ântero-posterior final dos caninos e às quantidades finais de trespasses vertical e horizontal. Ressaltou ainda que as extrações de dois pré-molares superiores requer uma menor colaboração do paciente na utilização de reforços de ancoragem. Este estudo foi publicado por JANSON et al. ${ }^{51}$ em 2004 na American Journal of Orthodontics and Dentofacial Orthopedics.

GRACIANO $^{44}$, em 2003, comparou as características oclusais e cefalométricas iniciais dos casos bem finalizados tratados por meio das extrações de dois pré-molares superiores e sem extrações (aparelho extrabucal, elásticos de Classe II, aparelho funcional). Observou que os tratamentos realizados com sucesso sem extrações dentárias apresentavam uma suave discrepância ântero-posterior, enquanto que os casos com maior severidade foram tratados com êxito pelo protocolo de extrações de dois pré-molares superiores. Os pacientes tratados com as extrações de dois pré-molares superiores apresentaram maiores valores para o IPT inicial, trespasse horizontal, discrepância ântero-posterior entre as bases ósseas e entre os molares e também para a protrusão dos incisivos superiores.

Ao avaliarem os resultados oclusais no tratamento com três ou quatro extrações de pré-molares da Classe II, subdivisão, JANSON et al. ${ }^{52}$ observaram que os melhores resultados foram obtidos no tratamento com o protocolo de três extrações. Este achado relaciona-se ao fato de 
que a manutenção da relação molar presente ao início do tratamento facilita a correção da má oclusão, diminuindo a necessidade de colaboração do paciente

O tempo de tratamento com extrações de dois pré-molares superiores foi comparado ao protocolo com extrações de quatro prémolares por MARIA ${ }^{70}$, em 2003. O grupo tratado com apenas duas exodontias apresentou melhores resultados oclusais em um tempo despendido de tratamento significantemente menor do que o tratado com quatro.

BARROS $^{7}$, em 2004, comparou o grau de eficiência do tratamento da Classe II completa realizado sem extrações (aparelho funcional, extrabucal ou elástico de Classe II) e com extrações de dois pré-molares superiores. Para isto, avaliou os resultados oclusais por meio dos índices IPT e PAR e também o tempo de tratamento, determinando o índice de eficiência de cada um dos protocolos de tratamento. Observou que o grupo tratado com extrações de dois pré-molares superiores apresentou melhores resultados oclusais, num menor tempo de tratamento e, portanto, um maior grau de eficiência do que o protocolo sem extrações.

Com o propósito de comparar as características iniciais e finais e as alterações cefalométricas dos casos de Classe II completa, tratados com as extrações de dois ou quatro pré-molares, JANSON ${ }^{53}$, em 2004, avaliou uma amostra de 98 pacientes, divididos em dois grupos de acordo com o protocolo de tratamento. O grupo com extrações de quatro prémolares apresentou um menor comprimento das bases apicais, padrão 
facial mais vertical e perfis ósseo e tegumentar mais convexos. O relacionamento ântero-posterior interdentário (trespasse horizontal e relação canino) obtido apresentou-se melhor no grupo com extrações de dois pré-molares.

Em trabalho publicado em 2005, MARIA et al. ${ }^{71}$ compararam a influência da colaboração no planejamento e no tempo de tratamento da má oclusão de Classe II. Para isto, avaliaram 73 pacientes portadores da má oclusão de Classe II completa bilateralmente, divididos em dois grupos de acordo com o protocolo de tratamento: com extrações de dois pré-molares superiores e pacientes planejados inicialmente sem extrações e posteriormente replanejados com exodontias de dois prémolares superiores. O grupo tratado inicialmente sem extrações necessitou de uma colaboração significantemente maior durante 0 tratamento, sendo que a necessidade de replanejamento prolongou significantemente o tempo de tratamento.

\subsubsection{Extrações dentárias $X$ tempo de tratamento}

Alguns trabalhos relataram um aumento no tempo de tratamento relacionado à realização de extrações dentárias ${ }^{26,34,48,78,107,110}$. Entretanto, estudos demonstraram que as más oclusões de Classe II tratadas com extrações apresentam um maior grau de discrepância ântero- 
posterior $^{11,44,48,78,107}$. Sendo assim, a correção de uma má oclusão mais severa encontra-se relacionada a um maior tempo de tratamento $44,90,107,110$ e não necessariamente às realizações de extrações.

Considerando que a predição acurada do tempo de tratamento é extremamente importante na prática ortodôntica, SHIA ${ }^{101}$, em 1986, publicou um estudo onde analisou 500 casos tratados consecutivamente por ele a fim de avaliar o tempo real dos tratamentos em relação ao tempo inicialmente estimado. Verificou que mais de $50 \%$ de seus pacientes necessitaram de mais tempo que o estimado, aproximadamente, 3 meses de acréscimo, e que os pacientes que apresentaram seus tempos de tratamento verdadeiramente extrapolados demonstraram um acréscimo na duração de 25\%. A falta de cooperação foi o fator contribuinte mais importante sendo que a necessidade de replanejamento, principalmente nos casos "borderline" também foi citada pelo autor, sendo responsável por um acréscimo entre 12 e 24 meses.

Em relação ao tempo de tratamento da Classe II, ALEXANDER; SINCLAIR; GOATES ${ }^{1}$ afirmaram que este encontra-se relacionado à severidade da má oclusão e também ao grau de colaboração do paciente.

FINK; SMITH ${ }^{34}$, em 1992, afirmaram que o número de extrações de pré-molares apresenta uma relação direta com o tempo de tratamento. Os autores avaliaram 118 pacientes, tratados em seis diferentes clínicas ortodônticas, sendo que 38\% foram submetidos a extrações e 32\% utilizaram aparelho extrabucal. A média do tempo de tratamento para a amostra total foi de 23,1 meses, sendo que a mais importante variável 
relacionada a diferenças de duração do tratamento entre os casos foi as extrações de pré-molares. O grupo sem extrações apresentou média de 21,95 meses; o grupo com extrações superiores, 25 meses e o grupo com extrações de quatro pré-molares, 26,18 meses. Evidenciaram que o tempo de tratamento é aumentado em 0,9 mês para cada pré-molar extraído.

O'BRIEN et al. ${ }^{78}$ avaliaram, em 1995, a eficiência do tratamento da Classe II, $1^{\underline{a}}$ divisão. Consideraram a porcentagem de alteração do índice PAR e a duração do tratamento. A amostra constituiu-se de 250 pacientes com má oclusão de Classe II tratados no departamento de ortodontia da Universidade de Pittsburgh. Utilizaram a análise de regressão múltipla para avaliar os resultados. As variáveis que apresentaram uma associação significante com a duração do tratamento foram o valor inicial do PAR, o número de estágios do tratamento, a porcentagem de consultas, o número de reparos no aparelho e o fato dos casos terem ou não sido submetidos às extrações dentárias. Em relação ao fato das extrações terem aumentado o tempo de tratamento, os autores enfatizaram que a má oclusão inicial apresentava-se mais severa para este grupo. A única variável que influenciou a porcentagem de alteração do índice PAR foi o seu valor ao início do tratamento.

Ao avaliarem os resultados do tratamento ortodôntico por meio do índice PAR de 200 pacientes (sem distinção entre Classe I, II ou III), sendo 100 tratados com extrações e 100 sem extrações, HOLMAN et al. ${ }^{48}$, em 1998, observaram que o tempo de tratamento foi maior para o 
grupo com extrações (em média 3,7 meses). Os valores iniciais do índice PAR, da quantidade de apinhamento anterior superior e do trespasse horizontal apresentaram-se maiores para o grupo tratado com extrações do que para o tratado sem extrações.

BRAMBILLA $^{14}$ e BARROS ${ }^{7}$ utilizaram a análise de ANDREWS $^{3}$ para ilustrar a efetividade da correção da má oclusão de Classe II por meio das extrações de dois pré-molares superiores. De acordo com ANDREWS ${ }^{3}$, para cada milímetro de discrepância são necessárias 2 U.E. (unidades de espaço) para correção. Como a má oclusão de Classe II completa apresenta 7 milímetros de discrepância de cada lado, num total de 14 milímetros, para a sua correção tornam-se necessárias 28 U.E. Ao extrair dois pré-molares superiores obtém-se, em média, 14 milímetros de espaço ou 14 U.E. (7 de cada lado), sem a necessidade de qualquer colaboração do paciente com uso de aparelhos ${ }^{7}$. Desta forma, restam 14 U.E. a serem obtidas com o auxílio da ancoragem e do crescimento, caso ainda exista potencial ${ }^{7}$. Considerando-se este mesmo raciocínio para o tratamento da Classe II completa sem extrações, as 28 U.E. necessárias à correção deverão ser obtidas integralmente com o auxílio do crescimento e do uso de aparelho que disponibilizem estas unidades de espaço (AEB e elásticos de Classe II), necessitando-se de uma maior colaboração do paciente para o sucesso do tratamento ${ }^{7}$. Nos casos onde não há expectativa de crescimento, a correção da má oclusão de Classe II, sem extrações, torna-se ainda mais difícil e vinculada à cooperação do paciente $^{7}$. Desta forma, BARROS ${ }^{7}$ adverte que o tratamento da má 
oclusão de Classe II completa com extrações de dois pré-molares superiores difere do protocolo de tratamento sem extrações não apenas no tocante à realização ou não de extrações, mas sobretudo no que diz respeito à redução pela metade da necessidade de colaboração do paciente durante o tratamento.

\section{3 Índices oclusais}

Os índices oclusais constituem-se em métodos quantitativos desenvolvidos inicialmente com a finalidade de mensurar a severidade das más oclusões. Estes métodos de avaliação surgiram a partir da década de 50.

Os índices oclusais podem ser utilizados para determinar o acesso à assistência pública na área ortodôntica (são amplamente utilizados com esta finalidade nos Estados Unidos e na Europa) e também na realização de pesquisas ${ }^{100}$, com a finalidade de demonstrar o grau de severidade inicial da má oclusão, avaliação dos resultados, complexidade e também a necessidade do tratamento, além de permitir a avaliação da quantidade de melhora resultante do tratamento encetado.

Os índices oclusais devem, de acordo com SHAW et al. ${ }^{99}$, cumprir alguns requisitos importantes tais como fácil aplicação, boa reprodutibilidade, sensibilidade às alterações oclusais para melhor ou 
pior, mínimo grau de subjetividade para aplicação, confiabilidade e validade para o fim a que se propõe.

SHAW; RICHMOND; O'BRIEN ${ }^{100}$ descrevem que os índices oclusais auxiliam na distribuição dos recursos destinados ao atendimento público; na verificação e padronização dos tratamentos ortodônticos; na identificação das más oclusões que necessitam de tratamento e no consentimento por escrito do paciente nos casos em que a relação custo/benefício é desfavorável. Segundo os autores, os índices oclusais INTO (Índice da necessidade de tratamento ortodôntico) e PAR apresentam um satisfatório desempenho das funções acima citadas.

\subsection{1 Índice de Prioridade deTratamento (IPT) ${ }^{45}$}

Em 1967, GRAINGER ${ }^{45}$ desenvolveu, no Burlington Orthodontic Research Center, o índice de prioridade de tratamento (IPT). Este índice foi proposto inicialmente com a finalidade de determinar se o tratamento ortodôntico reduzia a severidade da má oclusão abaixo do nível de significância utilizado na saúde pública, ou seja, para avaliar o grau de melhora do tratamento ortodôntico. Este índice avalia as seguintes características oclusais: a oclusão no segmento posterior; o relacionamento dos incisivos no sentido ântero-posterior (trespasse horizontal); o relacionamento vertical entre os incisivos (trespasse 
vertical); os deslocamentos dentários relacionados às rotações e ao apinhamento e a ocorrência de mordida cruzada.

LEWIS et al. ${ }^{66}$, utilizaram, em 1982, o IPT com a finalidade de determinar a confiabilidade e a validade dos julgamentos clínicos das más oclusões, incluindo avaliações gerais do padrão oclusal e aspectos mais específicos de más relações dentofaciais. Verificaram que as avaliações clínicas das severidades das más oclusões são comparáveis às mensurações objetivas do IPT em termos de confiabilidade.

Apesar de ser idealizado para a avaliação do grau de melhora do tratamento ortodôntico, GHAFARI; LOCKE; BENTLEY ${ }^{36}$ indicaram a sua utilização como indicador epidemiológico de má oclusão.

Vários trabalhos publicados ${ }^{7,14,44,51,52,70}$ utilizaram o IPT como indicador da presença e severidade da má oclusão e também para a avaliação da eficácia e da eficiência do tratamento ortodôntico.

\subsubsection{Peer Assessment Rating (PAR)}

O índice PAR (Peer Assessment Rating) foi desenvolvido na Inglaterra, em 1987, por um grupo de dez ortodontistas britânicos, com a finalidade de fornecer um único valor para todas as anormalidades oclusais que podem ser observadas em uma mesma má oclusão. Apesar 
de ter sido criado em 1987, somente foi apresentado por RICHMOND et al. $^{85}$ em 1992. De acordo com os autores, o índice PAR preenche os requisitos acima descritos por SHAW et al. ${ }^{99}$ e oferece uniformidade e padronização na avaliação dos resultados do tratamento ortodôntico. A sua validade e reprodutibilidade já foram comprovadas em pesquisas anteriores ${ }^{31,86}$.

Os resultados dos tratamentos são avaliados a partir da diferença calculada entre os valores dos índices obtidos nas fases pré e póstratamento, sendo que o valor numérico desta diferença apresenta-se inversamente proporcional ao grau de melhora obtido com o tratamento ortodôntico ${ }^{85}$.

Este índice avalia as seguintes características oclusais: a oclusão posterior; o relacionamento dos incisivos no sentido ântero-posterior (trespasse horizontal); o relacionamento vertical entre os incisivos (trespasse vertical); a linha média e o apinhamento.

Na avaliação da oclusão posterior, o índice PAR não avalia a relação molar, mas a intercuspidação dos segmentos posteriores do arco, desta forma a relação molar de Classe II não é considerada como uma característica predictiva de má oclusão ${ }^{16}$. Assim, no tratamento da Classe II, com extrações de dois pré-molares superiores, onde os molares são finalizados em relação de Classe II não há uma penalização no cálculo do índice PAR como observado no IPT ${ }^{7}$. 
Segundo RICHMOND ${ }^{84}$, em 1993, pode-se considerar que o tratamento ortodôntico apresentou uma boa qualidade quando a redução média do índice PAR for maior que $70 \%$.

Com o intuito de verificarem a confiabilidade do índice PAR nos Estados Unidos, DeGUZMAN et al. ${ }^{31}$, em 1995, solicitaram que um grupo de onze ortodontistas norte-americanos avaliassem 200 modelos de gesso quanto à severidade da má oclusão e o nível de complexidade do tratamento. A partir dos resultados obtidos, os autores atribuíram pesos diferentes a cada um dos componentes do índice. As maiores diferenças entre os modelos britânico e norte-americano relacionam-se ao trespasse horizontal a à avaliação do segmento ântero-inferior que foi eliminado pelo sistema dos Estados Unidos. Os autores concluíram que o índice PAR constitui-se em um método eficiente na avaliação da eficácia do tratamento ortodôntico.

\subsection{Considerações gerais sobre este capítulo}

A revisão de literatura demonstrou que a Classe II dentária, sem comprometimento esquelético significativo, potencial de crescimento craniofacial reduzido e sem uma quantidade significativa de apinhamento e/ou protrusão no arco inferior, pode ser tratada por meio das extrações de dois pré-molares superiores ou pela utilização de aparelhos 
distalizadores $^{40-43,47,62}$. Muitos estudos M $^{19,20,25,35,37,60}$ demonstraram a eficácia do aparelho Pendulum durante a distalização, contudo poucos trabalhos ${ }^{5,17,105}$ realizaram avaliações após a finalização com o aparelho fixo. Recentemente, várias investigações ${ }^{7,14,44,51,53,70,71}$ foram realizadas a fim de comparar as extrações de dois pré-molares a outros protocolos de tratamento, demonstrando que a manutenção da relação molar de Classe II no tratamento com as extrações de dois pré-molares facilita a sua correção, possibilitando a obtenção dos melhores resultados oclusais $^{7,14,51}$, num menor período de tempo ${ }^{7,70,71}$. Baseando-se nestas observações, torna-se oportuna a comparação entre os graus de eficiência destes dois protocolos de tratamento. 
3 Proposição 


\section{PROPOSIÇÃO}

O objetivo deste estudo é testar, considerando-se os resultados oclusais e o tempo de tratamento, a seguinte hipótese nula: não há diferença entre os graus de eficiência do tratamento da má oclusão de Classe II realizado com o aparelho Pendulum e com extrações de dois pré-molares superiores. 
4 Material e Métodos 


\section{MATERIAL E MÉTODOS}

\subsection{Material}

A seleção da amostra foi de caráter retrospectivo, realizada a partir dos prontuários pertencentes ao arquivo da disciplina de Ortodontia da Faculdade de Odontologia de Bauru - Universidade de São Paulo, de acordo com os seguintes critérios:

- má oclusão de Classe II, tratada com o aparelho Pendulum ou com extrações de dois pré-molares superiores;

- presença de todos os dentes permanentes até os primeiros molares irrompidos;

- ausência de supranumerários;

- ausência de dentes impactados;

- ausência de anomalias relacionadas ao tamanho e/ou a forma dos dentes;

- tratamento finalizado com aparelho fixo, com acessórios padrão ou pré-ajustado (prescrição de Roth), pela mecânica Edgewise e

- prontuário ortodôntico completo.

A amostra compôs-se dos modelos e telerradiografias de 48 pacientes, divididos em dois grupos experimentais de acordo com o 
protocolo de tratamento utilizado para a correção da má oclusão de Classe II:

- Grupo 1: constituído por 22 pacientes tratados com o aparelho Pendulum, com idade inicial média de 14,44 \pm 1,85 anos (idade mínima de 11,60 e máxima de 17,65), sendo 7 do gênero masculino e 15 do feminino. Em relação à severidade da discrepância ântero-posterior, 6 pacientes eram portadores de Classe II completa, 6 de 3/4 de Classe II, 6 de 1/2 Classe II e 4 de 1/4 de Classe II. Considerando-se o tipo de má oclusão, 19 pacientes apresentavam Classe II $1^{\underline{\underline{a}}}$ divisão e 3 , Classe II $2^{\underline{a}}$ divisão. Estes pacientes fizeram parte de uma amostra prospectiva, tratada por apenas dois alunos do curso de pósgraduação da Faculdade de Odontologia de Bauru Universidade de São Paulo. A relação molar de Classe II foi corrigida por meio do uso do aparelho Pendulum, para distalização dos molares superiores, seguido da instalação do aparelho ortodôntico fixo. Neste grupo, os pacientes utilizaram o botão de Nance e o aparelho extrabucal como reforços de ancoragem.

- Grupo 2: composto por 26 pacientes, todos com má oclusão de Classe II completa, tratados com extrações de dois pré-molares superiores, com idade inicial média de 13,66 \pm 0,91 anos (idade mínima de 12 e máxima de 15,08), sendo 14 do gênero 
masculino e 12 do feminino. Em relação ao tipo de má oclusão, a distribuição foi de 22 portadores de má oclusão de Classe II $1^{\underline{a}}$ divisão e 4 de Classe $\| 2^{\underline{a}}$ divisão. Os pacientes foram tratados por alunos dos cursos de pós-graduação da referida instituição, sob supervisão dos professores orientadores. Todos foram planejados, desde o início do tratamento, com as extrações de dois pré-molares superiores. Neste grupo os pacientes utilizaram o aparelho extrabucal como reforço de ancoragem e o aparelho fixo.

\subsection{Métodos}

\subsubsection{Prontuários ortodônticos}

Os prontuários ortodônticos, pertencentes ao arquivo da disciplina de Ortodontia da Faculdade de Odontologia de Bauru - Universidade de São Paulo, da amostra selecionada foram avaliados para a obtenção de dados relevantes à realização deste estudo.

O nome completo do paciente, o gênero e a data de nascimento foram obtidos a partir das fichas de dados cadastrais. Os protocolos de tratamento propostos foram avaliados nas fichas de planejamento terapêutico inicial. Nas fichas de procedimentos terapêuticos diários 
consultamos a data do início (instalação das bandas ou do aparelho Pendulum) e do final do tratamento (remoção do aparelho fixo), que conjuntamente à data de nascimento, permitiu o cálculo preciso da idade inicial do paciente e do tempo total de tratamento. Na ficha do relatório final avaliamos se o planejamento inicial foi cumprido.

\subsubsection{Tratamento ortodôntico}

\section{Grupo 1:}

Este grupo pertence a uma amostra prospectiva tratada por apenas dois operadores, alunos do curso de pós-graduação, stricto sensu, da referida instituição. Inicialmente utilizou-se o aparelho Pendulum (figura 1) para a distalização dos molares superiores e correção da relação molar de Classe II, com a liberação de uma força distalizadora de 253,3g por lado, durante um período médio de $5,85 \pm 1,82$ meses. 0 aparelho Pendulum foi removido após a obtenção de uma relação molar normal, com a sobrecorreção aproximada de $2 \mathrm{~mm}$. Em seguida, um botão palatino de Nance foi instalado, com a finalidade de conter a tendência à recidiva dos molares distalizados. Este aparelho foi construído adaptandose o fio que emerge do botão acrílico palatino ao tubo lingual dos primeiros molares superiores, anteriormente utilizado para inserção das molas distalizadoras do aparelho Pendulum. Este sistema foi estabilizado 
com um fio de amarrilho, de maneira a prender firmemente o botão de Nance às bandas dos primeiros molares superiores. Este aparelho foi instalado no mesmo dia da remoção do Pendulum, sendo que, no período decorrido da remoção do aparelho distalizador até a confecção laboratorial do botão palatino de Nance, utilizou-se como contenção um botão de resina acrílica confeccionado individualmente na própria cavidade bucal do paciente. Além disso, adaptou-se um aparelho extrabucal de tração cervical, com intensidade de força de 400 a $500 \mathrm{~g} / \mathrm{lado}$, somente para uso noturno, de maneira a cooperar na manutenção do espaço obtido na distalização e proporcionar a verticalização das raízes dos primeiros molares distalizados.

Após trinta dias, seguiu-se a montagem do aparelho ortodôntico fixo com acessórios da marca ABZIL, prescrição Roth e ranhura 0.022 x 0.028", iniciando-se a seqüência convencional de fios níquel-titânio e de aço redondos para o alinhamento e nivelamento dentários até o fio retangular 0.019 x 0.025", quando foi realizada a retração dos pré-molares superiores um a um (quando esta não ocorreu espontaneamente devido à ação das fibras transeptais). Para a realização da retração ântero-superior (caninos e incisivos superiores), removeu-se o botão palatino de Nance e além do reforço de ancoragem representado pelo aparelho extrabucal de uso noturno, utilizou-se os elásticos de Classe II, de 1/4 polegada, para 0 uso de 12 à 20h/dia. Fechados os espaços, procedeu-se com a finalização e a intercuspidação dos casos. Após a remoção do aparelho 
ortodôntico fixo, instalou-se a placa de Hawley superior e o $3 \times 3$ inferior para a contenção. O tempo médio de tratamento foi de 3,81 anos.
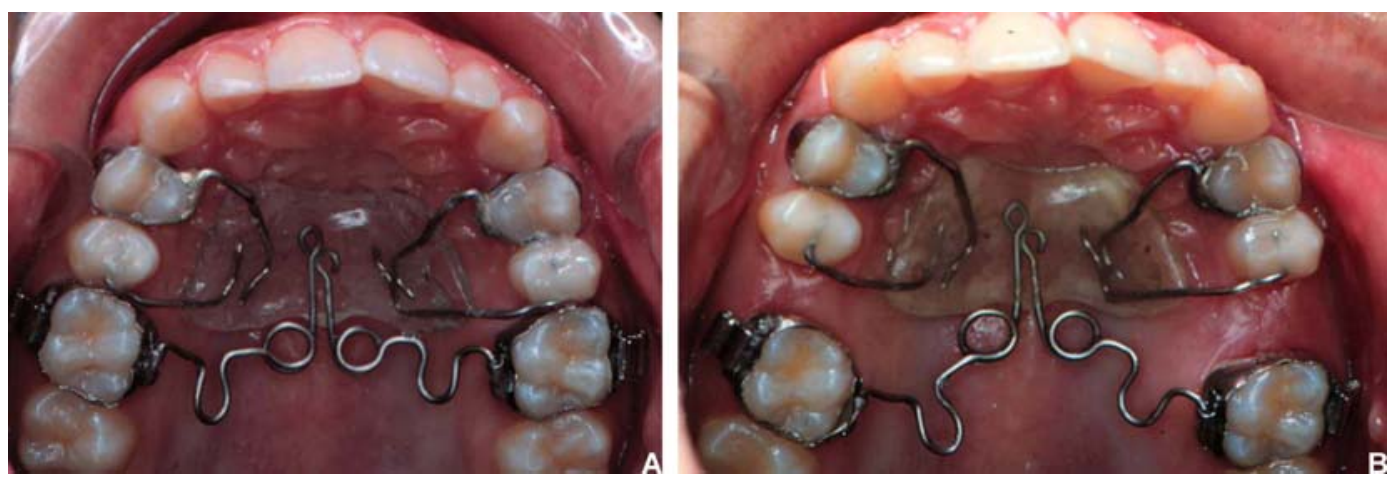

FIGURA 1 - Aparelho Pendulum (A - início do tratamento; B - pósdistalização).

\section{Grupo 2:}

O grupo 2 consistiu de 26 pacientes tratados por alunos do curso de pós-Graduação, lato e stricto sensu, em Ortodontia da Faculdade de Odontologia de Bauru - Universidade de São Paulo. Desde o planejamento inicial dos casos, optou-se pelas extrações de dois prémolares superiores (figura 2).

O tratamento foi realizado com aparelho fixo pela mecânica Edgewise em braquetes com ranhuras de $0.022 \times 0.028$ ". O aparelho extrabucal foi utilizado como reforço de ancoragem. O tratamento ortodôntico fixo transcorreu de forma convencional, sendo: alinhamento e nivelamento dentários (iniciando-se a seqüência com fios níquel - titânio 
seguidos por fios de aço inoxidável redondos até ao fio retangular $0.019 \mathrm{x}$ 0.025"), retração anterior superior, finalização e intercuspidação. Após a remoção do aparelho ortodôntico fixo, instalou-se a placa de Hawley superior e o $3 \times 3$ inferior para a contenção. 0 tempo médio de tratamento foi de 1,92 anos. Os casos foram finalizados com relação molar de Classe II, o que é considerado normal para este protocolo de tratamento ${ }^{7,15,30,44,58,77,94}$ e relação normal de caninos.

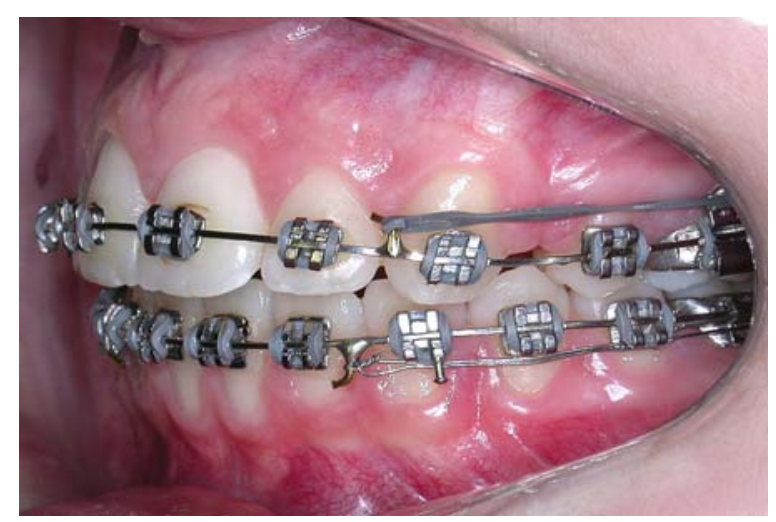

FIGURA 2 - Tratamento com extrações de dois pré-molares superiores. 


\subsubsection{Traçados e medições das radiografias}

As telerradiografias iniciais em norma lateral foram utilizadas para a verificação da compatibilidade entre os grupos. Para isto, uma folha de papel "ultraphan" de $0,07 \mathrm{~mm}$ de espessura, de $17,5 \times 17,5 \mathrm{~cm}$ foi adaptada em cada telerradiografia. O traçado anatômico e a demarcação dos pontos de referência dentoesqueléticos e tegumentares foram efetuados manualmente, com lapiseira de 0,5mm, sobre um negatoscópio, em sala escurecida. Após a realização dos traçados anatômicos, os mesmos foram conferidos por outro examinador, para garantir uma ampla margem de segurança quanto à exatidão dos traçados. Em seguida, o traçado anatômico e os pontos demarcados foram digitalizados em uma mesa digitalizadora Numonics AccuGrid XNT, modelo A30TL.F ${ }^{1}$, acoplada a um microcomputador Pentium III 166Mhz.

O programa utilizado para a medição das grandezas cefalométricas foi o Dentofacial Planner $7.02^{2}$, efetuando-se por meio do mesmo a correção da magnificação da imagem radiográfica, variando entre 6 e 9,8\% em função dos diferentes aparelhos radiográficos utilizados.

\footnotetext{
${ }^{1}$ Numonics Corporatio - Montgomerryville - PA

${ }^{2}$ Dentofacial Planner Software Inc., Toronto,Ontario, Canada.
} 


\subsubsection{Traçado anatômico (figura 3)}

Foram delimitadas as seguintes estruturas:

- perfil mole;

- perfil do osso frontal e dos ossos nasais;

- sela túrcica;

- meato acústico externo;

- fissura pterigomaxilar;

- limite póstero-inferior da cavidade orbitária;

- maxila;

- mandíbula;

- incisivos centrais superiores e inferiores;

- pré-molares superiores e inferiores;

- primeiros molares superiores e inferiores.

Para todas as estruturas bilaterais, traçou-se a média. 


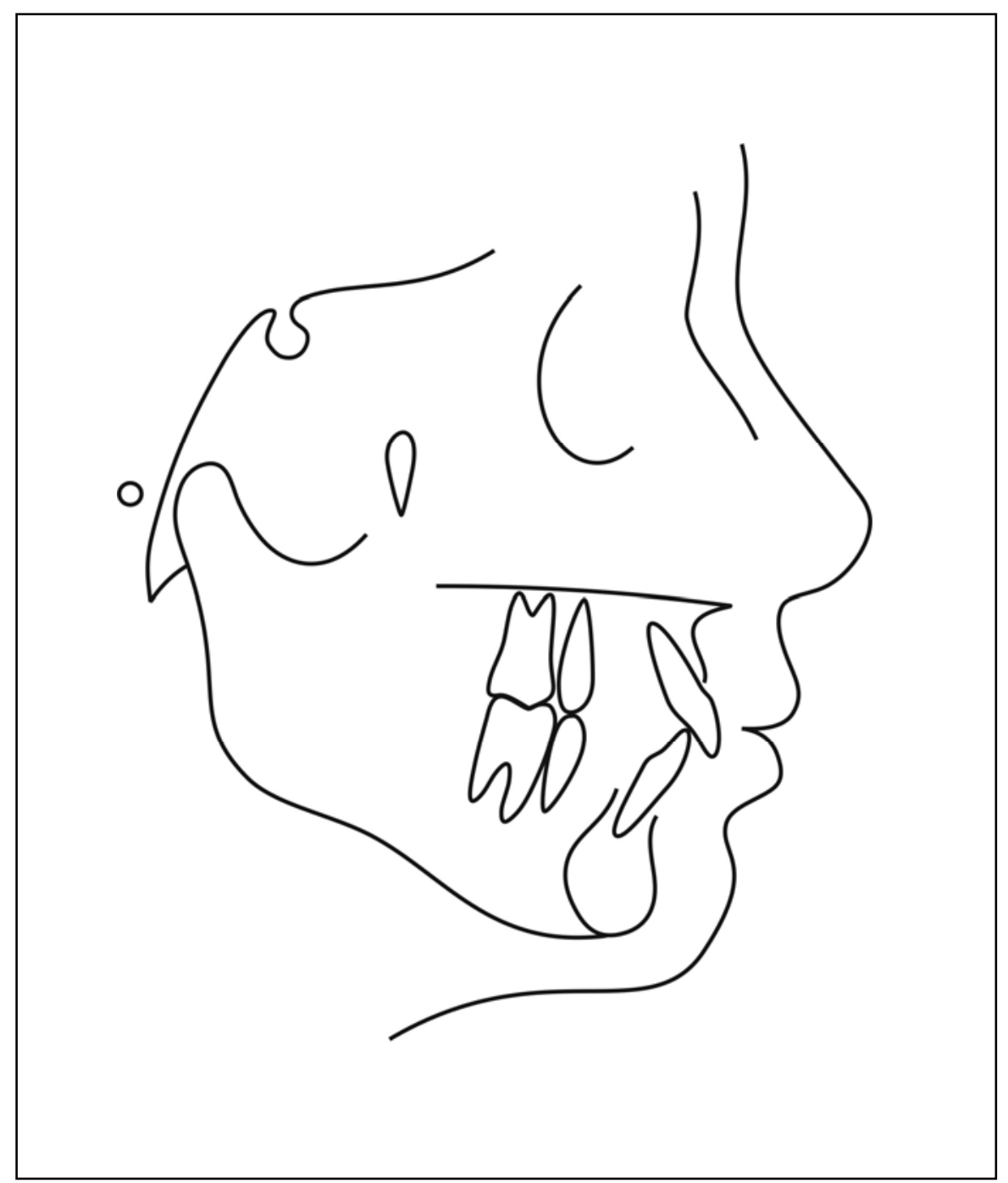

FIGURA 3 - Desenho anatômico. 


\subsubsection{Pontos de referência, linhas e planos}

\section{Pontos de referência (figura 4)}

Os pontos de referência anatômicos foram demarcados seguindo as especificações de KROGMAN; SASSOUNI ${ }^{64}$, RIOLO et al. ${ }^{88}$, MCNAMARA JR ${ }^{75}$, JACOBSON $^{50}$, LEGAN, BURSTONE $^{65}$, STEINER $^{104}$ e RICKETTS ${ }^{87}$.

1. S (sela túrcica): ponto central da sela túrcica;

2. N (násio): ponto anterior da sutura frontonasal;

3. Or (orbitário): a média dos pontos inferiores das margens inferiores das órbitas;

4. ENA (espinha nasal anterior): ponto anterior da espinha nasal anterior;

5. ENP (espinha nasal posterior): ponto posterior do assoalho da fossa nasal;

6. Ponto A (subespinhal): ponto profundo da concavidade anterior da maxila, entre a espinha nasal anterior e o próstio;

7. Ponto B (supramentoniano): o ponto profundo da concavidade da sínfise mentoniana;

8. Pog (pogônio): o ponto anterior do contorno do mento ósseo; 
9. Gn (gnatio): o ponto inferior e anterior do contorno do mento ósseo, determinado pela bissetriz entre as linhas NPog e o plano mandibular (GoMe);

10. Me (mentoniano): o ponto inferior da sínfise mentoniana;

11. Go (gônio): o ponto determinado pela intersecção da bissetriz do ângulo formado entre as tangentes às bordas posterior e inferior da mandíbula;

12. Po (pório anatômico): o ponto superior do meato acústico externo;

13. Co (condílio): o ponto posterior e superior do côndilo mandibular;

14. BIS (borda incisal superior): o ponto inferior da borda incisal do incisivo central superior;

15. AIS (ápice incisal superior): o ponto superior do ápice radicular do incisivo central superior;

16. BII (borda incisal inferior): o ponto superior da borda incisal do incisivo central inferior;

17. All (ápice incisal inferior): o ponto inferior do ápice radicular do incisivo central inferior;

18. SMPMS (superfície mesial do primeiro molar superior); o ponto anterior da coroa do primeiro molar permanente superior;

19. CMPMS (cúspide mesial do primeiro molar superior): o ponto inferior da cúspide mesial do primeiro molar permanente superior; 
20. SMPMI (superfície mesial do primeiro molar inferior): o ponto anterior da coroa do primeiro molar permanente inferior;

21. CMPMI (cúspide mesial do primeiro molar inferior): o ponto superior da cúspide mesial do primeiro molar permanente inferior;

22. COM (contato oclusal molar): o ponto médio da superfície de intercuspidação dos primeiros molares;

23. COPM (contato oclusal pré-molar): ponto médio da superfície de intercuspidação dos segundos pré-molares;

24. Ls (Lábio superior): ponto na região anterior do lábio superior;

25. Li (Lábio inferior): ponto localizado na região anterior do lábio inferior;

26. Pog' (Pogônio mole): ponto anterior no contorno do mento mole;

27. $\operatorname{Pr}$ (Pronasal): ponto anterior do nariz;

28. Cn (Columela nasal): ponto inferior da borda inferior do nariz;

29. Sn (Subnasal): ponto em que a columela intersecta-se com o lábio superior no plano médio sagital;

30. Gl (glabela): o ponto anterior da testa, na região das bordas superiores das órbitas.

Além desses pontos, estritamente relacionados com estruturas anatômicas, foram construídos dois pontos para efeitos de digitalização: 
31.ENAperp (ponto espinha nasal anterior perpendicular): ponto localizado arbitrariamente ao nível dos incisivos superiores, porém perpendicular ao plano palatino, a partir do ponto ENA;

32.Pogperp (ponto pogônio perpendicular): ponto localizado arbitrariamente ao nível dos incisivos inferiores, porém perpendicular ao plano Go-Me, a partir do ponto Pog. 


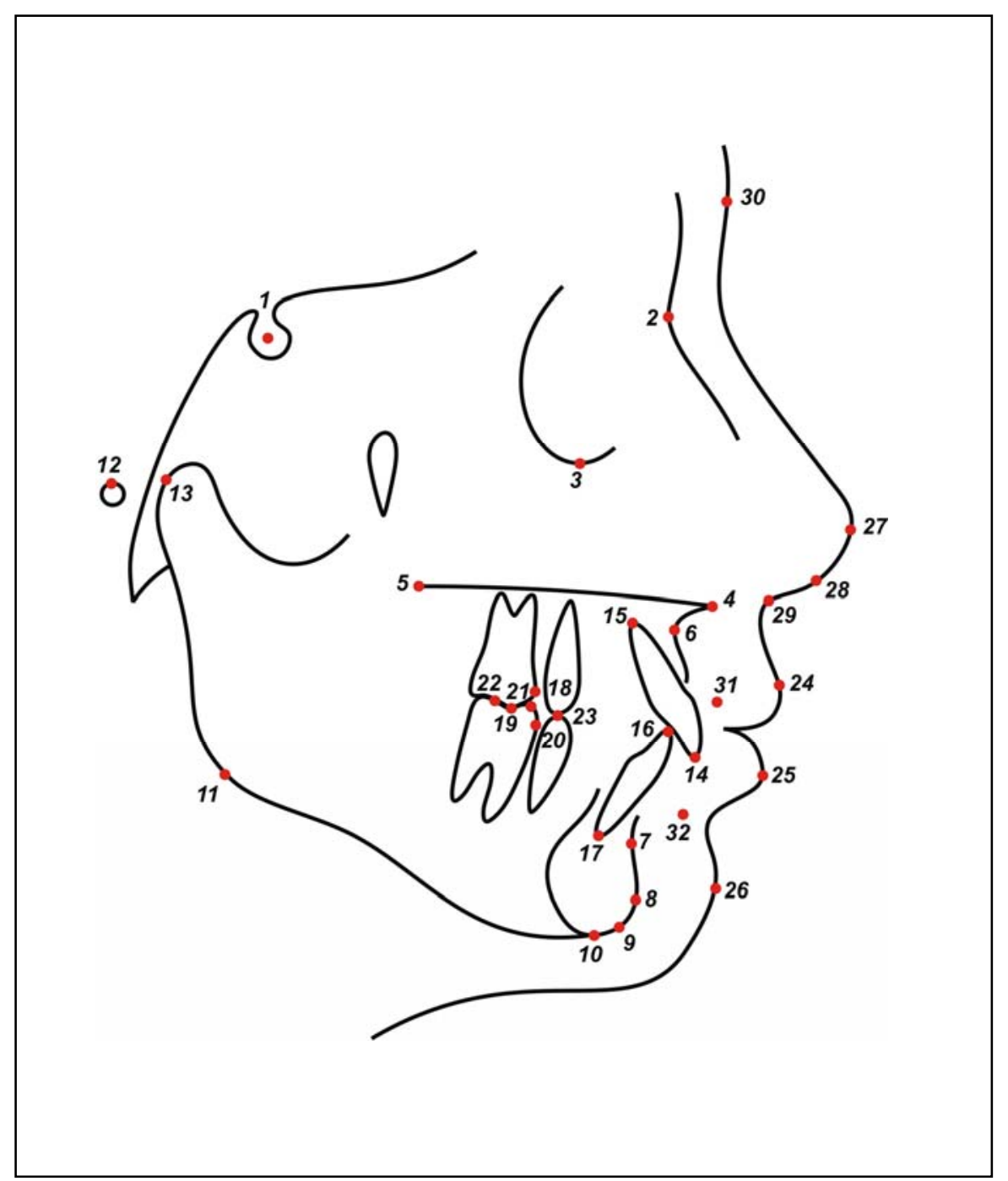

FIGURA 4 - Pontos de referência.

1) $\mathrm{S}$; 2) $\mathrm{N}$; 3) Or; 4) ENA; 5) ENP; 6) $\mathrm{A}$; 7) $\mathrm{B}$; 8) Pog; 9) $\mathrm{Gn}$; 10) Me; 11) $\mathrm{Go}$; 12) $\mathrm{Po}$; 13) $\mathrm{Co}$; 14) BIS; 15) AIS; 16) Bll; 17) All; 18) SMPMS; 19) CMPMS; 20) SMPMI; 21) CMPMI; 22) COM; 23) COPM; 24) Ls; 25) Li; 26) Pog'; 27) Pr; 28) Cn; 29) Sn; 30) Gl; 31) ENAperp; 32) Pogperp 


\section{Linhas e planos (figura 5)}

\section{Horizontais}

A. Linha SN: do ponto sela ao násio;

B. FH (plano horizontal de Francfort): do ponto pório ao orbitário;

C. PP (plano palaltino): do ponto ENA ao ENP;

D. POF (plano oclusal funcional): do contato oclusal pré-molar ao contato oclusal molar;

E. GoGn (plano mandibular): do ponto gônio ao gnátio;

F. GoMe (plano mandibular): do ponto gônio ao mentoniano;

G. Linha que passa pela columela nasal $(\mathrm{Cn})$ até o ponto $\mathrm{Sn}$;

H. Linha que se estende do ponto Sn até o ponto Ls;

\section{Verticais}

I. Linha NA: une o ponto násio ao ponto A;

J. Linha NB: une o ponto násio ao ponto B;

K. Linha BIS-AIS (longo eixo do incisivo superior): une os pontos correspondentes da borda incisal ao ápice dos incisivos centrais superiores;

L. Linha Bll-All (longo eixo do incisivo inferior): une os pontos correspondentes da borda incisal ao ápice dos incisivos centrais inferiores; 
M. Linha Nperp: linha perpendicular ao plano de Francfort, passando pelo ponto násio;

N. Linha Pogperp: linha perpendicular ao plano mandibular GoMe, passando pelo ponto pogônio;

O. Linha ENAperp: linha perpendicular ao plano palatino, passando pela espinha nasal anterior:

P. Plano CoGo: do ponto condílio ao ponto gônio;

Q. Linha E: linha que une os pontos Pr e Pog';

R. Linha que une os pontos ENA e Me;

S. Linha APog: formada entre os pontos A e Pog. 


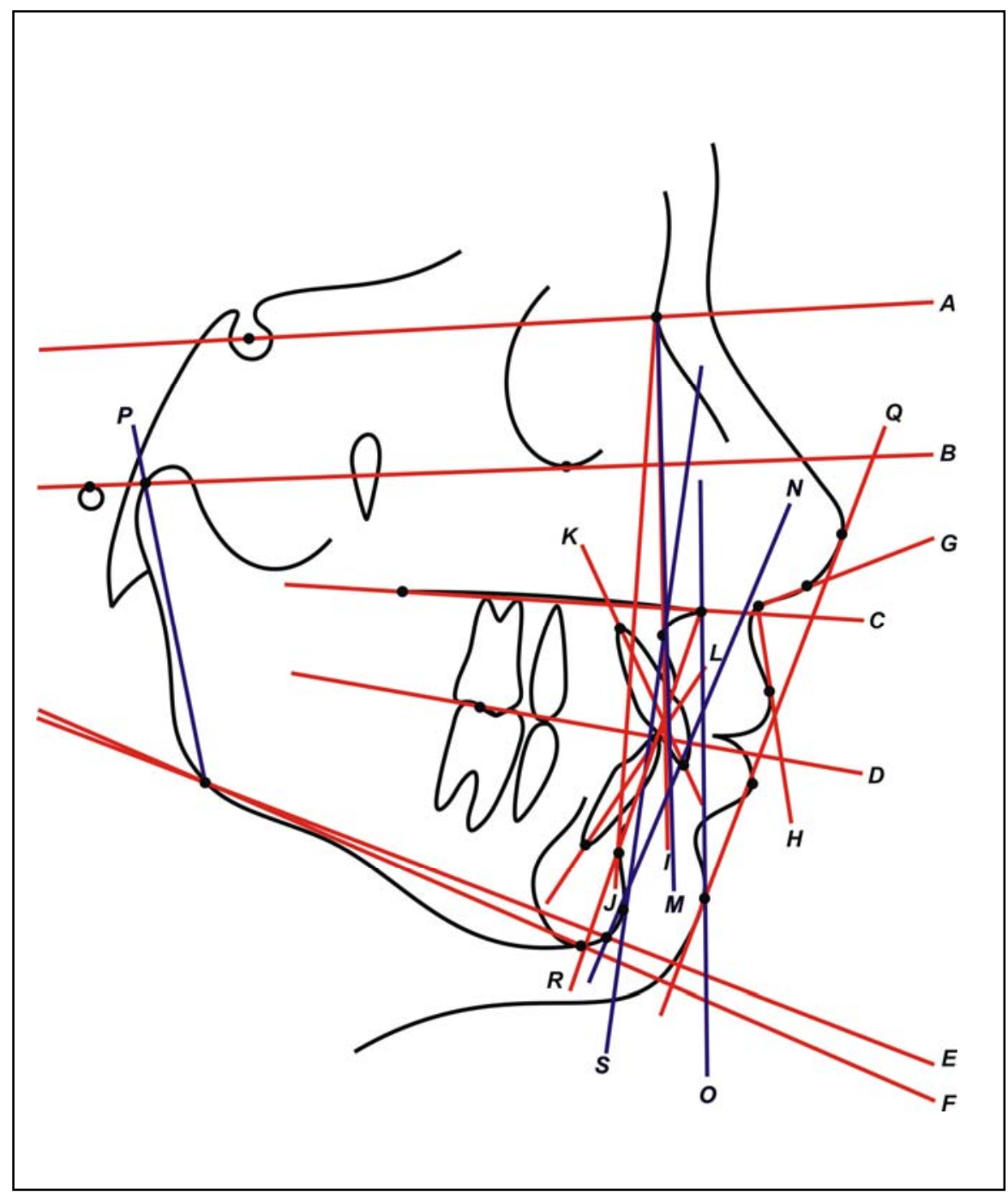

FIGURA 5 - Linhas e planos.

A) $\mathrm{SN}$; B) $\mathrm{FH}$; C) PP; D) POF; E) GoGn; F) GoMe; G) Cn-Sn; H) Sn-

Ls; I) NA; J) NB; K) BIS-AIS; L) BII-AII; M) Nperp; N) Pogperp; O)ENAperp; P) CoGo; Q) E; R) ENA-Me; S) APog 


\subsubsection{Grandezas cefalométricas esqueléticas (figura 6)}

\section{Componentes maxilares}

1- SNA $\left({ }^{\circ}\right)$ : ângulo formado pelas linhas SN e NA. Indica a relação sagital da maxila em relação à base do crânio;

2- Co-A (mm): distância entre os pontos condílio e A. Representa o comprimento efetivo da maxila;

3- A-Nperp (mm): distância entre o ponto $A$ e a linha násio perpendicular. Define a posição sagital da maxila.

\section{Componentes mandibulares}

4. SNB $\left({ }^{\circ}\right)$ : ângulo formado pelas linhas SN e NB. Indica a relação sagital da mandíbula, em relação à base do crânio;

5. Co-Gn (mm): distância entre os pontos condílio e gnátio. Define o comprimento efetivo mandibular;

6. Go-Gn (mm): distância entre os pontos gônio e gnátio. Avalia o comprimento do corpo mandibular;

7. Co-Go (mm): distância entre os pontos condílio e gônio. Representa a altura do ramo mandibular;

8. Pog-Nperp (mm): distância entre o ponto Pog e a linha násio perpendicular. Define a posição sagital da mandíbula. 


\section{Relação entre maxila e mandíbula}

9. ANB $\left({ }^{\circ}\right)$ : ângulo entre as linhas NA e NB. Representa o grau de discrepância sagital entre a maxila e mandíbula;

10. Wits $(\mathrm{mm})$ : distância entre as projeções perpendiculares dos pontos A e B sobre o plano oclusal funcional (POF). Define o relacionamento sagital entre a maxila e mandíbula;

11. Co-A/Co-Gn (mm): proporção entre os comprimentos maxilar e mandibular. Avalia o crescimento diferencial da mandíbula em relação à maxila;

12. NAPog $\left({ }^{0}\right)$ : ângulo entre as linhas NA e APog. Descreve o grau de convexidade do perfil ósseo;

\section{Padrão de Crescimento}

13. FMA $\left({ }^{\circ}\right)$ : ângulo formado pelos planos horizontal de Francfort e mandibular (GoMe). Define basicamente a orientação do padrão de crescimento facial;

14. SN.GoGn( $\left(^{\circ}\right)$ : ângulo formado pela linha $S N$ e o plano mandibular GoGn. Utilizando-se de pontos cefalométricos diferentes, também define a orientação do padrão de crescimento facial; 
15. SN.PP $\left({ }^{\circ}\right)$ : ângulo formado pela linha $S N$ e o plano palatino. Indica o posicionamento da porção basal maxilar;

16. AFAl (mm): distância entre os pontos espinha nasal anterior e mentoniano. Indica a altura do terço inferior da face. 


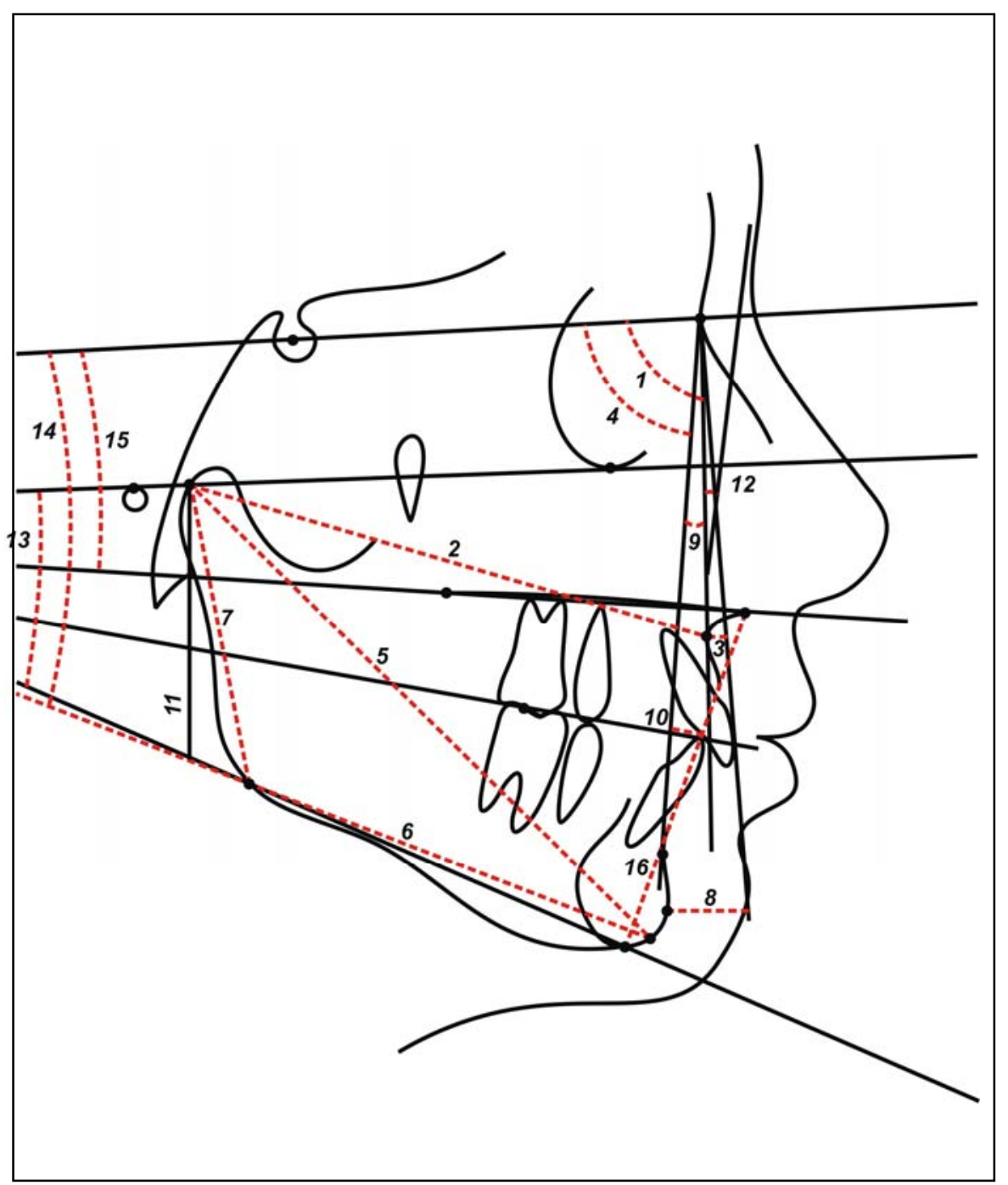

FIGURA 6 - Grandezas cefalométricas esqueléticas.

1) SNA; 2) Co-A; 3) A-Nperp; 4) SNB; 5) Co-Gn; 6) Go-Gn; 7) Co-Go;

8) Pog-Nperp; 9) ANB; 10) Wits; 11) Co-A/Co-Gn; 12) NAPog; 13) FMA; 14)SN.GoGn; 15) SN.PP; 16) AFAI 


\subsubsection{Grandezas cefalométricas dentárias (figura 7)}

\section{Componente dentoalveolar superior}

1- 1.PP $\left(^{\circ}\right)$ : ângulo entre o longo eixo do incisivo central superior e o plano palatino. Relaciona a inclinação do incisivo superior à maxila;

2- 1.NA $\left(^{\circ}\right)$ : ângulo entre o longo eixo do incisivo central superior e a linha NA. Define o grau de inclinação do incisivo central em relação à maxila e ao násio;

3- 1-NA (mm): distância entre o ponto mais anterior da coroa do incisivo central superior e a linha NA. Relaciona a posição sagital do incisivo superior em relação à maxila e ao násio;

4- 1-ENAperp (mm): distância entre o ponto mais anterior da coroa do incisivo central superior e a linha espinha nasal anterior perpendicular. Determina a posição ântero-posterior do incisivo superior em relação à maxila;

5- 1-PP (mm): distância entre a borda incisal do incisivo central superior e o plano palatino. Determina a altura do processo alveolar superior em sua região anterior;

6- 6-PP (mm): distância entre a cúspide mesiovestibular do primeiro molar superior e o plano palatino. Avalia a altura do processo alveolar em sua região posterior; 
7- 6-ENAperp (mm): distância entre a face mesial do primeiro molar superior e a linha espinha nasal anterior perpendicular. Determina a posição ântero-posterior do primeiro molar superior, em relação à maxila;

\section{Componente dentoalveolar inferior}

8- IMPA $\left({ }^{\circ}\right)$ : ângulo entre o longo eixo do incisivo central inferior e o plano mandibular (GoMe). Indica a inclinação desse dente em relação à mandíbula;

9- 1.NB( $\left(^{\circ}\right.$ : ângulo entre o longo eixo do incisivo inferior e a linha NB. Relaciona a inclinação desse dente com a mandíbula e o násio;

10-1-NB (mm): distância entre o ponto mais anterior da coroa do incisivo central inferior e a linha NB. Relaciona a posição sagital do incisivo inferior em relação à mandíbula e ao násio;

11-1-Pogperp (mm): distância entre o ponto mais anterior da coroa do incisivo central inferior e a linha pogônio perpendicular. Determina a posição ântero-posterior do incisivo central inferior, em relação à mandíbula;

12- 1-GoMe (mm): distância entre a borda incisal do incisivo central inferior e o plano mandibular. Determina a altura do processo alveolar inferior em sua região anterior; 
13-6-GoMe (mm): distância entre a cúspide mesiovestibular do primeiro molar inferior e o plano mandibular. Determina a altura do processo alveolar inferior em sua região posterior;

14-6-Pogperp (mm): distância entre a face mesial do primeiro molar inferior e a linha pogônio perpendicular. Determina a posição ântero-posterior do primeiro molar inferior em relação à mandíbula. 


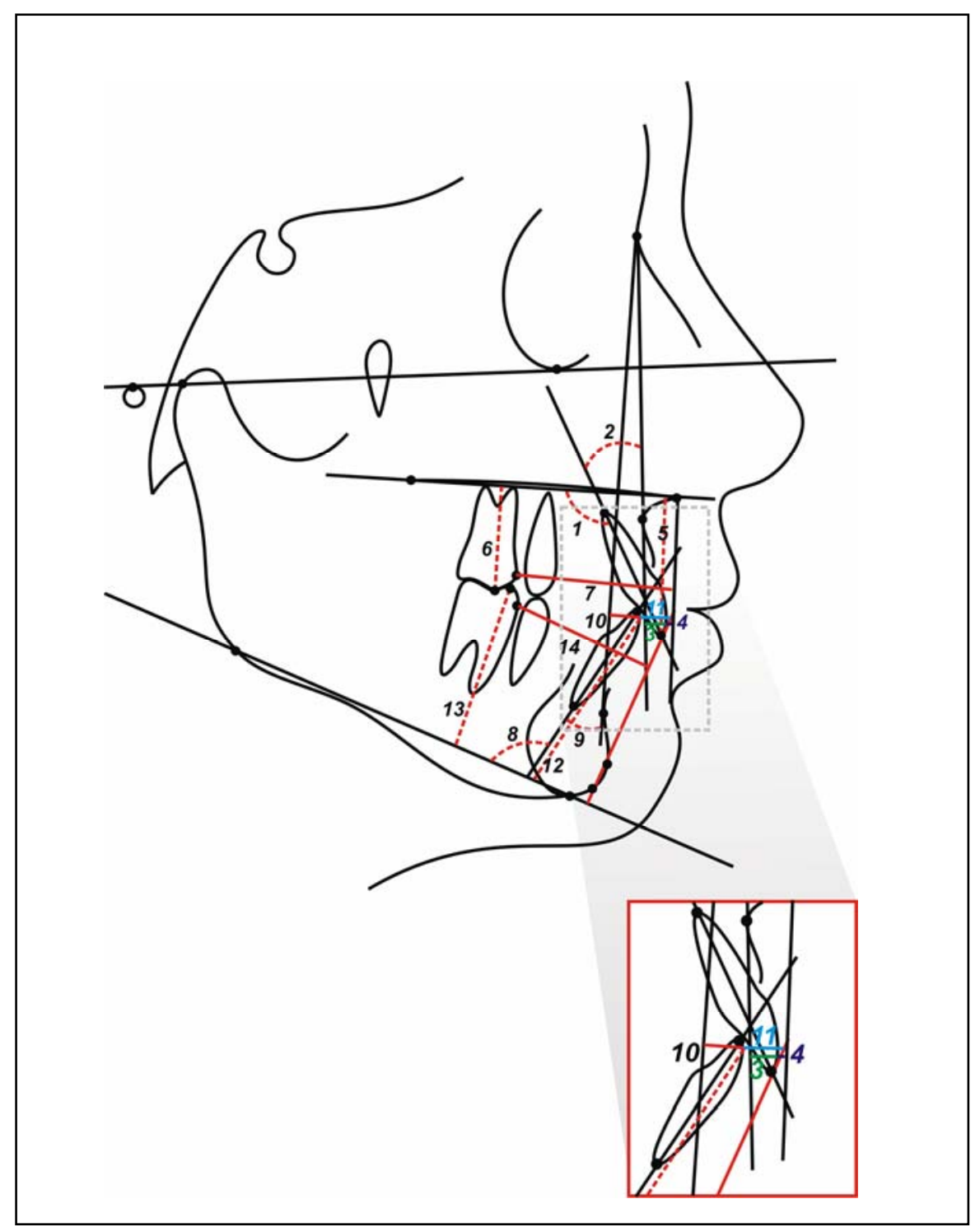

FIGURA 7 - Grandezas cefalométricas dentárias.

1) 1.PP; 2) 1.NA; 3) 1-NA; 4) 1-ENAperp; 5) 1-PP; 6) 6-PP; 7) 6ENAperp; 8) IMPA; 9) 1.NB; 10) 1-NB; 11) 1-Pogperp; 12) 1-GoMe; 13)6-GoMe; 14) 6-Pogperp 


\subsubsection{Relações dentárias (figura 8)}

1- Trespasse horizontal - TH (mm): distância da borda incisal do incisivo inferior à borda incisal do incisivo superior, medida paralelamente ao plano de Francfort;

2- Trespasse horizontal oclusal - THO (mm): distância da borda incisal do incisivo inferior à borda incisal do incisivo superior, medida paralelamente ao plano oclusal funcional;

3- Trespasse vertical - TV (mm): distância da borda incisal do incisivo inferior à borda incisal do incisivo superior, medida perpendicularmente ao plano de Francfort;

4- Relação molar - Rel. molar (mm): distância da superfície mesial do primeiro molar superior à superfície mesial do primeiro molar inferior, medida paralelamente ao plano de Francfort. Seu aumento indica uma maior mesialização do molar inferior em relação ao superior;

5- Relação molar oclusal - Rel. molar ocl (mm): distância da superfície mesial do primeiro molar superior à superfície mesial do primeiro molar inferior, medida paralelamente ao plano oclusal funcional. Seu aumento indica uma maior mesialização do molar inferior em relação ao superior. 


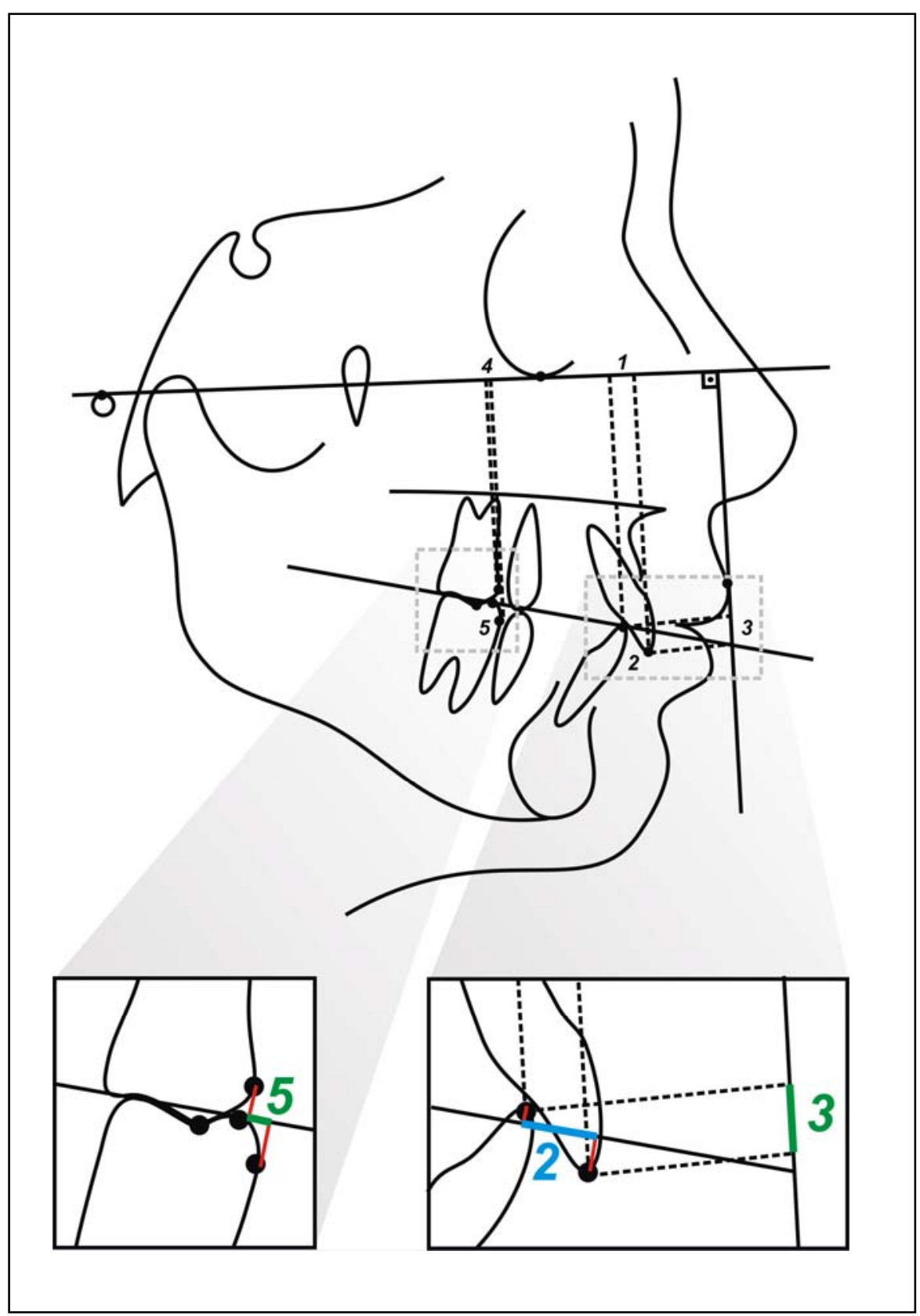

FIGURA 8 - Relações dentárias.

1) $\mathrm{TH}$; 2) $\mathrm{THO}$; 3) TV; 4) Rel. molar; 5) Rel. molar ocl 


\subsubsection{Grandezas cefalométricas tegumentares (figura 9)}

1- Convexidade tegumentar (Conv teg): ângulo formado pelas linhas pogônio'-subnasal e subnasal-glabela;

2- Ângulo nasolabial (ANL): formado pelas linhas subnasal columela e subnasal - lábio superior;

3- H-nariz (mm): distância entre o ponto mais anterior do nariz à linha $\mathrm{H}$;

4- Lábio superior à linha $E$ (Ls-E): distância entre o lábio superior à linha formada pelo pogônio (tecido mole) e pronasal;

5- Lábio inferior à linha $E$ (Li-E): distância entre o lábio inferior à linha formada pelo pogônio (tecido mole) e pronasal;

6- Lábio superior-APog (Ls-APog): distância entre o lábio superior à linha formada pelos pontos A e Pog (tecido esquelético);

7- Lábio inferior-Apo (Li-APog): distância entre o lábio inferior à linha formada pelos pontos A e Pog (tecido esquelético). 


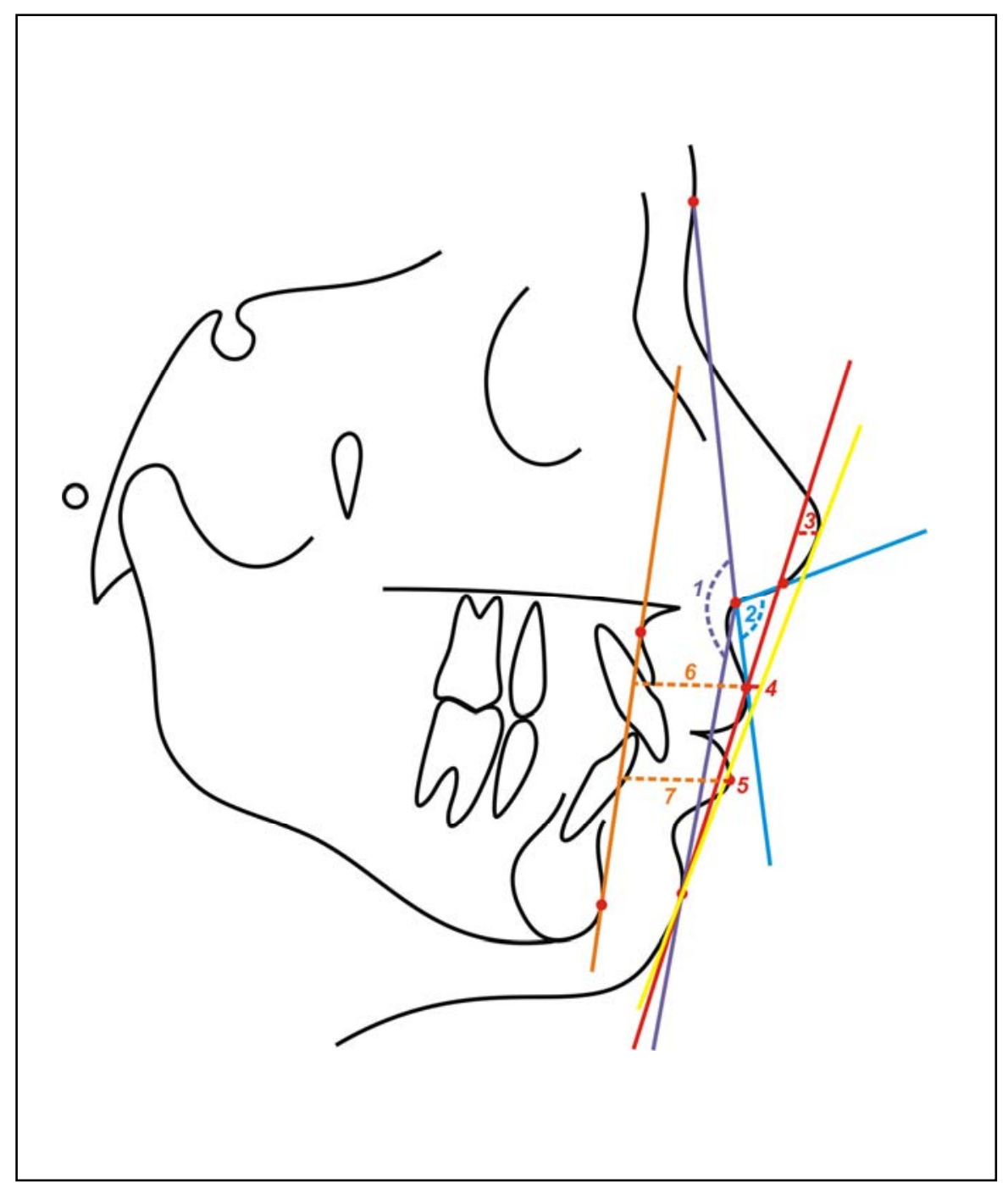

FIGURA 9- Grandezas cefalométricas tegumentares.

1) Conv teg; 2) ANL; 3) H-nariz; 4) Ls-E; 5) Li-E; 6) Ls-APog;

$$
\text { 7) Li-APog }
$$




\subsubsection{Indices oclusais IPT e PAR}

A avaliação quantitativa das relações oclusais intra e interarcos, observadas nos modelos de gesso pré e pós-tratamento, realizou-se por meio dos índices oclusais IPT e PAR.

\subsubsection{Cálculo do IPT ${ }^{45}$}

Os modelos iniciais e finais foram avaliados por meio da análise oclusal do índice de prioridade de tratamento (IPT). O IPT provê subescores em pesos para a descrição do trespasse horizontal, do trespasse vertical ou mordida aberta anterior, dos deslocamentos dentários relacionados às rotações e ao apinhamento e das mordidas cruzadas posteriores dentro da classificação das más oclusões em Classe

II, Classe III ou neutroclusão. O escore final reflete o grau de severidade da má oclusão. Com exceção da rotação e do deslocamento para vestibular ou lingual, todos os demais componentes do IPT são expressos ao longo de uma escala contínua com valores positivos e negativos. Então, casos com trespasse horizontal mandibular (Classe III) ou mordida aberta anterior são expressos como escores de trespasse horizontal e vertical negativos, respectivamente. Uma constante correspondente à oclusão molar é adicionada ao escore do IPT. O escore total da escala do 
IPT varia de 0 a 10 ou mais, com maiores escores representando más oclusões mais severas.

O IPT foi calculado a partir de uma tabela (tabela 1), onde foram avaliadas as características abaixo descritas, da seguinte forma:

1- Relação molar: constitui-se no primeiro passo para a obtenção deste índice. A classificação da relação molar define a coluna da tabela a ser utilizada e também a constante numérica a ser acrescentada ao valor final do índice.

2- Trespasse horizontal: deve-se mensurar em milímetros a quantidade de trespasse horizontal, tomando-se como referência a incisal dos incisivos superiores em relação à face vestibular dos incisivos inferiores. A partir do valor desta medida, pode-se estimar, de acordo com a tabela 1, o escore correspondente.

3- Trespasse vertical: considera-se a quantidade de terços da coroa dos incisivos inferiores que se encontram encobertos pelos incisivos superiores, obtendo-se na tabela 1 o escore correspondente.

4- Deslocamentos dentários relacionados às rotações e ao apinhamento: realiza-se a contagem do número de dentes apinhados ou girados em relação às suas posições ideais. $\mathrm{O}$ somatório final obtido desta contagem é utilizado para 
determinar na tabela o escore aplicado ao deslocamento dentário.

5- Mordida cruzada: deve-se realizar a contagem total do número de dentes posteriores cruzados por lingual ou vestibular, determinando-se o escore referente a este item.

Obtidos todos os escores, estes devem ser somados e acrescidos por uma constante de valor condizente com a relação molar inicialmente determinada.

Duas tabelas do IPT foram utilizadas para cada paciente. Em uma foram anotados os dados referentes aos modelos iniciais (IPTI) e na outra, aos modelos finais (IPTF).

$\mathrm{Na}$ análise dos modelos finais do grupo 2, tratado com extrações de dois pré-molares, considerou-se a relação molar de Classe II presente ao final do tratamento como normal ${ }^{7,15,30,44,58,77,94}$. Portanto, classificada na mesma coluna da relação molar de Classe I. 
TABELA 1 - Critérios de aplicação dos escores para os componentes do índice IPT ${ }^{45}$.

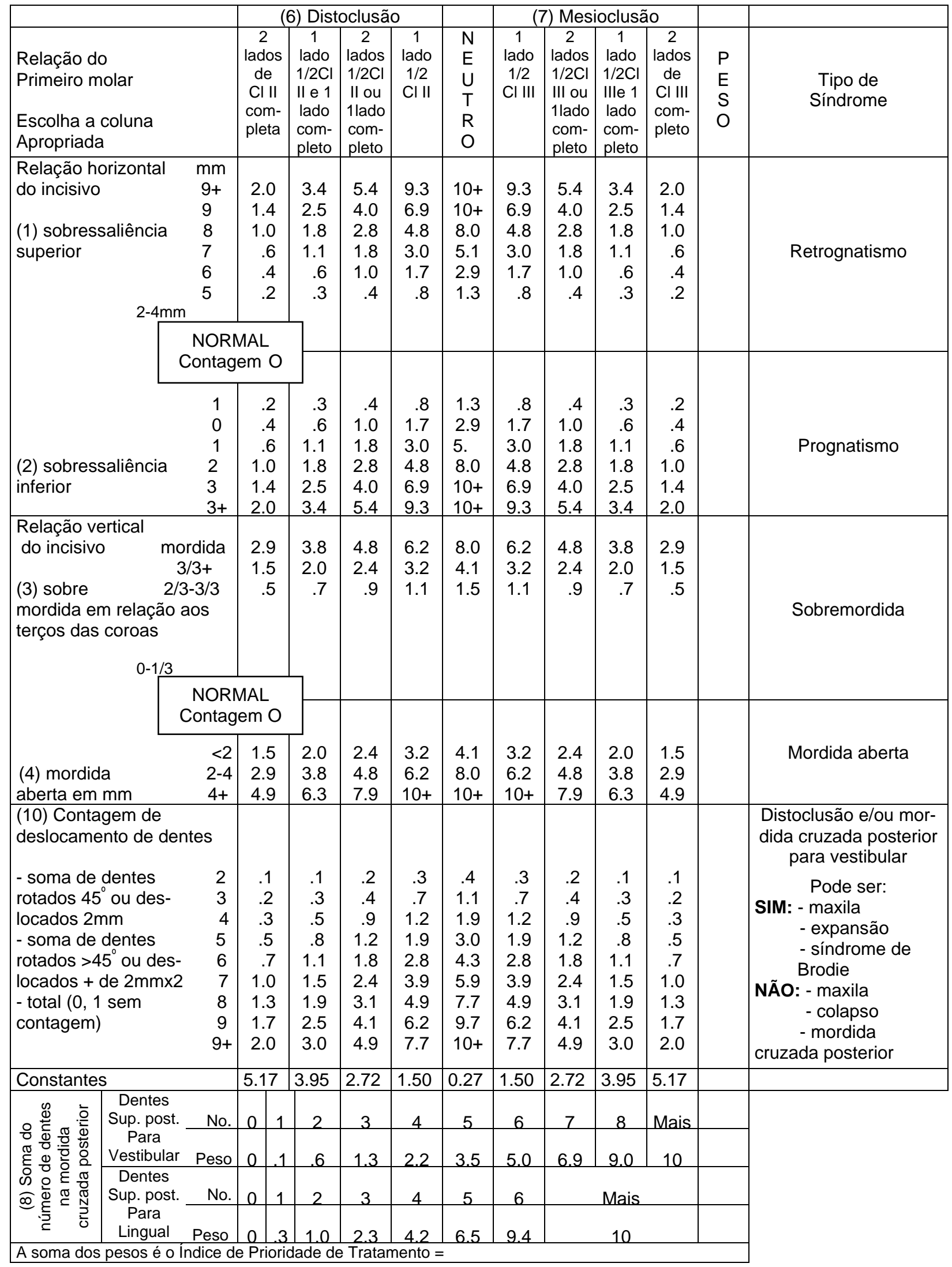




\subsubsection{Cálculo do $\mathrm{PAR}^{85}$}

O índice PAR também foi calculado nos modelos iniciais e finais de acordo com a tabela 2, na qual são avaliados:

1- Oclusão posterior: analisa-se separadamente os lados direito e esquerdo. A relação dentária posterior é avaliada nos três planos do espaço e escores são dados às discrepâncias ânteroposterior, vertical e transversa. Em seguida estes escores são somados e o valor final multiplicado por 2 .

2- Trespasse horizontal: registra-se os trespasses horizontais positivos ou negativos, tomando-se como referência a face mais proeminente de qualquer incisivo. $O$ valor medido é transformado em escore e então multiplicado por 5. Durante a medição, mantem-se a régua paralela ao plano oclusal e radial à linha do arco.

3- Trespasse vertical: verifica-se a proporção da coroa do incisivo inferior que se encontra recoberta pelo incisivo superior, tomando-se como referência o dente com maior sobreposição. Em casos de mordida aberta avalia-se em milímetros o grau de sua severidade. O escore é fornecido pela tabela e multiplicado por 3.

4- Apinhamento: registrado apenas para a região ântero-superior dos arcos dentários. Deve-se avaliar a ocorrência de apinhamento, diastema e impacção dentária, sendo que as 
medidas são tomadas tendo como referência a menor distância entre os pontos de contato dos dentes adjacentes. Estas medidas também são transformadas em escores de acordo com a tabela 2 e, então, somados. A impacção dentária é considerada quando o espaço destinado ao dente for menor do que 4 milímetros.

5- Linha média: analisa-se a discrepância da linha média em relação aos incisivos centrais inferiores, sendo que o grau de desvio determina o escore que será multiplicado por 3.

O valor do índice PAR é obtido após o somatório total dos resultados parciais de seus componentes.

O índice PAR também foi calculado nos modelos iniciais (PARI) e finais (PARF). 
TABELA 2 - Critérios de aplicação dos escores para os componentes do índice $\mathrm{PAR}^{85}$.

\begin{tabular}{|c|c|c|c|c|}
\hline & RELAÇÕES OCLUSAIS & GRAU DE DISCREPÂNCIA & ESCORE & PESO \\
\hline \multirow{5}{*}{$\begin{array}{l}\text { O } \\
C \\
L \\
U \\
S \\
\tilde{A} \\
O\end{array}$} & Relação ântero-posterior & Boa intercuspidação - Classe I, II ou III & 0 & \multirow{3}{*}{2} \\
\hline & Relação ântero-posterior & Menor que a metade da largura de um pré-molar & 1 & \\
\hline & Relação ântero-posterior & Metade da largura de um pré-molar & 2 & \\
\hline & Vertical & Nenhuma discrepância & 0 & \multirow{2}{*}{2} \\
\hline & Vertical & Mord. aberta post. De pelo menos 2 dentes e maior que $2 \mathrm{~mm}$ & 1 & \\
\hline \multirow{5}{*}{$\begin{array}{l}\mathbf{P} \\
\mathbf{O} \\
\mathbf{S} \\
\mathrm{T} \\
\mathrm{E} \\
\mathrm{R} \\
\mathbf{I} \\
\mathbf{O} \\
\mathrm{R}\end{array}$} & Transversal & Ausência de mordida cruzada & 0 & \multirow{5}{*}{2} \\
\hline & Transversal & Tendência à mordida cruzada & 1 & \\
\hline & Transversal & Apenas um dente em mordida cruzada & 2 & \\
\hline & Transversal & Mais de um dente em mordida cruzada & 3 & \\
\hline & Transversal & Mais de um dente em mordida cruzada vestibular & 4 & \\
\hline \multirow{10}{*}{$\begin{array}{l}T \\
R \\
E \\
S \\
P\end{array}$} & Positivo & $0-3 \mathrm{~mm}$ & 0 & \multirow{5}{*}{5} \\
\hline & Positivo & $3,1-5 \mathrm{~mm}$ & 1 & \\
\hline & Positivo & $5,1-7 \mathrm{~mm}$ & 2 & \\
\hline & Positivo & $7,1-9 \mathrm{~mm}$ & 3 & \\
\hline & Positivo & Maior do que $9 \mathrm{~mm}$ & 4 & \\
\hline & Negativo & Nenhuma discrepância & 0 & \\
\hline & Negativo & Um ou mais dentes topo-a-topo & 1 & \\
\hline & Negativo & Um único dente em mordida cruzada & 2 & 5 \\
\hline & Negativo & Dois dentes em mordida cruzada & 3 & \\
\hline & Negativo & Mais de dois dentes em mordida cruzada & 4 & \\
\hline $\mathbf{T}$ & Negativo & Não apresenta mordida aberta & 0 & \\
\hline $\begin{array}{l}\mathbf{R} \\
\mathbf{E}\end{array}$ & Negativo & Mordida aberta menor ou igual a $1 \mathrm{~mm}$ & 1 & \\
\hline $\begin{array}{r}\mathbf{S} \\
\mathbf{P}\end{array}$ & Negativo & Mordida aberta de 1,1 a 2 mm & 2 & 3 \\
\hline 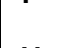 & Negativo & Mordida aberta de 2,1 a $3 \mathrm{~mm}$ & 3 & \\
\hline $\mathbf{E}$ & Negativo & Mordida aberta maior ou igual a $4 \mathrm{~mm}$ & 4 & \\
\hline $\begin{array}{l}\mathbf{R} \\
T\end{array}$ & Positivo & Menor ou igual a $1 / 3$ da coroa do incisivo inferior & 0 & \\
\hline i & Positivo & Maior do que $1 / 3$ e menor do que $2 / 3$ da coroa & 1 & 3 \\
\hline $\begin{array}{l}\text { C } \\
A\end{array}$ & Positivo & Maior do que $2 / 3$ da coroa do incisivo inferior & 2 & \\
\hline $\mathbf{L}$ & Positivo & Maior ou igual ao comprimento da coroa do inc. inf. & 3 & \\
\hline & & 0 a $1 \mathrm{~mm}$ de deslocamento & 0 & \\
\hline $\begin{array}{l}\mathbf{D} \\
\mathbf{E}\end{array}$ & APINHAMENTO & 1,1 a $2 \mathrm{~mm}$ de deslocamento & 1 & \\
\hline S & ESPAÇAMENTO & 2,1 a 4 mm de deslocamento & 2 & 1 \\
\hline 0 & IMPACCÕES & 4,1 a $8 \mathrm{~mm}$ de deslocamento & 3 & \\
\hline C & & Maior do que $8 \mathrm{~mm}$ de deslocamento & 4 & \\
\hline & & Dente impactado & & \\
\hline & & Coincidente ou desviada até $1 / 4$ da largura do incisivo & 0 & \\
\hline & LINHA MÉDIA & Desviada de $1 / 4$ à $1 / 2$ da largura da coroa do incisivo inferior & 1 & 3 \\
\hline & & Desviada mais da $1 / 2$ da largura da coroa do incisivo inferior & 2 & \\
\hline
\end{tabular}


*A fim de avaliar a melhora decorrente do tratamento ortodôntico, calculou-se a diferença entre os valores inicial e final tanto do IPT (DifIPT) como do PAR (DifPAR). A partir desta medida obteve-se também, os porcentuais de melhora expressos pelos índices IPT (PcIPT) e PAR $(\mathrm{PCPAR})^{9,85,86}$. O porcentual de melhora é um valor representativo da quantidade de melhora em relação à severidade inicial da má oclusão $($ PcIPT = DifIPT/IPTI X 100 e PcPAR = DifPAR/PARI X 100).

\subsubsection{3 Índice de eficiência do tratamento (let)}

Como a eficiência do tratamento encontra-se relacionada à obtenção dos melhores resultados em um menor tempo despendido, o grau de eficiência foi avaliado a partir de um índice definido pela razão entre o porcentual de melhora (PcIPT ou PcPAR) e o tempo de tratamento em meses ${ }^{7}$, sendo expresso pela seguinte equação: letIPT = PcIPT/Ttrat ou letPAR = PcPAR/Ttrat. Pode-se verificar que o porcentual de melhora apresenta uma relação direta com o índice de eficiência, enquanto que o tempo de tratamento mantém uma relação inversa com este índice. Desta forma, o valor do índice de eficiência aumenta na medida em que porcentuais de melhora maiores se associam a tempos de tratamento menores. 


\subsection{Análise estatística}

\subsubsection{Erro do método}

Para a determinação da confiabilidade dos resultados, quinze radiografias iniciais foram selecionadas ao acaso, traçadas e digitalizadas novamente, pela mesma pesquisadora. O erro intra-examinador também incluiu a realização de novas medidas e cálculos dos índices oclusais (IPT e PAR) de 20 modelos de gesso selecionados aleatoriamente. Determinou-se, desse modo, a diferença entre a primeira e segunda medição de cada telerradiografia e de cada modelo. Aplicou-se o teste $t$ de Student dependente, com o objetivo de avaliar a significância das diferenças apresentadas entre os dois traçados e as duas medições demonstrando, assim, o erro sistemático, de acordo com Houston ${ }^{49}$. Para a avaliação do erro casual, empregou-se a fórmula de Dahlberg ${ }^{28}$ $\left(\mathrm{Se}^{2}=\sum \mathrm{d}^{2} / 2 \mathrm{n}\right)$.

\subsubsection{Estatística}

Utilizou-se a estatística descritiva (média e desvio padrão) para todas as variáveis utilizadas. 
Para avaliar a compatibilidade dos grupos quanto à proporção dos tipos de má oclusão de Classe II (Classe II, $1^{\underline{a}}$ e $2^{\underline{a}}$ divisão), à severidade da discrepância ântero-posterior (Classe II completa, 3/4, 1/2 ou 1/4 de Classe II) e dos gêneros realizou-se o teste do Qui-Quadrado. O teste $t$ independente foi aplicado para verificar a compatibilidade entre os grupos em relação à severidade inicial da má oclusão (IPTI e PARI), às grandezas cefalométricas esqueléticas, dentárias e tegumentares e à idade inicial (Idadel).

O teste $t$ independente também foi aplicado às variáveis IPTF, PARF, DifIPT, DifPAR, PcIPT, PcPAR, Ttrat, letIPT e letPAR.

Os índices oclusais IPT e PAR resultam de um somatório de escores dados a cada uma das diferentes características oclusais que compõem estes índices, sendo assim, propusemo-nos a avaliar a influência de cada um destes componentes sobre o valor final dos índices. Para viabilizar esta investigação, os pesos aplicados a cada um dos escores foram removidos. Uma vez que os pesos aplicados aos componentes do índice PAR podem ser removidos com maior facilidade do que os incorporados ao IPT, apenas para o índice PAR foi realizada esta avaliação. O índice PAR foi desmembrado em seus diversos componentes e, em seguida, os pesos, inicialmente aplicados, foram removidos. A análise de regressão múltipla, aplicada aos diversos componentes do índice PAR possibilitou avaliar a influência de cada um dos componentes sobre o somatório final dos escores ${ }^{78}$, enquanto que o teste de Mann-Whitney foi utilizado para comparação intergrupos dos 
escores dados a cada um dos componentes do índice PAR. O teste de Mann-Whitney foi aplicado pois ao desmembrar o índice PAR em seus diversos componentes e remover os pesos referentes a cada um deles, observou-se que os valores fracionados dos escores não apresentavam, de acordo com o teste de Kolmogorov-Smirnov, uma distribuição normal, justificando a utilização de um teste não paramétrico.

O teste de correlação de Pearson foi aplicado para avaliar o grau de correlação entre os resultados oclusais obtidos ao final do tratamento (IPTF e PARF) e entre os porcentuais de melhora (PcIPT e PcPAR).

Considerou-se estatisticamente significantes resultados com valor de $p<0,05$.

Os testes foram aplicados por meio do programa Statistica for Windows $6.0^{3}$.

\footnotetext{
${ }^{3}$ Stat Soft Inc.
} 
5 Resultados 


\section{RESULTADOS}

As tabelas 3 e 4 apresentam os resultados do teste $t$ dependente e da fórmula de Dahlberg ${ }^{28}$, utilizados para estimar os erros sistemáticos e casuais, respectivamente, aplicados às variáveis cefalométricas (tabela 3) e aos índices oclusais IPT e PAR (tabela 4).

A avaliação da compatibilidade entre os grupos em relação às características cefalométricas foi realizada por meio do teste $t$ independente e encontra-se descrita na tabela 5. Enquanto que as proporções entre os gêneros (tabela 6), entre os tipos de má oclusão de Classe II (Classe II $1^{\underline{a}}$ divisão e Classe II $2^{-}$divisão - tabela 7) e entre os graus de discrepância ântero-posterior (tabela 8) foram avaliados pelo teste do Qui-Quadrado.

A compatibilidade entre os grupos em relação à idade inicial, realizada pelo teste $t$ independente encontra-se descrita na tabela 9. $\mathrm{Na}$ mesma tabela, também pode-se verificar os resultados do teste $t$ independente para a comparação dos grupos 1 e 2 quanto às variáveis: IPTI, PARI, IPTF, PARF, DifIPT, DifPAR, PcIPT, PcPAR, Ttrat (meses), Ttrat (anos), letIPT e letPAR.

Os resultados da análise de regressão linear múltipla (tabela 10), considerando-se o valor final do índice PAR como variável dependente, demonstram o grau de participação dos componentes do índice PAR na variação do valor final deste índice. A tabela 11 descreve a comparação 
intergrupos dos escores finais de cada um dos componentes do índice PAR, realizado pelo teste não paramétrico de Mann-Whitney.

O grau de correlação entre os resultados oclusais finais (IPTF e PARF) e entre os porcentuais de melhora (PcIPT e PcPAR), avaliados pelo teste de correlação de Pearson, encontram-se descritos na tabela 12.

Os resultados foram considerados estatisticamente significantes quando o valor de $p<0,05$. 
TABELA 3 - Resultados do teste $t$ dependente e da fórmula de Dahlberg ${ }^{28}$, aplicados às variáveis cefalométricas para estimar os erros sistemáticos e casuais, respectivamente.

\begin{tabular}{|c|c|c|c|c|c|c|}
\hline \multirow{2}{*}{ Variáveis } & \multicolumn{2}{|c|}{ 1을ado $(n=15)$} & \multicolumn{2}{|c|}{$2^{\circ}$ Traçado $(n=15)$} & \multirow{2}{*}{$\mathbf{p}$} & \multirow{2}{*}{ Dahlberg } \\
\hline & média & d.p. & média & d.p. & & \\
\hline \multicolumn{7}{|c|}{ COMPONENTE MAXILAR } \\
\hline SNA ( $\left.{ }^{0}\right)$ & 82,92 & 3,25 & 82,82 & 3,16 & 0,7587 & 0,7912 \\
\hline Co-A (mm) & 85,64 & 6,03 & 85,74 & 5,80 & 0,7518 & 0,8236 \\
\hline A-Nperp (mm) & 1,44 & 2,93 & 1,10 & 3,21 & 0,1238 & 0,5997 \\
\hline \multicolumn{7}{|c|}{ COMPONENTE MANDIBULAR } \\
\hline SNB ( $\left.{ }^{0}\right)$ & 77,75 & 2,80 & 77,64 & 2,83 & 0,6353 & 0,6236 \\
\hline Co-Gn (mm) & 108,04 & 6,03 & 108,01 & 6,04 & 0,9090 & 0,7582 \\
\hline Go-Gn (mm) & 70,06 & 4,35 & 70,54 & 4,49 & 0,1663 & 0,9206 \\
\hline Co-Go (mm) & 51,92 & 3,67 & 51,56 & 3,58 & 0,3507 & 1,0377 \\
\hline Pog-Nperp (mm) & $-4,24$ & 4,16 & $-4,62$ & 4,45 & 0,2478 & 0,8606 \\
\hline \multicolumn{7}{|c|}{ RELAÇÃO ENTRE MAXILA E MANDÍBULA } \\
\hline ANB ( & 5,19 & 1,54 & 5,17 & 1,61 & 0,8610 & 0,2972 \\
\hline WITS (mm) & 3,96 & 2,01 & 3,83 & 1,93 & 0,6194 & 0,7009 \\
\hline Co-A/Co-Gn (mm) & 79,26 & 2,71 & 79,38 & 2,43 & 0,5968 & 0,5927 \\
\hline \multicolumn{7}{|c|}{ PADRÃO DE CRESCIMENTO } \\
\hline FMA & 25,93 & 4,83 & 26,08 & 5,24 & 0,6301 & 0,8312 \\
\hline SN.GoGn & 32,46 & 5,89 & 32,21 & 6,11 & 0,4229 & 0,8314 \\
\hline SN.PP & 6,3 & 4,16 & 6,26 & 4,01 & 0,8437 & 0,5278 \\
\hline AFAl & 64,71 & 5,00 & 64,46 & 5,04 & 0,3086 & 0,6592 \\
\hline \multicolumn{7}{|c|}{ COMPONENTE DENTOALVEOLAR SUPERIOR } \\
\hline 1.PP ( ) & 108,36 & 6,02 & 108,60 & 6,72 & 0,7313 & 1,7700 \\
\hline 1.NA ( $\left.0^{0}\right)$ & 19,17 & 7,93 & 19,50 & 8,21 & 0,5774 & 1,5326 \\
\hline 1-NA (mm) & 3,20 & 2,61 & 3,14 & 2,43 & 0,7452 & 0,4273 \\
\hline 1-ENAperp (mm) & $-2,92$ & 2,46 & $-2,85$ & 2,71 & 0,8428 & 0,8744 \\
\hline 1-PP (mm) & 28,22 & 2,48 & 28,13 & 2,60 & 0,5338 & 0,3646 \\
\hline 6-PP (mm) & 22,38 & 2,38 & 22,30 & 2,41 & 0,5665 & 0,3953 \\
\hline 6-ENAperp (mm) & $-28,98$ & 2,22 & $-28,90$ & 2,09 & 0,8356 & 1,08464 \\
\hline \multicolumn{7}{|c|}{ COMPONENTE DENTOALVEOLAR INFERIOR } \\
\hline IMPA ( & 94,20 & 4,06 & 94,52 & 4,41 & 0,4727 & 1,1937 \\
\hline 1.NB ( & 26,51 & 5,88 & 26,62 & 6,15 & 0,8221 & 1,2347 \\
\hline 1-NB (mm) & 5,37 & 2,67 & 5,04 & 2,61 & 0,0090 & 0,3674 \\
\hline 1-PogPerp (mm) & $-9,72$ & 2,88 & $-9,61$ & 2,89 & 0,6605 & 0,6730 \\
\hline 1-GoMe (mm) & 40,12 & 2,90 & 39,56 & 2,92 & 0,0029 & 0,5721 \\
\hline 6-GoMe (mm) & 29,65 & 2,28 & 29,44 & 2,28 & 0,4160 & 0,6685 \\
\hline 6-PogPerp (mm) & $-29,38$ & 2,24 & $-29,12$ & 2,54 & 0,3104 & 0,6789 \\
\hline \multicolumn{7}{|c|}{ RELAÇÕES DENTÁRIAS } \\
\hline $\mathrm{TH}(\mathrm{mm})$ & 4,45 & 1,20 & 4,70 & 1,13 & 0,0751 & 0,3816 \\
\hline $\mathrm{THO}(\mathrm{mm})$ & 5,30 & 1,26 & 5,49 & 1,17 & 0,1191 & 0,3371 \\
\hline TV (mm) & 4,80 & 1,97 & 4,58 & 2,03 & 0,0253 & 0,2798 \\
\hline Rel. molar (mm) & 1,09 & 0,86 & 1,18 & 0,91 & 0,5880 & 0,4191 \\
\hline Rel. molar ocl (mm) & $-0,13$ & 0,81 & $-0,18$ & 0,83 & 0,5855 & 0,2556 \\
\hline \multicolumn{7}{|c|}{ PERFIL ÓSSEO X PERFIL TEGUMENTAR } \\
\hline NAPog $\left(^{0}\right)$ & 8,04 & 4,04 & 7,96 & 4,52 & 0,8008 & 0,8250 \\
\hline Conv. Teg. $\left({ }^{0}\right)$ & 15,80 & 4,28 & 16,17 & 4,23 & 0,2127 & 0,8012 \\
\hline Âng. Nasolabial ( $\left.{ }^{0}\right)$ & 101,85 & 15,65 & 103,98 & 13,12 & 0,1451 & 3,9449 \\
\hline H-nariz (mm) & 2,56 & 4,01 & 3,08 & 3,56 & 0,0545 & 0,7422 \\
\hline Ls-E (mm) & $-1,46$ & 2,24 & $-1,8$ & 1,96 & 0,0454 & 0,4750 \\
\hline Li-E (mm) & $-0,31$ & 3,29 & $-0,36$ & 3,28 & 0,8027 & 0,4861 \\
\hline Ls-APog (mm) & 18,27 & 1,90 & 17,91 & 2,17 & 0,1567 & 0,6855 \\
\hline Li-APog (mm) & 14,61 & 2,53 & 14,42 & 2,55 & 0,4283 & 0,6196 \\
\hline
\end{tabular}


TABELA 4 - Resultados do teste $t$ dependente e da fórmula de Dahlberg ${ }^{28}$, aplicados aos índices oclusais IPT e PAR para estimar os erros sistemáticos e casuais, respectivamente.

\begin{tabular}{l|c|c|c|c|c|c}
\hline \multirow{2}{*}{ Índices oclusais } & \multicolumn{2}{|c|}{$\mathbf{1}^{\mathbf{a}}$ Medição } & \multicolumn{2}{c|}{$\mathbf{2}^{\mathbf{a}}$ Medição } & \multirow{2}{*}{$\mathbf{p}$} & \multirow{2}{*}{ Dahlberg } \\
\cline { 2 - 5 } & média & d.p. & média & d.p. & & \\
\hline IPT & 3,65 & 2,79 & 3,58 & 2,80 & 0,5263 & 0,3234 \\
\hline PAR & 11 & 7,00 & 11,25 & 7,09 & 0,1350 & 0,5244 \\
\hline
\end{tabular}


TABELA 5 - Resultados do teste $t$ independente para avaliar a compatibilidade entre os grupos quanto às variáveis cefalométricas.

\begin{tabular}{|c|c|c|c|c|c|}
\hline \multirow[t]{2}{*}{ Variáveis } & \multicolumn{2}{|c|}{$\begin{array}{l}\text { GRUPO } 1 \text { ( } n=22) \\
\text { (Pendulum) }\end{array}$} & \multicolumn{2}{|c|}{$\begin{array}{l}\text { GRUPO } 2(n=26) \\
\text { (Extrações) }\end{array}$} & \multirow[t]{2}{*}{$\mathbf{p}$} \\
\hline & média & d.p. & média & d.p. & \\
\hline \multicolumn{6}{|c|}{ COMPONENTE MAXILAR } \\
\hline SNA ( $\left.{ }^{0}\right)$ & 82,75 & 3,16 & 81,17 & 3,72 & 0,1254 \\
\hline Co-A (mm) & 85,99 & 5,21 & 85,92 & 6,63 & 0,9691 \\
\hline A-Nperp (mm) & 1,31 & 3,03 & $-0,63$ & 4,00 & 0,0680 \\
\hline \multicolumn{6}{|c|}{ COMPONENTE MANDIBULAR } \\
\hline SNB ( $\left(^{0}\right)$ & 78,08 & 2,76 & 76,94 & 2,61 & 0,1493 \\
\hline Co-Gn (mm) & 108,34 & 5,21 & 108,39 & 6,60 & 0,9786 \\
\hline Go-Gn (mm) & 70,58 & 4,23 & 70,06 & 4,83 & 0,6977 \\
\hline Co-Go (mm) & 52,30 & 3,62 & 51,12 & 4,55 & 0,3329 \\
\hline Pog-Nperp (mm) & $-3,53$ & 4,76 & $-6,86$ & 6,10 & 0,0431 \\
\hline \multicolumn{6}{|c|}{ RELAÇÃO ENTRE MAXILA E MANDÍBULA } \\
\hline ANB ( $\left(^{0}\right.$ & 4,68 & 1,60 & 4,23 & 2,56 & 0,4778 \\
\hline WITS (mm) & 3,39 & 2,31 & 4,70 & 2,20 & 0,0505 \\
\hline Co-A/Co-Gn (mm) & 79,36 & 2,39 & 79,28 & 3,98 & 0,9287 \\
\hline \multicolumn{6}{|c|}{ PADRÃO DE CRESCIMENTO } \\
\hline FMA & 24,71 & 5,41 & 26,53 & 4,91 & 0,2296 \\
\hline SN.GoGn & 31,32 & 6,04 & 32,57 & 4,82 & 0,4284 \\
\hline SN.PP & 6,41 & 3,80 & 4,94 & 2,88 & 0,1343 \\
\hline AFAI & 63,61 & 4,71 & 64,79 & 5,40 & 0,4292 \\
\hline \multicolumn{6}{|c|}{ COMPONENTE DENTOALVEOLAR SUPERIOR } \\
\hline 1.PP ( $\left.{ }^{0}\right)$ & 108,98 & 6,44 & 114,10 & 8,57 & 0,0258 \\
\hline 1.NA ( $\left(^{0}\right)$ & 19,83 & 7,79 & 27,97 & 9,68 & 0,0027 \\
\hline 1-NA (mm) & 3,44 & 2,43 & 7,21 & 4,10 & 0,0004 \\
\hline 1-ENAperp (mm) & $-2,46$ & 2,66 & 0,74 & 3,45 & 0,0008 \\
\hline 1-PP (mm) & 27,86 & 2,39 & 28,90 & 3,15 & 0,2095 \\
\hline 6-PP (mm) & 22,16 & 2,14 & 24,08 & 2,77 & 0,0111 \\
\hline 6-ENAperp (mm) & $-28,68$ & 2,10 & $-26,81$ & 2,37 & 0,0063 \\
\hline \multicolumn{6}{|c|}{ COMPONENTE DENTOALVEOLAR INFERIOR } \\
\hline IMPA ( ) & 94,71 & 4,72 & 93,58 & 5,89 & 0,4719 \\
\hline 1.NB $\left(0^{\circ}\right)$ & 26,16 & 5,22 & 25,15 & 6,29 & 0,5543 \\
\hline $1-\mathrm{NB}(\mathrm{mm})$ & 4,93 & 2,38 & 4,91 & 2,43 & 0,9813 \\
\hline 1-PogPerp (mm) & $-9,17$ & 2,86 & $-10,66$ & 2,98 & 0,0870 \\
\hline 1-GoMe (mm) & 39,49 & 2,66 & 38,95 & 3,08 & 0,5255 \\
\hline 6-GoMe (mm) & 29,41 & 2,14 & 27,93 & 2,35 & 0,0284 \\
\hline 6-PogPerp (mm) & $-29,04$ & 2,12 & $-30,71$ & 2,28 & 0,0122 \\
\hline \multicolumn{6}{|c|}{ RELAÇÕES DENTÁRIAS } \\
\hline TH (mm) & 4,45 & 1,20 & 7,62 & 2,62 & 0,0000 \\
\hline $\mathrm{THO}(\mathrm{mm})$ & 5,29 & 1,28 & 8,10 & 2,71 & 0,0000 \\
\hline TV $(\mathrm{mm})$ & 4,88 & 1,85 & 4,11 & 2,74 & 0,2668 \\
\hline Rel. molar (mm) & 0,93 & 0,85 & 3,80 & 0,73 & 0,0000 \\
\hline Rel. molar ocl (mm) & $-0,21$ & 0,83 & 2,85 & 0,68 & 0,0000 \\
\hline \multicolumn{6}{|c|}{ PERFIL ÓSSEO X PERFIL TEGUMENTAR } \\
\hline NAPog ( ) & 7,04 & 3,81 & 6,12 & 6,46 & 0,5595 \\
\hline Conv. Teg. $\left({ }^{0}\right)$ & 15,40 & 4,04 & 17,67 & 6,05 & 0,1406 \\
\hline Âng. Nasolabial ( $\left.{ }^{0}\right)$ & 103 & 13,94 & 111,51 & 16,75 & 0,0647 \\
\hline H-nariz $(\mathrm{mm})$ & 2,86 & 3,52 & 3,56 & 3,55 & 0,5046 \\
\hline Ls-E (mm) & $-1,65$ & 1,99 & $-2,11$ & 2,25 & 0,4615 \\
\hline Li-E (mm) & $-0,46$ & 2,87 & $-0,07$ & 2,76 & 0,6337 \\
\hline Ls-APog (mm) & 18,37 & 1,62 & 18,88 & 2,84 & 0,4564 \\
\hline Li-APog $(\mathrm{mm})$ & 14,68 & 2,16 & 15,91 & 2,58 & 0,0897 \\
\hline
\end{tabular}


TABELA 6 - Resultado do teste Qui-Quadrado para avaliar a compatibilidade dos grupos quanto à proporção entre os gêneros.

\begin{tabular}{l|c|c|c}
\hline \multicolumn{1}{c|}{ Gêneros } & M & F & Total \\
\hline Grupos & 7 & 15 & 22 \\
\hline Grupo 1 (Pendulum) & 14 & 12 & 26 \\
\hline Grupo 2 (Extrações) & 21 & 27 & 48 \\
\hline Total & $\mathrm{gl}=1$ & \multicolumn{2}{c}{$\mathrm{p}=0,1253$} \\
\hline \multicolumn{2}{c|}{}
\end{tabular}

TABELA 7 - Resultado do teste Qui-Quadrado para avaliar a compatibilidade dos grupos quanto à proporção dos tipos de má oclusão de Classe II.

\begin{tabular}{|c|c|c|c|}
\hline Grupos Má oclusão & $\mathrm{Cl} \| 1^{\underline{a}}$ & $\mathrm{Cl} \| 2^{\underline{a}}$ & Total \\
\hline Grupo 1 (Pendulum) & 19 & 3 & 22 \\
\hline Grupo 2 (Extrações) & 22 & 4 & 26 \\
\hline Total & 41 & 7 & 48 \\
\hline$x^{2}=0,03$ & $g \mid=1$ & & 8642 \\
\hline
\end{tabular}

TABELA 8 - Resultado do teste Qui-Quadrado para avaliar a compatibilidade dos grupos quanto à discrepância ântero-posterior.

\begin{tabular}{|c|c|c|c|c|c|}
\hline Grupos & $\begin{array}{c}\mathrm{Cl} \text { II } \\
\text { completa }\end{array}$ & $3 / 4 \mathrm{Cl} \mathrm{II}$ & $1 / 2 \mathrm{Cl} \mathrm{II}$ & $1 / 4 \mathrm{Cl} \mathrm{II}$ & Total \\
\hline Grupo 1 (Pendulum) & 6 & 6 & 6 & 4 & 22 \\
\hline Grupo 2 (Extrações) & 26 & 0 & 0 & 0 & 26 \\
\hline Total & 32 & 6 & 6 & 4 & 48 \\
\hline$x^{2}=28,36$ & \multicolumn{3}{|c|}{$g \mathrm{~g}=3$} & \multicolumn{2}{|c|}{$p=0,0000$} \\
\hline
\end{tabular}


TABELA 9 - Resultados do teste $t$ independente aplicados às variáveis estudadas, nos grupos 1 e 2 .

\begin{tabular}{l|c|c|c|c|c}
\hline \multirow{2}{*}{ Variáveis } & \multicolumn{2}{|c|}{$\begin{array}{c}\text { GRUPO 1 (n=22) } \\
\text { (Pendulum) }\end{array}$} & \multicolumn{2}{c|}{$\begin{array}{c}\text { GRUPO 2 } \mathbf{( n = 2 6 )} \\
\text { (Extrações) }\end{array}$} & \multirow{2}{*}{$\mathbf{p}$} \\
\cline { 2 - 5 } & média & d.p. & média & d.p. & \\
\hline Idadel & 14,44 & 1,85 & 13,66 & 0,91 & 0,0626 \\
\hline IPTI & 6,05 & 1,63 & 7,89 & 1,18 & 0,0000 \\
\hline PARI & 15,91 & 5,12 & 24,62 & 7,58 & 0,0000 \\
\hline IPTF & 0,84 & 1,12 & 0,73 & 0,70 & 0,6832 \\
\hline PARF & 4,23 & 3,74 & 2,92 & 3,16 & 0,1968 \\
\hline DifIPT & 5,21 & 1,43 & 7,16 & 1,35 & 0,0000 \\
\hline DifPAR & 11,68 & 5,50 & 21,69 & 8,60 & 0,0000 \\
\hline PcIPT & 87,71 & 14,79 & 90,71 & 9,01 & 0,3933 \\
\hline PcPAR & 72,82 & 21,83 & 86,46 & 15,79 & 0,0158 \\
\hline Ttrat (meses) & 45,70 & 12,18 & 23,01 & 6,01 & 0,0000 \\
\hline Ttrat (anos) & 3,81 & 1,01 & 1,92 & 0,50 & 0,0000 \\
\hline letIPT & 2,03 & 0,61 & 4,20 & 1,19 & 0,0000 \\
\hline letPAR & 1,69 & 0,70 & 4,02 & 1,37 & 0,0000 \\
\hline
\end{tabular}

TABELA 10 - Resultados da análise de regressão linear múltipla, considerando o valor final do índice PAR como variável dependente.

\begin{tabular}{c|c|c|c|c}
\hline $\begin{array}{c}\text { Componentes do índice } \\
\text { PAR }\end{array}$ & $\begin{array}{c}\text { Coeficiente parcial } \\
\text { de regressão }\end{array}$ & $\begin{array}{c}\text { Erro } \\
\text { padrão }\end{array}$ & $\mathbf{t}$ & $\mathbf{p}$ \\
\hline Oclusão posterior (OP) & 0,6416 & 0,0547 & 11,7331 & 0,0000 \\
\hline Trespasse horizontal (TH) & 0,2292 & 0,0777 & 2,9489 & 0,0052 \\
\hline Trespasse vertical (TV) & 0,3207 & 0,0657 & 4,8783 & 0,0000 \\
\hline Apinhamento (Apinh) & 0,1879 & 0,0529 & 3,5484 & 0,0010 \\
\hline Linha média (LM) & 0,1935 & 0,0663 & 2,9177 & 0,0056 \\
\hline
\end{tabular}

$$
\mathrm{R}^{2}=0,8749
$$

$$
\begin{gathered}
\text { PAR }_{\text {FINAL }}=0,17(\text { constante })+0,64(\mathrm{OP})+0,23(\mathrm{TH})+0,32(\mathrm{TV})+ \\
0,19(\text { Apinh })+0,19(\mathrm{LM})
\end{gathered}
$$


TABELA 11 - Resultados do teste não paramétrico de Mann-Whitney entre os escores finais de cada um dos componentes do índice PAR dos grupos 1 e 2.

\begin{tabular}{|c|c|c|c|c|c|c|c|}
\hline \multirow[t]{2}{*}{$\begin{array}{l}\text { Componentes } \\
\text { do índice PAR }\end{array}$} & \multicolumn{3}{|c|}{$\begin{array}{c}\text { Grupo } 1(n=22) \\
\text { (Pendulum) }\end{array}$} & \multicolumn{3}{|c|}{$\begin{array}{c}\text { Grupo } 2(n=26) \\
\text { (Extrações) }\end{array}$} & \multirow[t]{2}{*}{ p } \\
\hline & Mediana & $\begin{array}{c}1^{\circ} \\
\text { Quartil } \\
(25 \%)\end{array}$ & $\begin{array}{c}3^{0} \\
\text { Quartil } \\
(75 \%)\end{array}$ & Mediana & $\begin{array}{c}1^{\circ} \\
\text { Quartil } \\
(25 \%)\end{array}$ & $\begin{array}{c}3^{\circ} \\
\text { Quartil } \\
(75 \%)\end{array}$ & \\
\hline $\begin{array}{c}\text { Oclusão } \\
\text { posterior(OP) }\end{array}$ & 1,00 & 1,00 & 2,00 & 1,00 & 0,00 & 2,00 & 0,1283 \\
\hline $\begin{array}{c}\text { Trespasse } \\
\text { horizontal(TH) }\end{array}$ & 0,00 & 0,00 & 0,00 & 0,00 & 0,00 & 0,00 & 0,9340 \\
\hline $\begin{array}{c}\text { Trespasse } \\
\text { vertical (TV) }\end{array}$ & 0,00 & 0,00 & 0,00 & 0,00 & 0,00 & 0,00 & 0,4882 \\
\hline $\begin{array}{c}\text { Apinhamento } \\
\text { (Apinh) }\end{array}$ & 0,00 & 0,00 & 0,00 & 0,00 & 0,00 & 0,00 & 0,8523 \\
\hline $\begin{array}{l}\text { Linha média } \\
\text { (LM) }\end{array}$ & 0,00 & 0,00 & 0,00 & 0,00 & 0,00 & 0,00 & 0,7563 \\
\hline
\end{tabular}

TABELA 12 - Resultados do teste de correlação de Pearson aplicado às variáveis IPTF e PARF e PcIPT e PcPAR.

\begin{tabular}{l|c|c}
\hline Variáveis & $\mathbf{r}$ & $\mathbf{p}$ \\
\hline IPTF X PARF & 0,7380 & $\mathbf{0 , 0 0 0 0}$ \\
\hline PcIPT X PcPAR & 0,6006 & $\mathbf{0 , 0 0 0 0}$ \\
\hline
\end{tabular}


6 Discussão 


\section{DISCUSSÃO}

Para facilitar a interpretação dos resultados obtidos, considerandose as variáveis envolvidas neste estudo, a discussão foi realizada na seguinte seqüência:

6.1 Amostra utilizada

6.2 Metodologia aplicada

6.3 Precisão da metodologia

6.4 Resultados obtidos

6.4.1 Compatibilidade dos grupos

6.4.2 Resultados oclusais

6.4.3 Tempo de tratamento

6.4.4 A eficiência do tratamento ortodôntico

6.5 Avaliação dos índices oclusais

6.6 Implicações clínicas

6.7 Sugestões para novos trabalhos.

\subsection{Amostra utilizada}

Apenas pacientes portadores da má oclusão de Classe II foram selecionados. A seleção da amostra baseou-se principalmente nos 
protocolos de tratamento avaliados no presente estudo: utilização do aparelho Pendulum e extrações de dois pré-molares superiores.

Os casos tratados com o aparelho Pendulum e replanejados, alterando-se o tratamento para as extrações de dois pré-molares superiores, foram excluídos a fim de não interferirem na duração do tratamento ortodôntico ${ }^{7,70,71}$.

Os pacientes apresentavam todos os dentes permanentes até os primeiros molares irrompidos e ausências de supranumerários, uma vez que a extração de dentes permanentes e a existência de supranumerários podem alterar o desenvolvimento normal da oclusão e exigir uma mecânica ortodôntica diferenciada.

Ao avaliar a idade média inicial dos pacientes tratados pelo Pendulum (14,44 anos) pode surgir a questão em relação à presença dos segundos molares permanentes. Todos os pacientes deste grupo apresentavam os segundos molares permanentes irrompidos. Este fato dificilmente acarretaria em alguma alteração dos resultados observados, pois diversos estudos ${ }^{19,25,37,59}$ comprovaram que a distalização dos primeiros molares pode ser obtida antes ou após a erupção dos segundos molares sem que ocorram alterações significantes nos resultados obtidos.

Os pacientes selecionados também não apresentaram dentes impactados e anomalias significativas relacionadas ao tamanho e/ou a forma dos dentes (macrodente, microdente, dente coníode), capazes de interferir no grau de complexidade do tratamento por uma razão inerente ao posicionamento ou à anatomia dentária. As pequenas discrepâncias 
do tamanho dentário, detectadas apenas pela análise de Bolton, não foram consideradas.

Os tratamentos foram realizados com aparelho fixo pela mecânica de Edgewise, utilizando-se acessórios do tipo padrão ou pré-ajustado (Roth), o que permite que em ambos os grupos seja avaliada a qualidade da finalização do tratamento ortodôntico, visto que os índices oclusais utilizados no presente estudo avaliam não apenas a oclusão posterior, mas também o trespasse horizontal, o trespasse vertical, o alinhamento dentário e a linha média.

Outro pré-requisito para a inclusão na amostra consistiu na existência da documentação ortodôntica completa, uma vez que os modelos de gesso foram utilizados para as avaliações oclusais, as telerradiografias iniciais para a verificação da compatibilidade inicial entre os grupos e os dados das fichas clínicas para estabelecer a idade inicial, o gênero e o tempo de tratamento.

Desta forma, a amostra foi constituída por 48 pacientes, sendo 22 tratados por meio do aparelho Pendulum por apenas dois alunos do curso de pós-graduação (stricto sensu) da disciplina de Ortodontia da Faculdade de Odontologia de Bauru - Universidade de São Paulo e 26 pacientes tratados por meio das extrações de dois pré-molares superiores tratados por alunos dos cursos de pós-graduação (lato e stricto sensu) da disciplina de Ortodontia da referida instituição. 


\subsection{Metodologia aplicada}

Dos prontuários ortodônticos, utilizou-se o registro do nome do paciente, do gênero, da data de nascimento, dos protocolos de tratamento propostos, das datas do início e do final do tratamento. Estes dados permitiram: a compatibilização entre os grupos em relação ao gênero e à idade inicial; a divisão dos grupos de acordo com o tratamento estabelecido e o cálculo do tempo de tratamento.

As telerradiografias em norma lateral iniciais foram utilizadas para a a compatibilização inicial entre os grupos em relação às grandezas cefalométricas das bases ósseas, do padrão de crescimento e perfis ósseo e tegumentar. Isto porque os dois protocolos de tratamento encontram-se indicados para más oclusões de Classe II com características morfológicas semelhantes.

Nos modelos de gesso, verificou-se a severidade inicial da má oclusão (Classe II completa, 3/4 de Classe II, 1/2 Classe II ou 1/4 de Classe II) e realizou-se as avaliações oclusais por meio dos índices PAR e IPT.

Estes índices foram selecionados pela comprovada validade que possuem em expressar quantitativamente uma determinada condição oclusal, pela confiabilidade e reprodutibilidade que imprimem aos resultados, por terem sido elaborados e amplamente utilizados com o propósito de avaliarem os resultados do tratamento ortodôntico e por serem de aplicação simples e objetiva ${ }^{7,9,14,31,45,51,52,66,84-86,99,100}$. 
Os índices IPT e PAR possibilitam não somente a avaliação dos resultados como também o grau de severidade da má oclusão ao início do tratamento. Desta forma, torna-se possível avaliar a quantidade e o porcentual de melhora obtidos em cada grupo ao final do tratamento e a compatibilidade dos grupos em relação à severidade inicial ${ }^{7,9,31,51,85,86}$.

O grau de eficiência do tratamento foi calculado a partir do porcentual de melhora, evidenciado pelos índices IPT e PAR, em relação ao tempo de tratamento ${ }^{7}$.

Visto que o índice PAR não considera a presença de apinhamento ântero-inferior, poderia ser questionado se esta condição não influenciaria os resultados obtidos caso os grupos diferissem quanto a esta variável. Entretanto, devido à ausência de extrações no arco inferior em ambos os grupos e mediante os resultados obtidos por BARROS ${ }^{7}$, onde o autor observou uma semelhança no grau de apinhamento ântero-inferior ao comparar o tratamento da Classe II por meio das extrações de dois prémolares e do tratamento sem extrações, não se julgou necessário realizar, no presente estudo, esta avaliação. Mesmo porque este item já foi considerado no planejamento inicial dos casos.

Como os pacientes tratados por meio das extrações de dois prémolares superiores finalizam com os molares em relação de Classe II 7,14,15,30,44,51-53,58,70,77,94 e o índice IPT atribui a relação molar de Classe II uma constante de valor numérico elevado, caracterizando uma condição oclusal indesejável, considerou-se a relação molar de Classe II obtida ao final do tratamento neste grupo como normal. Esta alteração também foi 
realizada em estudos prévios devido a esta característica deste

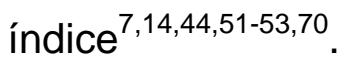

Os índices oclusais IPT e PAR resultam de um somatório de escores dados a cada uma das diferentes características oclusais que compõem estes índices. Apesar de avaliarem com fidelidade os resultados do tratamento ortodôntico, eles não especificam quais as características oclusais que mais contribuíram para as alterações observadas. Para viabilizar esta investigação, os pesos aplicados a cada um dos escores devem ser removidos. Uma vez que os pesos aplicados aos componentes do índice PAR podem ser removidos com maior facilidade do que os incorporados ao IPT, apenas para o índice PAR foi realizada esta avaliação. O índice PAR obtido ao final do tratamento (PARF) foi desmembrado em seus diversos componentes e, em seguida, os pesos, inicialmente aplicados, foram removidos. A análise de regressão múltipla, aplicada aos diversos componentes do índice PAR possibilitou avaliar a influência de cada um dos componentes sobre o somatório final dos escores ${ }^{48,78}$, enquanto que o teste de Mann-Whitney foi utilizado para comparação intergrupos dos escores dados a cada um dos componentes do índice PAR. O teste de Mann-Whitney foi aplicado, pois ao desmembrar o índice PAR em seus diversos componentes e remover os pesos referentes a cada um deles, observou-se que os valores fracionados dos escores não apresentavam, de acordo com o teste de Kolmogorov-Smirnov, uma distribuição normal, justificando a utilização de um teste não paramétrico. 
Como existem algumas diferenças em relação às características oclusais avaliadas pelos índices PAR e IPT, o teste de correlação de Pearson foi aplicado para possibilitar uma avaliação da sensibilidade destes índices na identificação dos desvios da oclusão em relação à normalidade e às alterações oclusais decorrentes do tratamento ortodôntico.

\subsection{Precisão da metodologia}

Previamente ao cálculo dos índices IPT e PAR, a pesquisadora foi calibrada por um ex-aluno $\left(\right.$ BARROS $\left.^{7}\right)$ do curso de pós-graduação da disciplina de Ortodontia da Faculdade de Odontologia de Bauru que utilizou as mesmas avaliações oclusais em sua dissertação para a obtenção do título de mestre em odontologia, área de concentração Ortodontia.

Após a calibração, para o cálculo dos índices IPT e PAR, as medições foram realizadas nos modelos de gesso pré e pós-tratamento com o auxílio de um paquímetro capaz de imprimir às medidas uma precisão de até 0,1 milímetro. Posteriormente as medidas foram transformadas em escores de acordo com as normas estabelecidas nas publicações originais de cada índice ${ }^{45,85}$.

Para a determinação da confiabilidade dos resultados, quinze radiografias iniciais foram selecionadas ao acaso, traçadas e digitalizadas 
novamente, pela mesma pesquisadora. $\mathrm{O}$ erro intra-examinador também incluiu a realização de novas medidas e cálculos dos índices oclusais (IPT e PAR) de 20 modelos de gesso selecionados aleatoriamente. Determinou-se, desse modo, a diferença entre a primeira e segunda medição de cada telerradiografia e de cada modelo. Aplicou-se o teste $t$ de Student dependente, com o objetivo de avaliar a significância das diferenças apresentadas entre os dois traçados e as duas medições demonstrando assim, o erro sistemático, de acordo com HOUSTON ${ }^{49}$. Para a avaliação do erro casual, empregou-se a fórmula de DAHLBERG ${ }^{28}$.

Os erros sistemáticos ocorrem quando uma medida é freqüentemente sub ou superestimada. De acordo com HOUSTON ${ }^{49}$, estes erros podem resultar de uma alteração na técnica de mensuração ou de uma tendenciosidade subconsciente do examinador em direcionar os resultados de acordo com as próprias expectativas. Os erros casuais são aqueles que ocorrem ocasionalmente e segundo HOUSTON ${ }^{49}$ encontram-se relacionados à dificuldade e à imprecisão na identificação ou definição de certos pontos. Os erros, quando significativos, podem afetar a confiabilidade dos resultados obtidos ${ }^{49}$.

$\mathrm{Na}$ avaliação da precisão da metodologia em relação às variáveis cefalométricas, admitiu-se, para a fórmula de DAHLBERG ${ }^{28}$, uma tolerância de $1,5^{\circ}$ para as grandezas angulares e de $1 \mathrm{~mm}$ para as lineares e para o teste $t$, o nível de significância foi de $5 \%$. Como pode ser observado na tabela 3, ocorreram 4 erros sistemáticos (1-NB, 1-GoMe, TV 
e Ls-E), porém com alterações menores do que 1 milímetro entre a primeira e a segunda medição e 5 erros casuais (Co-Go, 1.PP, 1.NA, 6ENAperp e ângulo nasolabial), sendo que as variações foram menores do que 1 milímetro e 1 grau entre as medições para 4 grandezas cefalométricas. Apenas para o ângulo nasolabial esta alteração foi maior $\left(2,13^{0}\right)$. Como a maioria dos erros obtidos apresentou uma variação menor do que 1 milímetro e 1 grau entre as medições, exceto para este ângulo, e considerando-se que os erros sistemáticos ocorreram em apenas 4 das 42 medidas $(9,5 \%)$, os resultados obtidos podem ser considerados confiáveis.

Provavelmente em função da fácil reprodutibilidade dos índices IPT e PAR e pela calibração previamente às medições, as avaliações oclusais não apresentaram nenhum erro sistemático e casual (tabela 4). 


\subsection{Resultados obtidos}

\subsubsection{Compatibilidade dos grupos}

Os grupos apresentaram-se compatíveis quanto à maioria das grandezas cefalométricas (tabela 5) relacionadas à maxila, à mandíbula, ao padrão de crescimento, aos componentes dentários inferiores e aos perfis ósseo e tegumentar, quanto aos gêneros (tabela 6), aos tipos de má oclusão de Classe II (tabela 7) e também à idade inicial (tabela 9). Entretanto, os grupos não foram compatíveis quanto à severidade inicial da má oclusão retratada pela discrepância ântero-posterior (tabela 8) e pelos valores iniciais dos índices IPT e PAR (tabela 9).

A compatibilidade inicial entre os grupos das grandezas cefalométricas relacionadas à maxila, à mandíbula (tamanho, posição e relacionamento entre as bases ósseas), ao padrão de crescimento, aos componentes dentários inferiores e aos perfis ósseo e tegumentar (tabela 5) reduz significantemente as críticas aos estudos não randomizados de que o protocolo de tratamento selecionado poderia ter sido influenciado pelas características iniciais do paciente ${ }^{17}$.

No estudo de BISHARA; CUMMINS; JAKOBSEN ${ }^{10}$ também não houve diferença entre os grupos tratados com e sem extração em relação às grandezas cefalométricas que caracterizam o relacionamento ântero- 
posterior entre as bases apicais (ANB e NAPog), padrão de crescimento e convexidade do perfil mole.

Como os gêneros apresentaram-se compatíveis (tabela 6), essa variável não influencia os resultados obtidos relacionados a algum tipo de dimorfismo sexual seja de maturação esquelética e ritmo de crescimento ou de níveis de colaboração, onde o gênero feminino demonstrou em diversos estudos a época de maturação mais precoce, o ritmo de crescimento mais acelerado ${ }^{12,72,111}$ e maior grau de cooperação durante o tratamento ${ }^{27,103}$.

Quanto à distribuição dos casos de Classe II 1a e $2^{\underline{a}}$ divisão, os grupos também apresentaram uma distribuição semelhante (tabela 7). Os casos de Classe II, $2^{\underline{a}}$ divisão foram incluídos em função da correção da discrepância ântero-posterior dos molares apresentar-se similar para a Classe II $1^{\underline{a}}$ e $2^{\underline{a}}$ divisão ${ }^{52,76}$. As distintas características oclusais destes dois tipos de Classe II ao início do tratamento também não geram comprometimento durante a aplicação dos índices oclusais, pois o maior escore aplicado ao trespasse horizontal, nos casos de Classe II $1^{\underline{a}}$ divisão é quantitativamente compensado pela maior severidade do trespasse vertical e do apinhamento presentes na Classe $2^{\underline{a}}$ divisão ${ }^{7,51}$. Desta forma, para os dois tipos de más oclusões, os índices mensurados tendem a ser semelhantes, indicando a equivalência dos dois tipos de Classe II quanto ao grau de severidade ${ }^{51}$. Assim, a inclusão destes casos não afeta os resultados obtidos. Em estudos anteriores, ao realizarem avaliações dos resultados oclusais obtidos por diferentes protocolos de tratamento, 
BARROS $^{7}$, BRAMBILLA ${ }^{14}$, JANSON et al. ${ }^{52}$ e JANSON et al. ${ }^{51}$ também incluíram alguns pacientes Classe II $2^{\underline{a}}$ divisão nas amostras avaliadas.

As idades iniciais apresentaram-se compatíveis (tabela 9). Este é um fator importante na avaliação da eficiência do tratamento uma vez que os resultados normalmente apresentam-se mais favoráveis para os grupos mais jovens. O crescimento mandibular pode alterar os resultados obtidos já que auxilia na correção da Classe ${ }^{4}{ }^{46}$. HARRIS; DYER; $V_{A D E N}{ }^{46}$ demonstraram que o crescimento mandibular em pacientes adolescentes (idade média inicial de 12,5 anos), do gênero feminino, portadoras da má oclusão de Classe II contribuiu em 70\% para a correção da relação molar sendo que a movimentação ortodôntica foi responsável pelos $30 \%$ restantes.

As diferenças entre os grupos em relação às grandezas cefalométricas que indicam o grau de protrusão e inclinação dos incisivos superiores (1.PP, 1.NA, 1-NA, 1-ENAperp - tabela 5) ao início do tratamento podiam ser esperadas uma vez que o uso do aparelho Pendulum causa uma perda de ancoragem anterior, com inclinação dos incisivos e aumento do trespasse horizontal ${ }^{19,20,25,35,37,60}$, sendo, portanto, não favorável a sua utilização nos casos com o trespasse horizontal já acentuado inicialmente ${ }^{109}$. Além disto, a má oclusão inicial apresentou-se mais severa para o grupo tratado por meio das extrações.

Os molares superiores apresentaram-se mais mesializados no grupo com extrações (6-ENAperp - tabela 5), enquanto que os inferiores encontravam-se mais distalizados no mesmo grupo (6-PogPerp - tabela 5) 
quando comparados ao posicionamento destes dentes no grupo tratado pelo Pendulum. Estes resultados associados a um maior valor cefalométrico para o trespasse horizontal reforçam a maior discrepância ântero-posterior inicial no grupo tratado por meio das exodontias dos prémolares superiores.

A severidade inicial da má oclusão não foi equiparada entre os grupos, pois o grupo 1 (tratado pelo distalizador Pendulum) foi composto por uma amostra de caráter prospectivo, onde não se estabeleceu um critério em relação à severidade inicial para a inclusão dos pacientes no grupo. No grupo 2 (tratados por meio das extrações de dois pré-molares superiores), todos os pacientes apresentavam uma Classe II bilateral completa. Os pacientes que compõem este grupo já foram avaliados em estudos anteriores ${ }^{7,14,51,53}$ realizados na disciplina de Ortodontia da Faculdade de Odontologia de Bauru - Universidade de São Paulo. Desta forma, os grupos não se apresentaram compatíveis quanto à severidade inicial da má oclusão, demonstrada pelas grandezas cefalométricas: 6ENAperp, 6-PogPerp, trespasse horizontal, trespasse horizontal oclusal, relação molar e relação molar oclusal e pelos valores iniciais do IPT, PAR (tabelas 5, 8 e 9). Os valores iniciais dos índices IPT e PAR maiores para o grupo tratado com as extrações estão de acordo com os resultados obtidos por GRACIANO ${ }^{44}$ e O'BRIEN et al. ${ }^{78}$, respectivamente. 


\subsubsection{Resultados oclusais}

Os valores finais do IPT e do PAR não apresentaram diferenças estatisticamente significantes na avaliação intergrupos, o que demonstra que os resultados oclusais obtidos foram semelhantes entre os grupos (tabela 9). De acordo com RICHMOND et al. ${ }^{85}$, quando o valor obtido para o índice PAR ao final do tratamento é menor ou igual a 5, considera-se a oclusão quase perfeita. Visto que os dois grupos apresentaram o índice PAR final menor do que 5 (Pendulum: 4,23 e extrações: 2,92) pode-se considerar que para ambos os protocolos de tratamento os casos foram bem finalizados.

Na comparação entre os grupos em relação à diferença entre os valores inicial e final tanto do IPT (DifIPT) como do PAR (DifPAR), o grupo tratado por meio das extrações dos pré-molares superiores apresentou valores significantemente maiores do que o grupo que utilizou o Pendulum (tabela 9). Este fato pode ser facilmente explicado pelos menores valores do IPT e do PAR ao início do tratamento no grupo tratado sem as extrações, enquanto que, ao final do tratamento, os índices oclusais apresentaram-se semelhantes entre os grupos (tabela 9).

O porcentual de melhora, representativo da quantidade de melhora em relação à severidade inicial da má oclusão, demonstrou diferenças entre os grupos apenas quando utilizado o índice PAR (PcPAR). O grupo tratado com as extrações superiores demonstrou uma maior redução do porcentual da má oclusão inicial do que o tratado por meio do aparelho 
Pendulum (tabela 9). O porcentual de melhora não apresentou diferença intergrupos quando utilizado o IPT. Uma possível explicação para a diferença entre os índices é a de que nos casos onde a relação molar final era de $1 / 4$ de Classe II, ao calcular o índice IPT, os pacientes foram enquadrados na coluna de neutro oclusão, que apresenta um menor peso. Enquanto que no cálculo do índice PAR, há um peso específico para esta quantidade de discrepância ântero-posterior. Como no Pendulum existiam mais pacientes que terminaram em $1 / 4$ de Classe II em relação ao grupo com extrações, possivelmente não se observou diferença no porcentual de melhora do IPT, pois os valores foram abrandados pela classificação na coluna de neutro oclusão.

\subsubsection{Tempo de tratamento}

Constatando que os valores finais do IPT e do PAR apresentaramse semelhantes entre os grupos e os graus de eficiência dos tratamentos significantemente diferente (tabela 9), o fator que influenciou na obtenção de um menor índice de eficiência para o grupo tratado por meio do Pendulum foi o tempo de tratamento.

O tempo de tratamento apresentou-se significantemente maior para o grupo que utilizou o aparelho Pendulum quando comparado ao grupo com extrações de dois pré-molares superiores (tabela 9). Enquanto o tempo de tratamento do grupo sem extrações foi de 45,7 meses $(3,81$ 
anos), o do grupo com as exodontias foi de 23,01 meses (1,92 anos). Esta diferença, provavelmente, encontra-se relacionada à necessidade da correção e posterior manutenção da relação molar no grupo tratado pelo distalizador intrabucal.

Apesar deste dispositivo possibilitar a distalização dos molares, a maioria dos autores demonstra uma inclinação excessiva destes dentes para distal. BUSSICK; McNAMARA JR ${ }^{19}$ observaram uma inclinação de $10,6^{0}$, GHOSH; NANDA ${ }^{37}$ de $8,4^{0}$, BYLOFF; DARENDELILER ${ }^{20}$ de $14,5^{0}$, CHAQUÉS-ASENSI; KALRA ${ }^{25}$ de $13,1^{0}$, FUZIY $^{35}$ de $12,66^{0}$ e BURKHARDT; MCNAMARA JR; BACCETTI ${ }^{17}$ de $10^{\circ}$. Com a modificação pela adição de uma dobra para a verticalização dos molares, BYLOFF et al. ${ }^{21}$ diminuíram esta inclinação para $6,1^{0}$, porém não conseguiram eliminá-la e aumentaram o tempo de uso do Pendulum em 10,9 semanas, o que resultou em um aumento do tempo de tratamento durante a fase de distalização de $64,1 \%$.

Esta inclinação para distal dos molares pode ocasionar uma recidiva do posicionamento destes dentes devido à impossibilidade de uma correta distribuição das forças mastigatórias e também à seqüência do tratamento ortodôntico, onde os dentes anteriores serão retraídos utilizando-se os molares como ancoragem ${ }^{109}$.

Esta inclinação dos molares impossibilita uma ancoragem efetiva para a retração anterior, necessitando-se, portanto de um reforço de ancoragem vigoroso durante a retração ${ }^{25}$. CHAQUÉS-ASENSI; KALRA ${ }^{25}$ ressaltam que métodos adicionais devem ser utilizados a fim de reforçar a 
ancoragem. Entre as opções destacam o uso do aparelho extrabucal nos primeiros molares superiores, molas de verticalização nos primeiros prémolares e uso de elásticos de Classe II.

Os artigos descrevem o distalizador Pendulum como um aparelho que exige mínima colaboração, porém a maioria só avaliou os resultados até a fase pós-distalização ${ }^{19-21,35,37,102}$, que realmente independe da colaboração do paciente. Porém, para finalizar o tratamento, é necessário corrigir a inclinação e retrair os dentes anteriores sem que ocorra a recidiva da relação molar. Desta forma, a colaboração torna-se necessária na utilização do aparelho extrabucal para promover a movimentação para distal das raízes ${ }^{17,37}$. Posteriormente à correção desta inclinação, o grande desafio é a retração anterior, mantendo-se a correção da relação molar obtida com a distalização, o que implica novamente em uma adequada cooperação do paciente no uso de aparelho extrabucal e elásticos de Classe $1 I^{5,19,25}$.

Desta forma, para a correção da discrepância ântero-posterior com o distalizador Pendulum, necessita-se de uma maior cooperação do paciente do que no tratamento por meio das extrações de dois prémolares superiores. Isto porque é preciso promover a movimentação das raízes dos molares antes de mantê-los em posição durante a retração anterior, enquanto que no protocolo das extrações, somente se torna necessária a manutenção do posicionamento dos molares, não se constituindo em meta terapêutica a correção da relação molar. Conforme demonstrado teoricamente pelos estudos de ANDREWS $^{3}$ e clinicamente 
pelos trabalhos de BARROS $^{7}$, BRAMBILLA $^{14}$, JANSON et al. $^{52}$ e JANSON et al. ${ }^{51}$, o protocolo de tratamento da má oclusão de Classe ॥ com extrações de dois pré-molares superiores requer uma menor colaboração do paciente para a obtenção dos resultados oclusais satisfatórios, justificando assim o maior grau de efetividade deste tratamento. BARROS ${ }^{7}$ adverte que o tratamento da má oclusão de Classe II completa com extrações de dois pré-molares superiores difere do protocolo de tratamento sem extrações não apenas no tocante à realização ou não de extrações, mas sobretudo no que diz respeito à redução pela metade da necessidade de colaboração do paciente durante o tratamento.

SCUZZO; PISANI; TAKEMOTO ${ }^{97}$ descrevem que a obtenção do movimento de corpo dos molares durante a distalização é capaz de evitar um aumento no tempo de tratamento e, portanto, propuseram modificações no aparelho a fim de diminuir esta inclinação. Entretanto, não há trabalhos publicados comprovando a eficácia desta modificação.

Ao avaliar a fase de nivelamento após a utilização do aparelho Pendulum, ANGELIERI ${ }^{4}$, na mesma amostra utilizada para este estudo (exceto 1 paciente que foi eliminado na presente avaliação), verificou uma mesialização estatisticamente significante dos molares superiores de 1,2 mm em relação à fase final da distalização. Além da mesialização, os molares verticalizaram $7,63^{\circ}$. Durante o tratamento com o Pendulum, os molares foram distalizados com uma sobrecorreção de $2 \mathrm{~mm}$ pois, de acordo com HILGERS ${ }^{47}$, esta sobrecorreção é necessária visto que a 
distalização é obtida em grande parte pelo movimento de inclinação das coroas, esperando-se uma recidiva de aproximadamente 20 a 30\% durante a sua verticalização. Segundo ANGELIERI ${ }^{4}$, esta mesialização pode estar relacionada ao crescimento para anterior da maxila, à verticalização das raízes do primeiro molar superior e/ou ainda à recidiva devido à perda de ancoragem em função da característica altamente instável dos molares distalizados. Apesar da mesialização dos molares, ao final do nivelamento os pacientes ainda apresentavam uma relação molar normal.

Ao avaliar estes casos após o término do tratamento, ANGELIERI et al. ${ }^{5}$ observaram que os molares mesializaram $2,1 \mathrm{~mm}$, retornando ao posicionamento inicial. Como a relação molar e o trespasse horizontal finalizaram corrigidos, os autores atribuem esta correção principalmente às compensações dentárias e possivelmente a um crescimento mandibular.

A mesialização dos molares durante a terapia ortodôntica fixa que se segue à fase de distalização também foi observada por BURKHARDT; MCNAMARA JR; BACCETTII ${ }^{17}$. Os autores verificaram uma recidiva da distalização dos molares de $87 \%$ em relação à primeira fase do tratamento (uso do Pendulum), porém a relação molar normal foi mantida e o trespasse horizontal corrigido. De acordo com os autores, a manutenção da relação molar e da correção do trespasse horizontal, mesmo com a recidiva da distalização, pode ser explicada por um padrão de crescimento favorável e compensações dentoalveolares. 
Estas compensações dentoalveolares podem ser obtidas por meio da utilização dos elásticos intermaxilares de Classe II. Independentemente da mecânica utilizada, a quantidade de distalização do primeiro molar superior dificilmente é suficiente para a correção de toda a discrepância ântero-posterior ${ }^{7}$. Desta forma, alguma mesialização do molar inferior deve ocorrer a fim de possibilitar a correção da relação molar. Os elásticos intermaxilares de Classe II podem ser utilizados com este propósito, promovendo a movimentação dentária desde que haja grande cooperação na sua utilização por parte do paciente. Assim sendo, provavelmente a correção da relação molar foi influenciada pelas compensações dentoalveolares promovidas pelo uso dos elásticos de Classe II.

Além da necessidade da correção e manutenção da relação molar, o aumento do apinhamento, do trespasse horizontal e da inclinação dos incisivos $^{19,20,25,35,37,60}$ também podem ter colaborado para um aumento no tempo de tratamento. ANGELIERI ${ }^{4}$ descreve que em muitos pacientes, devido a um apinhamento anterior superior severo, acentuado pela perda de ancoragem ocorrida durante o tratamento com o Pendulum, foi necessário um maior tempo para o alinhamento e nivelamento dentário (em média 1 ano). Relata ainda que ocorrências clínicas como caninos superiores em inframesiovestibuloversão e a grande variação da severidade dos apinhamentos anteriores superiores levaram a uma diversidade do tempo decorrido para a finalização da fase de nivelamento. 
Como pôde ser observado na revisão de literatura, os primeiros trabalhos publicados sobre a utilização do aparelho Pendulum resumemse à descrição do aparelho ${ }^{2,33,73}$ e de casos clínicos ${ }^{13,69,113}$. A literatura pertinente ao estudo dos efeitos dentoalveolares e esqueléticos existe em um número relativamente pequeno ${ }^{4,5,19-21,35,37,102}$, sendo que a maioria dos estudos $^{19-21,35,37,102}$ avaliaram até a fase final da utilização do Pendulum, com apenas dois trabalhos ${ }^{5,17}$ que observaram o tratamento completo, incluindo a terapia ortodôntica pós-Pendulum.

O tempo de tratamento observado por BURKHARDT; McNAMARA JR; BACCETTI ${ }^{17}$ para os pacientes tratados com o Pendulum foi de 31,6 meses. Este tempo apresenta-se menor do que o obtido no presente estudo (45,7 meses - tabela 9). Esta situação provavelmente encontra-se relacionada à diferença entre as idades iniciais. A amostra avaliada por BURKHARDT; MCNAMARA JR; BACCETTI ${ }^{17}$ apresentou idade média inicial de 12,3 anos, enquanto que no presente estudo foi de 14,44 anos. Esta diferença entre as idades pode influenciar o tempo de tratamento uma vez que os resultados desejados são obtidos com maior facilidade para os grupos mais jovens, visto que o crescimento mandibular auxilia na correção da Classe $1{ }^{46}$.

Na literatura, há trabalhos que relatam um aumento no tempo de tratamento relacionado à realização de extrações dentárias $^{26,34,48,78,90,107,110}$. Entretanto, estudos demonstram que as más oclusões de Classe II tratadas com extrações apresentam um maior grau de discrepância ântero-posterior ${ }^{11,44,48,78,107}$. Sendo assim, a correção de 
uma má oclusão mais severa encontra-se relacionada a um maior tempo de tratamento ${ }^{44,90,107,110}$ e não necessariamente às extrações dentárias.

Torna-se necessário ressaltar que em vários dos estudos $48,90,107,110$ que associam o aumento do tempo de tratamento às realizações de extrações, os tipos de más oclusões não foram separados. Desta forma, os resultados obtidos poderão não ser extrapolados para um tipo isolado de má oclusão, uma vez que o protocolo de tratamento indicado para cada uma poderá instituir variáveis que lhe são peculiares, distorcendo os resultados obtidos ${ }^{7}$. Por exemplo, é de se esperar que a correção da Classe I sem extrações apresente um menor tempo de tratamento do que o da Classe II sem extrações uma vez que, para o tratamento desta, é necessária inicialmente a correção da relação molar ${ }^{7}$.

No presente estudo, o grupo com extrações de dois pré-molares apresentou um tempo significantemente menor de tratamento quando comparado ao tratado pelo Pendulum. Este resultado encontra-se de acordo com o obtido por BARROS ${ }^{7}$, que verificou em uma amostra homogênea em relação ao tipo e à severidade inicial da má oclusão que a realização de extrações de dois pré-molares superiores, por si só, não aumentou significantemente o tempo de tratamento, visto que esta variável apresentou-se significantemente maior no grupo tratado sem extrações.

Resultados semelhantes foram observados por MARIA $^{70}$ que encontrou melhores resultados oclusais em um tempo despendido de tratamento significantemente menor, no grupo tratado com extrações de 
dois pré-molares em relação ao tratado com quatro pré-molares. O mesmo autor ${ }^{71}$, ao comparar, anos mais tarde, o tempo de tratamento de um grupo tratado por meio de extrações de dois pré-molares superiores, à um grupo tratado inicialmente sem exodontias e depois replanejado, observou novamente um menor tempo de tratamento para o grupo planejado desde o início com as duas extrações ${ }^{71}$.

As variáveis capazes de influenciar o tempo de tratamento como faltas às consultas, quebras nos aparelhos, entre outras ${ }^{26,34,78,90,101}$ não foram consideradas no presente estudo, pois, assim como BARROS ${ }^{7}$, considerou-se que estas variáveis apresentam a mesma probabilidade de ocorrência entre os grupos por serem representativas não apenas do grau de colaboração, mas também das características psicossociais e comportamentais do paciente ${ }^{26,34,90}$. Além disto, a avaliação da colaboração não é o propósito deste estudo.

\subsubsection{A eficiência do tratamento ortodôntico}

A obtenção de bons resultados no tratamento ortodôntico encontrase relacionada à severidade inicial da má oclusão, ao correto diagnóstico e plano de tratamento por parte do profissional e à colaboração irrestrita do paciente, seguindo as recomendações prescritas ${ }^{109}$.

Nem sempre o tratamento ideal é o aceito pelo paciente. De acordo com URSI; ALMEIDA ${ }^{109}$ fatores como aceitação do paciente e seus pais, 
opinião de irmãos, colegas e amigos podem influenciar mais na colaboração do uso de um aparelho do que as recomendações do profissional.

O aparelho extrabucal e os elásticos intermaxilares dependem da colaboração do paciente ${ }^{109}$. A sua falta gera um aumento no tempo de tratamento, um desconforto na relação paciente/pais/profissional, aumenta o risco de iatrogenias e os resultados obtidos ficam aquém do ideal, resultando em insatisfação por parte do profissional ${ }^{109}$.

Cabe ao ortodontista realizar um tratamento dentro de um tempo razoável, utilizando aparelhos eficazes, melhorando a previsibilidade do tratamento e procurando limitar o uso dos aparelhos que necessitam de colaboração do paciente a períodos isolados e absolutamente necessários ${ }^{109}$. Impossibilitado de tornar o paciente mais cooperador, deve-se optar pelo tratamento menos dependente da sua colaboração ${ }^{109}$.

A obtenção dos melhores resultados possíveis em um menor tempo de tratamento ortodôntico constitui-se tanto no objetivo do profissional, como atende aos anseios do paciente. Assim quando mais de um protocolo de tratamento pode ser utilizado na correção de uma mesma má oclusão, deve-se optar por aquele que apresente comprovadamente uma maior eficiência ${ }^{7}$.

A aplicação de um índice de eficiência possibilita a avaliação e a comparação de maneira concreta e objetiva dos graus de eficiência dos dois protocolos investigados no presente estudo. 
O grau de eficiência foi avaliado a partir de um índice definido pela razão entre o porcentual de melhora e o tempo de tratamento em meses. O porcentual de melhora apresenta uma relação direta com o índice de eficiência, enquanto que o tempo de tratamento mantém uma relação inversa com este índice. Assim, o valor do índice de eficiência aumenta na medida em que porcentuais de melhora maiores se associam a tempos de tratamento menores.

No presente estudo, o grau de eficiência apresentou-se significantemente maior para o grupo tratado com as extrações de dois pré-molares quando comparado ao grupo tratado por meio do aparelho Pendulum (tabela 9). Possivelmente, esta diferença esteja relacionada principalmente ao tempo de tratamento, que se apresentou significantemente maior para o grupo tratado pelo distalizador intrabucal.

A incompatibilidade dos grupos quanto ao grau de severidade inicial poderia gerar críticas em relação aos resultados obtidos no presente estudo uma vez que WHEELER et al. ${ }^{112}$, ao avaliarem os resultados dos tratamentos sem extrações, demonstraram que a porcentagem de sucesso na correção da relação molar na má oclusão de Classe II encontra-se inversamente proporcional à severidade inicial dos casos, ou seja, a porcentagem de sucesso na correção do relacionamento ântero-posterior entre os molares apresentou-se maior quanto menor a severidade inicial dos casos. Este fato poderia influenciar os resultados, uma vez que o proposto foi a comparação entre os graus de eficiência, considerando-se os resultados oclusais e o tempo de tratamento. Este 
fator tenderia a favorecer o grupo tratado por meio do aparelho Pendulum, visto que neste grupo a severidade inicial apresentou-se menor (tabelas 5, 8 e 9), entretanto, observou-se, por meio dos resultados obtidos, que o grupo 2 (tratado por meio das extrações de dois pré-molares) apresentou um índice de eficiência significantemente maior do que o grupo 1 (tabela 9). Esta situação evidencia os resultados obtidos neste estudo, os quais, muito provavelmente, encontram-se relacionados à dificuldade da correção e manutenção do posicionamento ântero-posterior dos molares, com conseqüente aumento no tempo de tratamento no grupo tratado pelo distalizador.

No tratamento da má oclusão de Classe II completa com extrações de dois pré-molares superiores, torna-se necessário o uso de reforço de ancoragem para evitar a mesialização dos molares durante a retração dos dentes anteriores. Normalmente, os aparelhos que propiciam este reforço de ancoragem são os extrabucais e, portanto, requerem a colaboração dos pacientes para o sucesso do tratamento ${ }^{51}$. Nos casos onde se opta pelo tratamento sem extrações, a necessidade de reforço de ancoragem é ainda maior, pois os molares superiores devem não apenas ser mantidos no local, mas também distalizados para a obtenção de uma relação normal de molar e de canino. De acordo com GHOSH; NANDA ${ }^{37}$, uma das maiores dificuldades no tratamento da Classe II é a distalização dos molares para a obtenção de uma relação molar normal. $O$ aparelho Pendulum foi idealizado para promover esta distalização, sem a necessidade de cooperação do paciente, entretanto, observa-se uma 
inclinação axial para distal dos molares e perda de ancoragem na região anterior $^{5,17,19,20,25,37}$, necessitando-se, portanto, da utilização do aparelho extrabucal $^{5,19,37,38,40}$ para distalizar as raízes e manter os molares em posição durante a retração dos dentes anteriores. Desta forma, mesmo que a severidade inicial do grupo tratado pelo Pendulum apresente-se menor, a correção molar acabou por despender maior tempo de tratamento uma vez que o grau de eficiência é retratado pelo porcentual de melhora em relação ao tempo de tratamento (tabela 9).

\subsection{Avaliação dos índices oclusais}

Os valores do índice PAR ao final do tratamento foram desmembrados em seus diversos componentes (oclusão posterior, trespasse horizontal, trespasse vertical, apinhamento e linha média) para a aplicação da análise de regressão linear múltipla a fim de especificar quais as características oclusais que mais contribuíram para as alterações observadas. Os resultados demonstraram que todos os componentes avaliados influenciaram o valor deste índice ao final do tratamento, sendo que a oclusão posterior foi o que exerceu um maior peso (tabela 10 equação). Na comparação intergrupos de cada um dos componentes do índice PAR, realizada por meio do teste de Mann-Whitney, observou-se que os componentes tenderam a alcançar graus de correção semelhantes entre os grupos (tabela 11). Assim, os resultados oclusais entre os grupos 
foram semelhantes, mesmo quando avaliado isoladamente cada um dos componentes, entretanto, para obtê-los foi necessário um tempo de tratamento significantemente maior no grupo tratado pelo aparelho Pendulum (tabela 9).

Os índices IPT e PAR apresentam algumas diferenças em relação às características oclusais avaliadas. O índice PAR desconsidera $\mathrm{O}$ apinhamento ântero-inferior ${ }^{31}$, enquanto o IPT não avalia a linha média ${ }^{45}$. A relação ântero-posterior também apresenta diferenças entre os índices. No IPT acrescenta-se uma constante numérica à relação molar de Classe II, sendo que quanto maior a severidade da relação ântero-posterior existente entre os primeiros molares, maior o valor desta constante. No índice PAR, na região posterior avalia-se a relação cúspide/embrasura, desconsiderando-se a relação molar de Classe I, II ou III entre os arcos, verificando-se apenas a intercuspidação dentária. Como a obtenção da relação normal de caninos é o objetivo de todo o tratamento ortodôntico independentemente da relação ântero-posterior estabelecida na região posterior dos arcos, o maior peso previsto neste índice é aplicado ao trespasse horizontal ${ }^{31}$. Apesar das diferenças das características oclusais avaliadas, pode-se verificar, na tabela 12, o elevado coeficiente de correlação entre os índices oclusais IPT e PAR. Este resultado demonstra que ambos apresentam graus de sensibilidade semelhantes para identificar os desvios da oclusão em relação à normalidade e as alterações oclusais decorrentes do tratamento ortodôntico. 
Visto que o conjunto de características oclusais analisadas por um índice difere em certo grau do total de relações oclusais avaliadas pelo outro, a associação dos índices oclusais IPT e PAR permitiu avaliar com um grau de sensibilidade semelhante um maior número de características oclusais, aumentando a confiabilidade dos resultados.

\subsection{Implicações clínicas}

A opção de se extrair ou não dentes pode influenciar o resultado final, a demanda por uma maior ou menor colaboração durante a mecânica, assim como também a duração do tratamento ${ }^{7,90,110}$.

Apesar do conhecimento e da experiência clínica serem importantes, a cooperação do paciente tem um papel fundamental na obtenção dos resultados desejados.

Justificar a escolha do protocolo de tratamento a ser encetado baseado somente nos bons resultados obtidos nos trabalhos publicados não é suficiente ${ }^{110}$. É preciso considerar a eficiência do tratamento. Frente a duas opções de tratamento que promovam resultados satisfatórios, o tempo de tratamento pode ser o diferencial na opção selecionada.

Na correção da má oclusão de Classe II, a duração do tratamento e a qualidade dos resultados obtidos estão relacionados à colaboração do paciente na utilização de dispositivos para auxiliarem a distalização ou mesmo para manterem os dentes posteriores na posição original durante 
a retração dos dentes anteriores. Apesar da colaboração ser necessária nos dois protocolos avaliados no presente estudo, ela precisa ser maior no grupo tratado pelo aparelho Pendulum uma vez que este dispositivo promove a distalização dos molares principalmente por inclinação destes dentes. Enquanto que no grupo tratado pelas extrações dos primeiros prémolares superiores, a colaboração estava relacionada ao uso do aparelho extrabucal apenas com a finalidade de manter os molares superiores na sua posição original, o que possibilita a utilização por um menor período de tempo, favorecendo o seu uso.

A manutenção dos molares superiores na posição original nos casos tratados com extrações apenas superiores ${ }^{15,51,52}$ facilita a mecânica, necessitando-se de menor colaboração do paciente. De acordo com JANSON et al. $^{52}$, JANSON et al. $^{51}$, ROOB et al. ${ }^{90}$, TURBILL; RICHMOND; WRIGHT ${ }^{107}$ e VIG et al. ${ }^{110}$ a correção da relação molar dificulta e prolonga o tratamento ortodôntico da má oclusão de Classe II.

Apesar da utilização do aparelho Pendulum prolongar o tempo de tratamento, obteve-se, ao final do tratamento, bons resultados oclusais. Assim, dependendo da severidade da discrepância ântero-posterior, da idade do paciente e também da resistência dos pais ou do próprio paciente às extrações, o aparelho Pendulum pode ser indicado, desde que o paciente e/ou os responsáveis estejam cientes da opção por um tratamento mais prolongado.

Uma vez que os resultados oclusais obtidos ao final do tratamento apresentaram-se semelhantes entre os grupos, enquanto que o tempo de 
tratamento apresentou-se significantemente aumentado no grupo tratado pelo Pendulum, a opção pelo protocolo de tratamento deve basear-se no grau de eficiência de cada uma das opções de correção acima avaliadas.

\subsection{Sugestões para novos trabalhos}

- Comparação das alterações cefalométricas e do perfil facial entre os dois grupos.

- Verificação da influência da colaboração nos resultados obtidos.

- Comparação entre os grupos da estabilidade da correção.

- Avaliação da distalização com a utilização de implantes. 
7 Conclusões 


\section{7 cONCLUSÕES}

De acordo com a metodologia aplicada e após a análise criteriosa dos resultados, parece lícito concluir que:

7.1- a hipótese nula de que não há diferença entre os graus de eficiência do tratamento da má oclusão de Classe II realizado com o aparelho Pendulum e com extrações de dois prémolares superiores foi rejeitada, uma vez que o índice de eficiência do tratamento apresentou-se significantemente maior para o grupo tratado com as extrações dos pré-molares superiores;

7.1.1- os dois protocolos avaliados apresentaram-se eficazes na correção da má oclusão de Classe II;

7.1.2- verificou-se um menor tempo de tratamento para a correção da Classe II por meio do protocolo de extrações de dois prémolares superiores. 
Referências Bibliográficas 


\section{REFERÊNCIAS BIBLIOGRÁFICAS ${ }^{4}$}

1. AleXANDER, R. G.; SINCLAIR, P. M.; GOATES, L. J. Differential diagnosis and treatment planning for the adult nonsurgical orthodontic patient. Am J Orthod, v.89, n.2, p.95-112, Feb. 1986.

2. AlMEIDA, R. R. et al. Modificação do aparelho Pendulum/Pend-X. Descrição do aparelho e técnica de construção. Rev Dent Press Ortod Ortop Facial, v.4, n.6, p.12-9, nov./dez. 1999.

3. ANDREWS, L. F. The straight wire appliance. Syllabus of philosophy and techniques. 2 ed., 1975.

4. ANGELIERI, F. Avaliação cefalométrica pós-distalização realizada por meio do aparelho Pendulum, em pacientes em tratamento ortodôntico com aparelho fixo Bauru, 2002. 171p. Dissertação (Mestrado) - Faculdade de Odontologia de Bauru, Universidade de São Paulo.

5. ANGELIERI, F. et al. Dentoalveolar and skeletal changes associated with the Pendulum appliance followed by fixed orthodontic treatment. Am J Orthod Dentofacial Orthop, No prelo, aceito em 2004.

6. BACCETTI, T. Early dentofacial features of Class II malocclusion: a longitudinal study from deciduous through the mixed dentition. Am J Orthod Dentofacial Ortho., v.111, n.5, p.502-9, May 1997.

7. BARROS, S. E. C. Avaliação do grau de eficiência do tratamento da Classe II realizado sem extrações e com extrações de dois

\footnotetext{
${ }^{4}$ Normas recomendadas para uso no âmbito da Universidade de São Paulo, com base no documento "Referências Bibliográficas: exemplos", emanado do Conselho Supervisor do Sistema Integrado de Bibliotecas da USP, em reunião de 20 de setembro de 1990.
} 
pré-molares superiores Bauru, 2004. 152p. Dissertação (Mestrado) - Faculdade de Odontologia de Bauru, Universidade de São Paulo.

8. BAUMRIND, S. et al. The decision to extract: Part II. Analysis of clinicians' stated reasons for extraction. Am J Orthod Dentofacial Orthop, v.109, n.4, p.393-402, Apr. 1996.

9. BIRKELAND, K. et al. Evaluation of treatment and post-treatment changes by the PAR Index. Eur J Orthod, v.19, n.3, p.279-88, June 1997.

10.BISHARA, S. E.; CUMMINS, D. M.; JAKOBSEN, J. R. The morphologic basis for the extraction decision in Class II, division 1 malocclusions: a comparative study. Am J Orthod Dentofacial Orthop, v.107, n.2, p.129-35, Feb. 1995.

11. BISHARA, S. E. et al. Dentofacial and soft tissue changes in Class II, division 1 cases treated with and without extractions. Am J Orthod Dentofacial Orthop, v.107, n.1, p.28-37, Jan. 1995.

12. BISHARA, S. E.; PETERSON, L. C.; BISHARA, E. C. Changes in facial dimensions and relashionships between the ages of 5 and 25 years. Am J Orthod, v.85, n.3, p.238-52, Mar. 1984.

13. BORTOLOZO, M. A. et al. Distalização de molares superiores com o Pendulum/Pendex: o aparelho, seu modo de ação, possibilidades e limitações. R Dental Press Ortodon Ortop Facial, v.6, n.4, p.4350, jul./ago. 2001.

14. BRAMBILLA, A. D. Comparação dos resultados oclusais do tratamento da Classe II realizado com extrações de dois pré- 
molares, com a terapêutica utilizando as extrações de quatro pré-molares Bauru, 2002. 92p. Dissetração (Mestrado) Faculdade de Odontologia de Bauru, Universidade de São Paulo.

15.BRYK, C.; WHITE, L. W. The geometry of Class II correction with extractions. J Clin Orthod, v.35, n.9, p.570-9, Sep. 2001.

16. BUCHANAN, I. B. et al. A comparison of the reliability and validity of the PAR index and Summer's occlusal index. Eur J Orthod, v.15, n.1, p.27-31, Feb. 1993.

17. BURKHARDT, D. R.; McNAMARA JR, J. A.; BACCETI, T. Maxillary molar distalization or mandibular enhancement: a cephalometric comparison of comprehensive orthodontic treatment including the pendulum and the Herbst appliances. Am J Orthod Dentofacial Orthop, v.123, n.2, p.108-16, Feb. 2003.

18. BURSTONE, C. J. Beta titanium: a new orthodontic alloy. Am J Orthod, v.77, n.2, p.121-32, Feb. 1980.

19.BUSSICK, T. J.; MCNAMARA JR, J. A. Dentoalveolar and skeletal changes associated with the pendulum appliance. Am J Orthod Dentofacial Orthop, v.117, n.3, p.333-43, Mar. 2000.

20. BYLOFF, F. K.; DARENDELILER, M. A. Distal molar movement using the pendulum appliance. Part 1: clinical and radiological evaluation. Angle Orthod, v.67, n.4, p.249-60, Apr. 1997.

21. BYLOFF, F. K. et al. Distal molar movement using the pendulum appliance. Part 2: The effects of maxillary molar root uprighting bends. Angle Orthod, v.67, n.4, p.261-70, Apr. 1997. 
22. CARANO, A.; TESTA, M. The distal jet for upper molar distalization. $\mathbf{J}$ Clin Orthod, v.30, n.7, p.374-90, July 1996.

23. CARTER, N. E. Dentofacial changes in untreated Class II division 1 subjects. Brit J Orthod, v.14, n.4, p.225-34, Nov. 1987.

24. CASE, C. S. The question of extraction in orthodontia. Am J Orthod, v.50, n.9, p.660-91, Sep. 1964.

25. CHAQUÉS-ASENSI, J.; KALRA, V. Effects of the pendulum appliance on the dentofacial complex. J Clin Orthod, v. 35, n.4, p. 254-7, Apr. 2001.

26. CHEW, M. T.; SANDHAM, A. Effectiveness and duration of two-arch fixed appliance treatment. Aust Orthod J, v.16, n.2, p.98-103, July 2000.

27. CUCALON, A.; SMITH, R. J. Relationship between compliance by adolescent orthodontic patients and performance on psychological tests. Angle Orthod, v.60, n.2, p.107-14, Summer 1990.

28. DAHLBERG, G. Statistical methods for medical and biological students. New York, Intercience, 1940.

29.DANN, C. et al. Self-concept, Class II malocclusion, and early treatment. Angle Orthod, v.65, n.6, p.411-6, Dec. 1995.

30. DeANGELIS, V. Selection of teeth for extraction as an adjunct to orthodontic treatment. J Am Dent Assoc, v.87, n.3, p.610-5, Sep. 1973. 
31. DeGUZMAN, L. et al. The validation of the Peer Assessment Rating index for malocclusion severity and treatment difficulty. Am J Orthod Dentofacial Orthop, v.107, n.2, p.172-6, Feb. 1995.

32. DRELICH, R. C. A cephalometric study of untreated Class II, division 1 malocclusion. Angle Orthod, v.18, n.3-4, p.70-5, July/Oct. 1948.

33. FIGUEIREDO, C. T. P.; FIGUEIREDO, M. A.; NOBUYASU, $M$. Distalização de molares superiores com 0 aparelho Pendulum/Pendex. Rev Ass Paul Cir Dent, v.53, n.1, p.27-30, jan./fev. 1999.

34. FINK, D. F.; SMITH, R. J. The duration of orthodontic treatment. Am J Orthod Dentofacial Orthop, v.102, n.1, p.41-51, July 1992.

35. FUZIY, A. Estudo das alterações sagitais, verticais e transversais decorrentes da distalização dos molares superiores com o aparelho Pendulum. Bauru, 2001. 255p. Tese (Doutorado) Faculdade de Odontologia de Bauru - Universidade de São Paulo.

36. GHAFARI, J.; LOCKE, S. A.; BENTLEY, J. M. Longitudinal evaluation of the Treatment Priority Index (TPI). Am J Orthod Dentofacial Orthop, v.96, n.5, p.382-9, Nov. 1989.

37. GHOSH, J.; NANDA, R. S. Evaluation of an intraoral maxillary molar distalization technique. Am J Orthod Dentofacial Orthop, v.110, n.6, p. 639-46, Dec. 1996.

38. GIANCOTTI, A. Nonextraction treatment of a high-angle Class II malocclusion: a case report. Am J Orthod Dentofacial Orthop, v.117, n.6, p.721-7, June 2000. 
39. GIANELLY, A. A. Distal movement of the maxillary molars. Am $\mathbf{J}$ Orthod Dentofacial Orthop, v.114, n.1, p.66-72, July 1998.

40. GIANELLY, A. A.; BEDNAR, J.; DIETZ, V. S. Japaneses Ni-Ti coils used to move molars distally. Am J Orthod Dentofacial Orthop, v.99, n.6, p.564-66, June 1991.

41. GRABER, T. M. Current orthodontic concepts and techniques. Philadelphia, W.B. Saunders Company, 1969.

42. GRABER, T. M. Maxillary second molar extraction in Class II malocclusion. Am J Orthod, v.56, n.4, p.331-53, Oct. 1969.

43. GRABER, T. M.; VANARSDALL, R. L. Orthodontics: current principles and techniques. 2 ed. St. Lowis, Mosby, 1994.

44. GRACIANO, J. T. A. Características oclusais e cefalométricas de pacientes com Classe II, divisão 1, tratados com e sem extrações de dois pré-molares superiores Bauru, 2003. 161p. Dissertação (Mestrado) - Faculdade de Odontologia de Bauru, Universidade de São Paulo.

45. GRAINGER, R. M. Orthodontic Treatment Priority Index. Washington D.C., National Center for Health Statistics, Education and Welfare, 1967.

46. HARRIS, E. F.; DYER, G. S.; VADEN, J. L. Age effects on orthodontic treatment: skeletodental assessments from Johnston analysis. Am J Orthod Dentofacial Orthop, v.100, n.6, p.531-6, Dec. 1991.

47. HILGERS, J. J. The Pendulum appliance for class II non-compliance therapy. J Clin Orthod, v. 26, n.11, p. 706-14, Nov. 1992. 
48. HOLMAN, J. K. et al. A assessment of extraction versus nonextraction orthodontic treatment using the peer assessment rating (PAR) index. Angle Orthod, v.68, n.6, p.527-34, Dec. 1998.

49. HOUSTON, W. J. B. Analysis of errors in orthodontics measurements. Am J Orthod, v.83, n.5, p.382-90, May 1983.

50. JACOBSON, A. The "Wits" appraisal of jaw disharmony. Am J Orthod, v.64, n.2, p.125-38, Feb. 1975.

51. JANSON, G. et al. Class II treatment success rate in 2 and 4 premolar extraction protocols. Am J Orthod Dentofacial Orthop, v.125, n.4, p.472-9, Apr. 2004.

52. JANSON, G. et al. Class II subdivision treatment success rate with symmetric and asymmetric extraction protocols. Am J Orthod Dentofacial Orthop, v.124, n.3, p.257-64, Sep. 2003.

53. JANSON, M. R. P. Influência das características cefalométricas na proporção de sucesso do tratamento da Class II com extrações de dois e de quatro pré-molares Bauru, 2004. 166p. Dissertação (Mestrado) - Faculdade de Odontologia de Bauru, Universidade de São Paulo.

54.JONES, R. D.; WHITE, J. M. Rapid Class II molar correction with an open-coil jig. J Clin Orthod, v.26, n.2, p.661-4, Oct. 1992.

55. KARLSEN, A. T. Craniofacial morphology in children with Angle Class II-1 malocclusion with and without deepbite. Angle Orthod, v.64, n.6, p.437-46, June 1994. 
56. KARLSEN, A. T.; KROGSTAD, O. Morphology and growth in convex profile facial patterns: a longitudinal study. Angle Orthod, v.69, n.4, p.334-44, Apr. 1999.

57. KERR, W. J.; HIRST, D. Craniofacial characteristics of subjects with normal and postnormal occlusions - a longitudinal study. Am J Orthod Dentofacial Orthop, v.92, n.3, p.207-12, Sep. 1987.

58. KESSEL, S. P. The rationale of maxillary premolar extraction only in Class II therapy. Am J Orthod, v.49, n.4, p.276-93, Apr. 1963.

59. KINZINGER, G. S. M. et al. Efficiency of a pendulum appliance for molar distalization related to second and third molar eruption stage. Am J Orthod Dentofacial Orthop, v.125, n.1, p.8-23, Jan. 2004.

60. KINZINGER, G. S. M. et al. Modified Pendulum appliance including distal screw and uprighting activation for non-compliance therapy of Class II malocclusion in children and adolescents. J Orofac Orthop, v.61, n.3, p.175-90, 2000.

61. KLAPPER, L. et al. The influence of extraction and nonextraction orthodontic treatment on brachyfacial and dolichofacial growth patterns. Am J Orthod Dentofacial Orthop, v.101, n.5, p.425-30, May 1992.

62. KLOEHN, S. Orthodontics - force or persuasion. Angle Orthod, v.23, n.1, p.56-66, Jan. 1953.

63. KLOEHN, S. J. Evaluation of cervical anchorage force in treatment. Angle Orthod, v.31, n.2, p.91-104, Feb. 1961. 
64. KROGMAN, W. M.; SASSOUNI, V. A syllabus in roentgenographic cephalometry. Philadelfia, Philadelphia Center for Research in Child Growth, 1957.

65. LEGAN, H. L.; BURSTONE, C. J. Soft tissue cephalometric analysis for orthognatic surgery. J Oral Surg, v.38, n.10, p.744-51, Oct. 1980.

66. LEWIS, E. A. et al. Reliability and validity of clinical assessments of malocclusion. Am J Orthod, v.81, n.6, p.473-7, June 1982.

67. LINKLATER, R.; FOX, N. The long-term benefits of orthodontic treatment. Br Dent J, v.192, n.10, p.583-7, May 2002.

68. LUECKE III, P. E.; JOHNSTON, L. E. The effect of maxillary first premolar extraction and incisor retraction on mandibular position: testing the central dogma of "functional orthodontics". Am J Orthod Dentofacial Orthop, v.101, n.1, p.4-12, Jan. 1992.

69. MACEDO, D. M.; AIDAR, L. A. A. Uso do Pêndulo de Hilgers: apresentação de um caso clínico. Rev Dent Press Ortod Ortop, v.6, n.1, p.63-71, jan./fev. 2001.

70. MARIA, F. R. T. Estudo do tempo de tratamento de casos tratados ortodonticamente com extrações de dois pré-molares superiores comparados aos de extrações de quatro prémolares. Bauru, 2003. 111p. Dissertação (Mestrado) - Faculdade de Odontologia de Bauru - Universidade de São Paulo.

71. MARIA, F. R. T. et al. Influência da cooperação no planejamento e tempo de tratamento da má oclusão de Classe II. R Dental Press Ortodon Ortop Facial, v.10, n.2, p.44-53, mar./abr. 2005. 
72. MARTINS, D. R. et al. Atlas de crescimento craniofacial. Bauru, Ed. Santos, 1998.

73. MARTINS, J. C. R.; MELO, A. C. M.; MARTINS, L. P. "Pendex" modificado: um novo aparelho para distalização dos molares superiores no tratamento da má oclusão de Classe II. J Bras Ortod, v.1, n.4, p.37-43, jul./ago. 1996.

74. McNAMARA JR, J. A. Components of Class II malocclusion in children 8-10 years of age. Angle Orthod, v.51, n.3, p.177-202, July 1981.

75. McNAMARA JR, J. A. A method of cephalometric evaluation. Am J Orthod, v.86, n.6, p.449-69, Dec. 1984.

76. MOYERS, R. E. Handbook of orthodontics. 4 ed. Chicago, Mosby Year Book Medical Publishers, 1988.

77. NANGIA, A.; DARENDELILER, M. A. Finishing occlusion in Class II or Class III molar relation: therapeutic Class II and III. Aust Orthod J, v.17, n.2, p.89-94, Nov. 2001.

78. O'BRIEN, K. D. et al. The effectiveness of Class II, division 1 treatment. Am J Orthod Dentofacial Orthop, v.107, n.3, p.32934, Mar. 1995.

79. PETRONE, J. et al. Relationship of malocclusion severity and treatment fee to consumer's expectation of treatment outcome. Am J Orthod Dentofacial Orthop, v.124, n.1, p.41-5, July 2003.

80. PROFFIT, W. R. Orthodontic treatment planning: limitations and special problems. In: Contemporary orthodontics. 2 ed. St Louis: Mosby 1993. Cap. 8, p.225-64. 
81. PROFFIT, W. R. et al. Surgical versus orthodontic correction of skeletal Class II malocclusion in adolescents: effects and indications. Int J Adult Orthodon Orthognath Surg, v.7, n.4, p.209-20, Apr. 1992.

82. PROFFIT, W. R.; TULLOCH, C. Preadolescent Class II problems: treat now or wait? Am J Orthod Dentofacial Orthop, v.121, n.6, p.5602, June 2002.

83. RIBAREVSKI, R. et al. Consistency of orthodontic extraction decisions. Eur J Orthod, v.18, n.1, p.77-80, Feb. 1996.

84. RICHMOND, S. Personal audit in orthodontics. Br Dent J, v.20, n.2, p.135-44, May 1993.

85. RICHMOND, S. et al. The development of the PAR index (Peer Assessment Rating): reliability and validity. Eur J Orthod, v.14, n.2, p.125-39, Apr.1992.

86. RICHMOND, S. et al. The PAR (Peer Assessment Rating): methods to determine outcome of orthodontic in terms of improvement and standards. Eur J Orthod, v.14, n.3, p.180-7, June 1992.

87. RICKETTS, R. M. A four-step method to distinguish orthodontic from natural growth. J Clin Orthod, v.9, n.4, p.208-28, Apr. 1975.

88. RIOLO, M. L. et al. An atlas of craniofacial growth: cephalometric standards from the university school growth study. Ann Arbor, Center for human growth and development - University of Michigan, 1974. 
89. RONDEAU, B. H. M. The pendulum appliance. J Gen Orthod, v.6, n.1, p.22-30, Mar. 1995.

90.ROOB, S. I.; SADOWSKY, C.; SCHNEIDER, B. J. Effectiveness and duration of orthodontic treatment in adults and adolescents. Am J Orthod Dentofacial Orthop, v.114, n.4, p.383-6, Oct. 1998.

91. ROSEMBLUM, R. E. Class II malocclusion: mandibular retrusion or maxillary protrusion? Angle Orthod, v.65, n.1, p.49-62, Jan. 1995.

92. ROTHSTEIN, T. L. Facial morphology and growth from 10 to 14 years of age in children presenting Class II, division 1 malocclusion: a comparative roentgenographic cephalometric study. Am J Orthod, v.60, n.6, p.619-20, Dec. 1971.

93. ROTHSTEIN, T. L.; YOON-TARLIE, C. Dental and facial skeletal characteristics and growth of males and females with Class II, division 1 malocclusion between the ages of 10 and 14 (revisited) Part 1: characteristics of size, form and position. Am J Orthod Dentofacial Orthop, v.117, n.3, p.320-32, Mar. 2000.

94. RUSSELL, D. M. Extractions in support of orthodontic treatment. NDA Journal, v.45, n.2, p.15-9, June/July 1994.

95. SALZMANN, J. A. A practice of orthodontics. 2 ed. Philadelphia: J. B. Lipincott Company, 1966.

96. SCHUTZ-FRANSSON, V.; BJERKLIN, K.; KURD, J. Mandibular incisor stability after bimaxillary orthodontic treatment with premolar extraction in the upper arch. J Orofac Orthop, v.59, n.1, p.47-58, 1998. 
97. SCUZZO, G.; PISANI, F.; TAKEMOTO, K. Maxillary molar distalization with a modified Pendulum appliance. J Clin Orthod, v.33, n.11, p.645-50, Nov. 1999.

98. SCUZZO, G. et al. The modified Pendulum appliance with removable arms. J Clin Orthod, v.34, n.4, p.244-6, Apr. 2000.

99. SHAW, W. C. et al. Quality control in orthodontics: indices of treatment need an treatment standards. Br Dent J, v.170, n.3, p.107-12, Feb. 1991.

100. SHAW, W. C.; RICHMOND, S.; O'BRIEN, K. D. The use of occlusal indices: a european perspective. Am J Orthod Dentofacial Orthop, v.107, n.1, p.1-10, Jan. 1995.

101. SHIA, G. J. Treatment overruns. J Clin Orthod, v.20, n.9, p.602-4, Sep. 1986.

102. SNODGRASS, D. J. A fixed appliance for maxillary expansion, molar rotation and molar distalization. J Clin Orthod, v.30, n.3, p.1569, Mar. 1996.

103. STARNBACH, H. K.; KAPLAN, A. Profile of an excellent orthodontic patient. Angle Orthod, v.45, n.2, p.141-5, Apr. 1975.

104. STEINER, C. C. Cephalometrics as a clinical tool. In: KRAUS B. S., RIEDEL R. A. Vistas in orthodontics. Philadelphia: Lea \& Febiger; 1962. p.131-61.

105. TANER, T. U. et al. A comparative analysis of maxillary tooth movement produced by cervical headgear and pend-x appliance. Angle Orthod, v.73, n.6, p. 686-91, Dec. 2003. 
106. TUNG, A. W.; KIYAK, H. A. Psychological influences on the timing of orthodontic treatment. Am J Orthod Dentofacial Orthop, v.113, n.1, p.29-39, Jan. 1998.

107. TURBILL, E. A.; RICHMOND, S.; WRIGHT, J. L. The time-factor in orthodontics: what influences the duration of treatments in national health service practices? Community Dent Oral Epidemiol, v.29, n.1, p.62-72, Feb. 2001.

108. TWEED, C. H. The application of the principles of the Edgewise arch in the treatment of Class II, division 1 malocclusion: part 2. Angle Orthod, v.11, n.1, p.12-67, Jan. 1941.

109. URSI, W. J. S.; ALMEIDA, G. A. Cooperação mínima utilizando o Pêndulum de Hilgers. R Dental Press Ortodon Ortop Facial, v.7, n.2, p.87-123, mar./abr. 2002.

110. VIG, P. S. et al. The duration of orthodontic treatment with and without extractions: a pilot study of five selectes practices. Am J Orthod Dentofacial Orthop, v.97, n.1, p.45-51, Jan. 1990.

111. WEST, K. S.; McNAMARA JR, J. A. Changes in the craniofacial complex from adolescence to midadulthood: a cephalometric study. Am J Orthod Dentofacial Orthop, v.115, n.5, p.521-32, May 1999.

112. WHELLER, T. et al. Effectiveness of early treatment of Class II malocclusion. Am J Orthod Dentofacial Orthop, v.121, n.1, p.917, Jan. 2002. 
113. WONG, A. M. K.; RABIE, A. B. M.; HÄGG, U. The use of Pendulum appliance in the treatment of Class II malocclusion. Br Dent $\mathbf{J}$, v.187, n.7, p.367-70, Oct. 1999. 
Abstract 


\section{ABSTRACT}

The purpose of this study was to compare the efficiency of Class II treatment with the Pendulum appliance and with extraction of two maxillary premolars. For this, 48 treated Class II malocclusion patients were selected and divided into two groups according to the treatment protocol: group 1 consisted of dental study models and initial cephalograms of 22 patients treated with the Pendulum appliance, with an initial mean age of 14,44 years and group 2, consisted of dental study models and initial cephalograms of 26 patients treated with two maxillary premolar extractions and a initial mean age of 13,66 years. To compare the efficiency of each treatment protocol, the occlusal outcomes were evaluated on dental casts with the TPI and the PAR occlusal indexes and the treatment time of each group was calculated on the clinical charts. The treatment efficiency degree was calculated as the ratio between the percentages of occlusal improvement, evaluated through the TPI or PAR, by the treatment time. The occlusal indexes, the treatment time and the treatment protocols efficiency degree of the groups were compared by means of the $t$ test. Results demonstrated that the two maxillary premolar extraction protocol provided the occlusal outcomes in a shorter treatment time and, therefore, a greater treatment efficiency than the Pendulum treatment. 
Apêndice 


\section{APÊNDICE}

As tabelas A-1 e A-2 referem-se às características iniciais do paciente, assim como os tempos de tratamento. Nas tabelas A-3 e A-4 encontram-se os valores para o índice IPT, enquanto que nas tabelas A-5 e A-6, para o índice PAR. Da tabela A-7 à A-18 pode-se verificar os valores iniciais das grandezas cefalométricas avaliadas. Os pacientes que compõem o erro do método e as respectivas medidas do primeiro e segundo traçados e da primeira e segunda medições nos modelos de gesso encontram-se dispostas nas tabelas A-19 à A-26. 
TABELA A - 1

\begin{tabular}{|c|c|c|c|c|c|c|c|}
\hline Paciente & Grupo & Gênero & $\begin{array}{l}\text { Tipo de } \\
\text { Classe II }\end{array}$ & Relação molar & Idade I & $\begin{array}{c}\text { Ttrat } \\
\text { (meses) }\end{array}$ & $\begin{array}{r}\text { Ttrat } \\
\text { (anos) }\end{array}$ \\
\hline 1. A.O. & 1 & $\mathrm{~F}$ & 1 & $1 / 2$ Classe II & 13,54 & 39,32 & 3,28 \\
\hline 2. A.L.B. & 1 & $\mathrm{~F}$ & 1 & 1/4 Classe II & 15,21 & 73,68 & 6,14 \\
\hline 3. A.G. & 1 & $\mathrm{~F}$ & 1 & 1/4 Classe II & 15,53 & 45,44 & 3,79 \\
\hline 4. B.H.B. & 1 & $\mathrm{~F}$ & 1 & 3/4 Classe II & 14,69 & 54,71 & 4,56 \\
\hline 5. B.D.F. & 1 & $\mathrm{M}$ & 1 & 1/2 Classe II & 12,02 & 37,51 & 3,13 \\
\hline 6. C.T.P.D. & 1 & $\mathrm{~F}$ & 1 & Classe II completa & 17,52 & 24,95 & 2,08 \\
\hline 7. C.P.G. & 1 & $\mathrm{~F}$ & 1 & 3/4 Classe II & 17,65 & 31,86 & 2,65 \\
\hline 8. C.R. & 1 & $\mathrm{M}$ & 1 & 3/4 Classe II & 15,05 & 45,17 & 3,76 \\
\hline 9. F.N.O. & 1 & $\mathrm{M}$ & 2 & 3/4 Classe II & 17,62 & 34,13 & 2,84 \\
\hline 10. F.P.G. & 1 & $\mathrm{M}$ & 1 & 3/4 Classe II & 15,28 & 55,73 & 4,64 \\
\hline 11. H.A.C.P. & 1 & $\mathrm{M}$ & 1 & 1/4 Classe II & 12,38 & 30,90 & 2,58 \\
\hline 12. H.M.C. & 1 & $\mathrm{M}$ & 1 & 3/4 Classe II & 11,60 & 52,54 & 4,38 \\
\hline 13. L.P. & 1 & $\mathrm{~F}$ & 1 & 1/2 Classe II & 14,79 & 36,89 & 3,07 \\
\hline 14. L.Z.I. & 1 & $\mathrm{~F}$ & 1 & 1/2 Classe II & 14,15 & 37,18 & 3,10 \\
\hline 15. M.B.V. & 1 & $\mathrm{~F}$ & 1 & Classe II completa & 13,70 & 57,11 & 4,76 \\
\hline 16. N.M.N.O. & 1 & $\mathrm{~F}$ & 1 & $1 / 2$ Classe II & 12,60 & 36,00 & 3,00 \\
\hline 17. R.C.O. & 1 & $\mathrm{~F}$ & 1 & Classe II completa & 13,74 & 56,94 & 4,75 \\
\hline 18. R.Z.I. & 1 & $\mathrm{~F}$ & 1 & 1/4 Classe II & 11,81 & 43,43 & 3,62 \\
\hline 19. R.S.L. & 1 & $\mathrm{~F}$ & 1 & Classe II completa & 12,62 & 64,80 & 5,40 \\
\hline 20. S.B.H. & 1 & $\mathrm{~F}$ & 1 & Classe II completa & 13,99 & 55,86 & 4,65 \\
\hline 21. T.G.Q. & 1 & $\mathrm{~F}$ & 2 & 1/2 Classe II & 16,13 & 40,73 & 3,39 \\
\hline 22. V.B. & 1 & $\mathrm{M}$ & 2 & Classe II completa & 16,15 & 50,56 & 4,21 \\
\hline 23. A.M.G. & 2 & $\mathrm{M}$ & 1 & Classe II completa & 13,00 & 13,84 & 1,15 \\
\hline 24. A.M. & 2 & $\mathrm{M}$ & 1 & Classe II completa & 14,33 & 21,73 & 1,81 \\
\hline 25. A.G.B & 2 & $\mathrm{M}$ & 1 & Classe II completa & 14,67 & 26,66 & 2,22 \\
\hline 26. E.K. & 2 & $\mathrm{M}$ & 2 & Classe II completa & 13,75 & 18,64 & 1,55 \\
\hline 27. E.S.P. & 2 & $M$ & 2 & Classe II completa & 15,08 & 22,06 & 1,84 \\
\hline 28. E.A.M. & 2 & $\mathrm{M}$ & 1 & Classe II completa & 14,67 & 24,85 & 2,07 \\
\hline 29. E.C.D. & 2 & $\mathrm{~F}$ & 1 & Classe II completa & 14,33 & 18,64 & 1,55 \\
\hline 30. H.A.J.S. & 2 & $\mathrm{M}$ & 1 & Classe II completa & 12,67 & 21,63 & 1,80 \\
\hline 31. H.S.S. & 2 & $\mathrm{~F}$ & 1 & Classe II completa & 12,42 & 15,58 & 1,30 \\
\hline 32. I.A.F.M. & 2 & $\mathrm{M}$ & 2 & Classe II completa & 14,67 & 11,01 & 0,92 \\
\hline 33. J.O. & 2 & $\mathrm{~F}$ & 1 & Classe II completa & 15,08 & 37,51 & 3,13 \\
\hline 34. L.F.D. & 2 & $\mathrm{M}$ & 1 & Classe II completa & 13,33 & 23,70 & 1,98 \\
\hline 35. L.J.P.P. & 2 & $\mathrm{M}$ & 1 & Classe II completa & 13,50 & 24,85 & 2,07 \\
\hline 36. L.C.M. & 2 & $\mathrm{~F}$ & 1 & Classe II completa & 14,00 & 23,44 & 1,95 \\
\hline 37. L.A.B.P. & 2 & $\mathrm{~F}$ & 1 & Classe II completa & 14,00 & 18,15 & 1,51 \\
\hline 38. L.G.C.R. & 2 & $\mathrm{M}$ & 1 & Classe II completa & 12,83 & 21,53 & 1,79 \\
\hline 39. M.C.M.B. & 2 & $\mathrm{~F}$ & 1 & Classe II completa & 15,00 & 32,12 & 2,68 \\
\hline
\end{tabular}


TABELA A - 2

\begin{tabular}{|l|c|c|c|c|c|c|c|}
\hline \hline \multicolumn{1}{|c|}{ Paciente } & Grupo & Gênero & $\begin{array}{c}\text { Tipo de } \\
\text { Classe II }\end{array}$ & Relação molar & Idade I & $\begin{array}{c}\text { Ttrat } \\
\text { (meses) }\end{array}$ & $\begin{array}{c}\text { Ttrat } \\
\text { (anos) }\end{array}$ \\
\hline \hline 40. M.F.Z.C. & 2 & $\mathrm{~F}$ & 1 & Classe II completa & 12,00 & 20,55 & 1,71 \\
\hline 41. P.G.O. & 2 & $\mathrm{~F}$ & 1 & Classe II completa & 12,92 & 19,36 & 1,61 \\
\hline 42. R.C.C. & 2 & $\mathrm{~F}$ & 1 & Classe II completa & 14,00 & 23,15 & 1,93 \\
\hline 43. R.F. & 2 & $\mathrm{~F}$ & 1 & Classe II completa & 13,08 & 21,99 & 1,83 \\
\hline 44. S.A. & 2 & $\mathrm{M}$ & 1 & Classe II completa & 12,33 & 22,55 & 1,88 \\
\hline 45. T.D.S. & 2 & $\mathrm{~F}$ & 2 & Classe II completa & 13,17 & 34,88 & 2,91 \\
\hline 46. V.R.M. & 2 & $\mathrm{~F}$ & 1 & Classe II completa & 14,25 & 22,03 & 1,84 \\
\hline 47. W.A.V.B. & 2 & $\mathrm{M}$ & 1 & Classe II completa & 13,00 & 26,66 & 2,22 \\
\hline 48. W.B. & 2 & $\mathrm{M}$ & 1 & Classe II completa & 13,00 & 31,00 & 2,58 \\
\hline
\end{tabular}


TABELA A - 3

\begin{tabular}{|l|c|c|c|c|c|c|}
\hline \hline \multicolumn{1}{|c|}{ Paciente } & Grupo & IPT I & IPT F & Dif IPT & Pc IPT & IetIPT \\
\hline \hline 1. A.O. & 1 & 2,72 & 0 & 2,72 & 100,00 & 2,54 \\
\hline 2. A.L.B. & 1 & 7,32 & 0 & 7,32 & 100,00 & 1,36 \\
\hline 3. A.G. & 1 & 3,8 & 0,27 & 3,53 & 92,89 & 2,04 \\
\hline 4. B.H.B. & 1 & 7,37 & 1,5 & 5,87 & 79,65 & 1,46 \\
\hline 5. B.D.F. & 1 & 4,02 & 0,27 & 3,75 & 93,28 & 2,49 \\
\hline 6. C.T.P.D. & 1 & 6,97 & 1,5 & 5,47 & 78,48 & 3,15 \\
\hline 7. C.P.G. & 1 & 6,77 & 1,5 & 5,27 & 77,84 & 2,44 \\
\hline 8. C.R. & 1 & 5,75 & 0,27 & 5,48 & 95,30 & 2,11 \\
\hline 9. F.N.O. & 1 & 8,77 & 4,7 & 4,07 & 46,41 & 1,36 \\
\hline 10. F.P.G. & 1 & 7,17 & 0 & 7,17 & 100,00 & 1,79 \\
\hline 11. H.A.C.P. & 1 & 3,4 & 0 & 3,40 & 100,00 & 3,24 \\
\hline 12. H.M.C. & 1 & 6,05 & 0,27 & 5,78 & 95,54 & 1,82 \\
\hline 13. L.P. & 1 & 5,52 & 0,27 & 5,25 & 95,11 & 2,58 \\
\hline 14. L.Z.I. & 1 & 6,04 & 0,27 & 5,77 & 95,53 & 2,57 \\
\hline 15. M.B.V. & 1 & 6,37 & 1,5 & 4,87 & 76,45 & 1,34 \\
\hline 16. N.M.N.O. & 1 & 5,42 & 0 & 5,42 & 100,00 & 2,78 \\
\hline 17. R.C.O. & 1 & 6,07 & 0,27 & 5,80 & 95,55 & 1,68 \\
\hline 18. R.Z.I. & 1 & 4,3 & 0,27 & 4,03 & 93,72 & 2,16 \\
\hline 19. R.S.L. & 1 & 8,47 & 1,27 & 7,20 & 85,01 & 1,31 \\
\hline 20. S.B.H. & 1 & 7,27 & 1,5 & 5,77 & 79,37 & 1,42 \\
\hline 21. T.G.Q. & 1 & 5,52 & 2,6 & 2,92 & 52,90 & 1,30 \\
\hline 22. V.B. & 1 & 8,07 & 0,27 & 7,80 & 96,65 & 1,91 \\
\hline 23. A.M.G. & 2 & 5,67 & 0,27 & 5,40 & 95,24 & 6,88 \\
\hline 24. A.M. & 2 & 8,67 & 1,50 & 7,17 & 82,70 & 3,81 \\
\hline 25. A.G.B & 2 & 7,27 & 1,77 & 5,50 & 75,65 & 2,84 \\
\hline 26. E.K. & 2 & 7,37 & 0,27 & 7,10 & 96,34 & 5,17 \\
\hline 27. E.S.P. & 2 & 7,07 & 0,27 & 6,80 & 96,18 & 4,36 \\
\hline 28. E.A.M. & 2 & 8,07 & 0,27 & 7,80 & 96,65 & 3,89 \\
\hline 29. E.C.D. & 2 & 5,57 & 0,00 & 5,57 & 100,00 & 5,36 \\
\hline 30. H.A.J.S. & 2 & 7,57 & 1,50 & 6,07 & 80,18 & 3,71 \\
\hline 31. H.S.S. & 2 & 7,77 & 0,27 & 7,50 & 96,53 & 6,19 \\
\hline 32. I.A.F.M. & 2 & 8,47 & 1,50 & 6,97 & 82,29 & 7,47 \\
\hline 33. J.O. & 2 & 6,97 & 0,27 & 6,70 & 96,13 & 2,56 \\
\hline 34. L.F.D. & 2 & 7,57 & 0,00 & 7,57 & 100,00 & 4,22 \\
\hline 35. L.J.P.P. & 2 & 9,27 & 0,37 & 8,90 & 96,01 & 3,86 \\
\hline 36. L.C.M. & 2 & 8,27 & 1,50 & 6,77 & 81,86 & 3,49 \\
\hline 37. L.A.B.P. & 2 & 7,17 & 1,77 & 5,40 & 75,31 & 4,15 \\
\hline 38. L.G.C.R. & 2 & 10,77 & 0,37 & 10,40 & 96,56 & 4,48 \\
\hline 39. M.C.M.B. & 2 & 8,77 & 0,00 & 8,77 & 100,00 & 3,11 \\
\hline & & & & & & \\
\hline
\end{tabular}


TABELA A - 4

\begin{tabular}{|l|c|c|c|c|c|c|}
\hline \hline \multicolumn{1}{|c|}{ Paciente } & Grupo & IPT I & IPT F & Dif IPT & Pc IPT & letIPT \\
\hline \hline 40. M.F.Z.C. & 2 & 8,07 & 1,50 & 6,57 & 81,41 & 3,96 \\
\hline 41. P.G.O. & 2 & 8,47 & 1,77 & 6,70 & 79,10 & 4,08 \\
\hline 42. R.C.C. & 2 & 7,37 & 1,50 & 5,87 & 79,65 & 3,44 \\
\hline 43. R.F. & 2 & 7,77 & 1,50 & 6,27 & 80,69 & 3,67 \\
\hline 44. S.A. & 2 & 6,07 & 0,00 & 6,07 & 100,00 & 4,43 \\
\hline 45. T.D.S. & 2 & 8,67 & 0,57 & 8,10 & 93,43 & 2,68 \\
\hline 46. V.R.M. & 2 & 8,67 & 0,00 & 8,67 & 100,00 & 4,54 \\
\hline 47. W.A.V.B. & 2 & 7,77 & 0,27 & 7,50 & 96,53 & 3,62 \\
\hline 48. W.B. & 2 & 10,07 & 0,00 & 10,07 & 100,00 & 3,23 \\
\hline
\end{tabular}


TABELA A - 5

\begin{tabular}{|l|c|c|c|c|c|c|}
\hline \hline \multicolumn{1}{|c|}{ Paciente } & Grupo & PAR I & PAR F & Dif PAR & Pc PAR & letPAR \\
\hline \hline 1. A.O. & 1 & 6 & 0 & 6 & 100,00 & 2,54 \\
\hline 2. A.L.B. & 1 & 18 & 0 & 18 & 100,00 & 1,36 \\
\hline 3. A.G. & 1 & 10 & 2 & 8 & 80,00 & 1,76 \\
\hline 4. B.H.B. & 1 & 14 & 7 & 7 & 50,00 & 0,91 \\
\hline 5. B.D.F. & 1 & 18 & 5 & 13 & 72,22 & 1,93 \\
\hline 6. C.T.P.D. & 1 & 13 & 2 & 11 & 84,62 & 3,39 \\
\hline 7. C.P.G. & 1 & 19 & 7 & 12 & 63,16 & 1,98 \\
\hline 8. C.R. & 1 & 23 & 2 & 21 & 91,30 & 2,02 \\
\hline 9. F.N.O. & 1 & 20 & 13 & 7 & 35,00 & 1,03 \\
\hline 10. F.P.G. & 1 & 16 & 4 & 12 & 75,00 & 1,35 \\
\hline 11. H.A.C.P. & 1 & 13 & 3 & 10 & 76,92 & 2,49 \\
\hline 12. H.M.C. & 1 & 19 & 2 & 17 & 89,47 & 1,70 \\
\hline 13. L.P. & 1 & 10 & 2 & 8 & 80,00 & 2,17 \\
\hline 14. L.Z.I. & 1 & 16 & 4 & 12 & 75,00 & 2,02 \\
\hline 15. M.B.V. & 1 & 18 & 4 & 14 & 77,78 & 1,36 \\
\hline 16. N.M.N.O. & 1 & 22 & 0 & 22 & 100,00 & 2,78 \\
\hline 17. R.C.O. & 1 & 17 & 4 & 13 & 76,47 & 1,34 \\
\hline 18. R.Z.I. & 1 & 5 & 3 & 2 & 40,00 & 0,92 \\
\hline 19. R.S.L. & 1 & 26 & 6 & 20 & 76,92 & 1,19 \\
\hline 20. S.B.H. & 1 & 16 & 4 & 12 & 75,00 & 1,34 \\
\hline 21. T.G.Q. & 1 & 17 & 15 & 2 & 11,76 & 0,29 \\
\hline 22. V.B. & 1 & 14 & 4 & 10 & 71,43 & 1,41 \\
\hline 23. A.M.G. & 2 & 18 & 0 & 18 & 100,00 & 7,22 \\
\hline 24. A.M. & 2 & 26 & 12 & 14 & 53,85 & 2,48 \\
\hline 25. A.G.B & 2 & 24 & 3 & 21 & 87,50 & 3,28 \\
\hline 26. E.K. & 2 & 10 & 5 & 5 & 50,00 & 2,68 \\
\hline 27. E.S.P. & 2 & 17 & 0 & 17 & 100,00 & 4,53 \\
\hline 28. E.A.M. & 2 & 27 & 0 & 27 & 100,00 & 4,02 \\
\hline 29. E.C.D. & 2 & 12 & 0 & 12 & 100,00 & 5,36 \\
\hline 30. H.A.J.S. & 2 & 25 & 4 & 21 & 84,00 & 3,88 \\
\hline 31. H.S.S. & 2 & 22 & 2 & 20 & 90,91 & 5,83 \\
\hline 32. I.A.F.M. & 2 & 28 & 4 & 24 & 85,71 & 7,78 \\
\hline 33. J.O. & 2 & 15 & 6 & 9 & 60,00 & 1,60 \\
\hline 34. L.F.D. & 2 & 19 & 0 & 19 & 100,00 & 4,22 \\
\hline 35. L.J.P.P. & 2 & 41 & 0 & 41 & 100,00 & 4,02 \\
\hline 36. L.C.M. & 2 & 23 & 5 & 18 & 78,26 & 3,34 \\
\hline 37. L.A.B.P. & 2 & 22 & 10 & 12 & 54,55 & 3,01 \\
\hline 38. L.G.C.R. & 2 & 33 & 2 & 31 & 93,94 & 4,36 \\
\hline 39. M.C.M.B. & 2 & 28 & 0 & 28 & 100,00 & 3,11 \\
\hline
\end{tabular}


TABELA A - 6

\begin{tabular}{|l|c|c|c|c|c|c|}
\hline \hline \multicolumn{1}{|c|}{ Paciente } & Grupo & PAR I & PAR F & Dif PAR & Pc PAR & letPAR \\
\hline \hline 40. M.F.Z.C. & 2 & 31 & 4 & 27 & 87,10 & 4,24 \\
\hline 41. P.G.O. & 2 & 31 & 5 & 26 & 83,87 & 4,33 \\
\hline 42. R.C.C. & 2 & 18 & 4 & 14 & 77,78 & 3,36 \\
\hline 43. R.F. & 2 & 22 & 4 & 18 & 81,82 & 3,72 \\
\hline 44. S.A. & 2 & 20 & 0 & 20 & 100,00 & 4,43 \\
\hline 45. T.D.S. & 2 & 27 & 2 & 25 & 92,59 & 2,65 \\
\hline 46. V.R.M. & 2 & 39 & 0 & 39 & 100,00 & 4,54 \\
\hline 47. W.A.V.B. & 2 & 29 & 4 & 25 & 86,21 & 3,23 \\
\hline 48. W.B. & 2 & 33 & 0 & 33 & 100,00 & 3,23 \\
\hline
\end{tabular}


TABELA A - 7

\begin{tabular}{|c|c|c|c|c|c|c|c|c|c|}
\hline Paciente & Grupo & SNA & Co-A & A-Nperp & SNB & Co-Gn & Go-Gn & Co-Go & Pog-Nperp \\
\hline 1. A.O. & 1 & 75,8 & 84,2 & $-3,4$ & 73,9 & 107,7 & 67,5 & 48,6 & $-7,7$ \\
\hline 2. A.L.B. & 1 & 82 & 80,9 & $-3,1$ & 78,9 & 103,8 & 68,2 & 49,8 & $-9,3$ \\
\hline 3. A.G. & 1 & 84,2 & 88,3 & 3,2 & 81,2 & 111,9 & 78,8 & 52,9 & 3,5 \\
\hline 4. B.H.B. & 1 & 85,6 & 88,4 & 6,3 & 81,8 & 113 & 75 & 52,7 & 7,5 \\
\hline 5. B.D.F. & 1 & 83 & 88,1 & 1,3 & 79,7 & 107,2 & 69,8 & 52,7 & $-1,8$ \\
\hline 6. C.T.P.D. & 1 & 84 & 87,9 & 0,6 & 79,5 & 109,3 & 72,6 & 59,6 & $-4,2$ \\
\hline 7. C.P.G. & 1 & 82,1 & 89,4 & 2,3 & 76,5 & 110 & 70 & 55,5 & $-2,1$ \\
\hline 8. C.R. & 1 & 82,2 & 86,4 & $-1,5$ & 76,6 & 106,3 & 67,8 & 50,2 & $-10,7$ \\
\hline 9. F.N.O. & 1 & 85,6 & 98,2 & 1,6 & 77,6 & 119,2 & 75,6 & 55,4 & $-8,9$ \\
\hline 10. F.P.G. & 1 & 84,1 & 88,7 & $-2,4$ & 80,1 & 113,4 & 75,4 & 55,2 & $-6,6$ \\
\hline 11. H.A.C.P. & 1 & 82 & 85,2 & $-2,3$ & 77,8 & 108,9 & 69,4 & 49,6 & $-8,8$ \\
\hline 12. H.M.C. & 1 & 88,4 & 82,6 & 3,8 & 83,7 & 104,4 & 65,6 & 52,3 & 0,5 \\
\hline 13. L.P. & 1 & 75,1 & 83,3 & $-2,1$ & 72,4 & 108,8 & 70,3 & 52,9 & $-4,6$ \\
\hline 14. L.Z.I. & 1 & 85,3 & 85,6 & 6,2 & 80,2 & 105,3 & 68,2 & 52,2 & 3,3 \\
\hline 15. M.B.V. & 1 & 80,9 & 80,1 & $-1,1$ & 78,3 & 101,2 & 69,3 & 46,3 & $-4,2$ \\
\hline 16. N.M.N.O. & 1 & 81 & 78,9 & 0,6 & 74,6 & 95,7 & 64,2 & 43,7 & $-8,2$ \\
\hline 17. R.C.O. & 1 & 85,6 & 86 & 2,5 & 79,8 & 112,6 & 73,3 & 51,8 & $-6,6$ \\
\hline 18. R.Z.I. & 1 & 85,1 & 80,9 & 4 & 78,9 & 106,5 & 66,4 & 53,7 & $-2,1$ \\
\hline 19. R.S.L. & 1 & 80,5 & 76,9 & 2,8 & 75,1 & 102 & 63,8 & 50 & $-4,6$ \\
\hline 20. S.B.H. & 1 & 83,3 & 84,7 & 6,1 & 75,9 & 108,3 & 69,1 & 53,5 & 1,4 \\
\hline 21. T.G.Q. & 1 & 79,6 & 89,9 & 3,2 & 75,8 & 113,3 & 75,9 & 53,4 & $-0,5$ \\
\hline 22. V.B. & 1 & 85,1 & 97,2 & 0,3 & 79,5 & 114,8 & 76,7 & 58,7 & $-3,1$ \\
\hline 23. A.M.G. & 2 & 76,5 & 79,7 & $-11,1$ & 75,3 & 109,8 & 73,5 & 49,3 & $-21,5$ \\
\hline 24. A.M. & 2 & 82,4 & 98,2 & 2,4 & 78,9 & 123,2 & 83,3 & 59,6 & $-0,3$ \\
\hline 25. A.G.B & 2 & 86,9 & 96,3 & 4,2 & 78,3 & 108,6 & 74,5 & 51,1 & $-6,3$ \\
\hline 26. E.K. & 2 & 83,2 & 86,8 & 0,7 & 77,4 & 106,9 & 70,2 & 51,2 & $-9,9$ \\
\hline 27. E.S.P. & 2 & 80,7 & 90,4 & $-1,4$ & 78,1 & 113,9 & 75,8 & 56,1 & $-4,8$ \\
\hline 28. E.A.M. & 2 & 88 & 94,3 & 4 & 83,5 & 120,3 & 73,3 & 59,6 & 1,2 \\
\hline 29. E.C.D. & 2 & 81,9 & 82,9 & $-0,5$ & 75,5 & 111,8 & 72,1 & 49,9 & $-10,5$ \\
\hline 30. H.A.J.S. & 2 & 79,5 & 78,6 & $-0,8$ & 75,4 & 100,7 & 62,6 & 47,7 & -6 \\
\hline 31. H.S.S. & 2 & 82,4 & 86 & 4,6 & 75,1 & 106,4 & 64,9 & 52,8 & $-2,7$ \\
\hline 32. I.A.F.M. & 2 & 81,9 & 82,1 & $-3,1$ & 76 & 100,9 & 66,8 & 45,8 & $-14,3$ \\
\hline 33. J.O. & 2 & 87,8 & 97,1 & 6,7 & 78,4 & 116,1 & 72,6 & 53,9 & $-3,3$ \\
\hline 34. L.F.D. & 2 & 82,8 & 91,5 & 2,5 & 76,9 & 110,1 & 68,8 & 54,5 & $-4,7$ \\
\hline 35. L.J.P.P. & 2 & 82,5 & 89,1 & 1,9 & 80,5 & 118,4 & 73,3 & 58,9 & 1,7 \\
\hline 36. L.C.M. & 2 & 78,2 & 82,9 & $-1,4$ & 77,5 & 107,8 & 69,6 & 50,2 & $-0,3$ \\
\hline 37. L.A.B.P. & 2 & 83,7 & 85,1 & 1,3 & 79,2 & 111,8 & 76,8 & 47,8 & $-5,7$ \\
\hline 38. L.G.C.R. & 2 & 74,5 & 77,2 & $-3,7$ & 69,8 & 99,1 & 64,1 & 44,5 & $-14,1$ \\
\hline 39. М.С.М.В. & 2 & 79,1 & 87,6 & $-0,9$ & 73,8 & 105,6 & 65,7 & 52,3 & -12 \\
\hline
\end{tabular}


TABELA A - 8

\begin{tabular}{|l|c|c|c|c|c|c|c|c|c|}
\hline \hline \multicolumn{1}{|c|}{ Paciente } & Grupo & SNA & Co-A & A-Nperp & SNB & Co-Gn & Go-Gn & Co-Go & Pog-Nperp \\
\hline \hline 40. M.F.Z.C. & 2 & 79 & 81,3 & $-8,7$ & 77,3 & 100,3 & 63,8 & 48,1 & $-17,6$ \\
\hline 41. P.G.O. & 2 & 84,3 & 85,7 & $-0,6$ & 77 & 101,8 & 66,3 & 44,6 & $-11,9$ \\
\hline 42. R.C.C. & 2 & 78,5 & 84,6 & $-3,5$ & 77,9 & 113,5 & 72,5 & 55,2 & -3 \\
\hline 43. R.F. & 2 & 79,4 & 80,2 & 0,6 & 76,6 & 101,7 & 67,4 & 45,9 & 0,1 \\
\hline 44. S.A. & 2 & 83,8 & 93,8 & 0,5 & 78,4 & 111,7 & 71,3 & 50 & $-9,4$ \\
\hline 45. T.D.S. & 2 & 75,7 & 71,2 & $-1,1$ & 75,1 & 98,9 & 63,7 & 45,8 & 0,9 \\
\hline 46. V.R.M. & 2 & 84,4 & 84,7 & 0,5 & 79,8 & 105,9 & 68,5 & 52 & $-5,1$ \\
\hline 47. W.A.V.B. & 2 & 74,4 & 79,4 & $-6,5$ & 74,3 & 105,5 & 68,4 & 46,8 & $-11,2$ \\
\hline 48. W.B. & 2 & 79,1 & 87,3 & -3 & 74,5 & 107,5 & 72 & 55,7 & $-7,9$ \\
\hline
\end{tabular}


TABELA A - 9

\begin{tabular}{|c|c|c|c|c|c|c|c|c|}
\hline Paciente & Grupo & ANB & WITS & Co-A/Co-Gn & FMA & SN.GoGn & SN.PP & AFAI \\
\hline 1. A.O. & 1 & 1,8 & -1 & \begin{tabular}{|l|}
78,2 \\
\end{tabular} & 33,5 & 41,2 & 12,4 & 64,7 \\
\hline 2. A.L.B. & 1 & 3,2 & 3,1 & 78 & 27,2 & 29,8 & 2 & 59,4 \\
\hline 3. A.G. & 1 & 3 & $-0,8$ & 78,9 & 19,8 & 26,6 & 5,3 & 61,2 \\
\hline 4. B.H.B. & 1 & 3,9 & 1,2 & 78,2 & 17,9 & 28,3 & 8,4 & 60,9 \\
\hline 5. B.D.F. & 1 & 3,3 & 2,2 & 82,2 & 18,6 & 25,4 & 6,4 & 55,5 \\
\hline 6. C.T.P.D. & 1 & 4,4 & 4,5 & 80,4 & 17,1 & 21,8 & 6 & 63,8 \\
\hline 7. C.P.G. & 1 & 5,6 & 6 & 81,3 & 20,7 & 29 & 6,2 & 63,4 \\
\hline 8. C.R. & 1 & 5,6 & 3,9 & 81,3 & 28,9 & 33,2 & 8,4 & 66,3 \\
\hline 9. F.N.O. & 1 & 8 & 8,1 & 82,4 & 29,7 & 33,7 & 5,4 & 71,7 \\
\hline 10. F.P.G. & 1 & 4 & 6,9 & 78,2 & 21,9 & 24,3 & 3,8 & 67,7 \\
\hline 11. H.A.C.P. & 1 & 4,3 & 2 & 78,3 & 31,1 & 34,6 & 4,2 & 66,5 \\
\hline 12. H.M.C. & 1 & 4,8 & 3,3 & 79,2 & 22,2 & 26,7 & 1,5 & 58,8 \\
\hline 13. L.P. & 1 & 2,7 & 1,4 & 76,6 & 25,8 & 36,3 & 12,9 & 64 \\
\hline 14. L.Z.I. & 1 & 5,2 & 1,3 & 81,3 & 20,1 & 28,9 & 4,5 & 58,3 \\
\hline 15. M.B.V. & 1 & 2,6 & 4,8 & 79,1 & 23,5 & 28,9 & $-2,2$ & 63,1 \\
\hline 16. N.M.N.O. & 1 & 6,4 & 4,4 & 82,5 & 28,7 & 36,2 & 8,2 & 63 \\
\hline 17. R.C.O. & 1 & 5,8 & 3,2 & 76,3 & 32,4 & 37,1 & 3,4 & 75,7 \\
\hline 18. R.Z.I. & 1 & 6,2 & 3,4 & 76 & 29 & 35,4 & 5,1 & 66,7 \\
\hline 19. R.S.L. & 1 & 5,4 & 3,5 & 75,4 & 31,7 & 41,7 & 7,5 & 65,4 \\
\hline 20. S.B.H. & 1 & 7,4 & 5,1 & 78,2 & 25,1 & 36,2 & 8,8 & 64 \\
\hline 21. T.G.Q. & 1 & 3,8 & 1,9 & 79,4 & 23,4 & 35,1 & 13,7 & 63,6 \\
\hline 22. V.B. & 1 & 5,7 & 6,3 & 84,7 & 15,5 & 18,7 & 9,3 & 55,9 \\
\hline 23. A.M.G. & 2 & 1,2 & 1,9 & 72,6 & 36,5 & 36,9 & 3,7 & 76,8 \\
\hline 24. A.M. & 2 & 3,5 & 7,2 & 79,7 & 20,8 & 28 & 6,3 & 67,4 \\
\hline 25. A.G.B & 2 & 8,6 & 6,5 & 88,7 & 21,6 & 26,5 & 9,6 & 56,2 \\
\hline 26. E.K. & 2 & 5,8 & 1,7 & 81,2 & 28,2 & 32,8 & 7,2 & 66,7 \\
\hline 27. E.S.P. & 2 & 2,6 & 5,3 & 79,4 & 21,3 & 26,8 & 2,4 & 66,9 \\
\hline 28. E.A.M. & 2 & 4,5 & 3,2 & 78,4 & 24 & 28,3 & 1,2 & 67,6 \\
\hline 29. E.C.D. & 2 & 6,4 & 7,5 & 74,2 & 36,6 & 41,8 & 2,6 & 75,2 \\
\hline 30. H.A.J.S. & 2 & 4,2 & 4,7 & 78 & 27,8 & 35,2 & 1,7 & 61,9 \\
\hline 31. H.S.S. & 2 & 7,3 & 6,2 & 80,9 & 26,2 & 36,2 & 1,1 & 66,5 \\
\hline 32. I.A.F.M. & 2 & 6 & 4,6 & 81,4 & 31,3 & 33,2 & 5,3 & 63,7 \\
\hline 33. J.O. & 2 & 9,4 & 7,1 & 83,6 & 25 & 33,5 & 4,2 & 67 \\
\hline 34. L.F.D. & 2 & 5,9 & 5,1 & 83,1 & 23 & 31,3 & 4 & 64,4 \\
\hline 35. L.J.P.P. & 2 & 2 & 2,4 & 75,3 & 23,5 & 30,5 & 4,7 & 70,2 \\
\hline 36. L.C.M. & 2 & 0,7 & 1,6 & 76,8 & 23,3 & 31,6 & 6 & 60,3 \\
\hline 37. L.A.B.P. & 2 & 4,5 & 2,8 & 76,1 & 31,1 & 36,8 & 1,9 & 73,1 \\
\hline 38. L.G.C.R. & 2 & 4,7 & 6,7 & 77,9 & 32,5 & 42,3 & 4,8 & 65,3 \\
\hline 39. M.C.M.B. & 2 & 5,3 & 6,7 & 82,9 & 26,8 & 35,2 & 9,6 & 62,8 \\
\hline
\end{tabular}


TABELA A - 10

\begin{tabular}{|l|c|c|c|c|c|c|c|c|}
\hline \hline Paciente & Grupo & ANB & WITS & Co-A/Co-Gn & FMA & SN.GoGn & SN.PP & AFAI \\
\hline \hline 40. M.F.Z.C. & 2 & 1,6 & 3,1 & 81,1 & 28,1 & 27,5 & 8,4 & 56 \\
\hline 41. P.G.O. & 2 & 7,2 & 4,7 & 84,2 & 31,2 & 34,2 & 10 & 60,5 \\
\hline 42. R.C.C. & 2 & 0,5 & 4,5 & 74,6 & 23,7 & 29,7 & 1,3 & 66,4 \\
\hline 43. R.F. & 2 & 2,8 & 4,6 & 78,8 & 22,9 & 32,1 & 4,9 & 57,4 \\
\hline 44. S.A. & 2 & 5,5 & 4,3 & 83,9 & 29 & 33,7 & 6,9 & 67,2 \\
\hline 45. T.D.S. & 2 & 0,6 & 0,5 & 72 & 25,5 & 36,8 & 10 & 59,1 \\
\hline 46. V.R.M. & 2 & 4,7 & 7,9 & 80 & 22,9 & 27,2 & 5,4 & 59,6 \\
\hline 47. W.A.V.B. & 2 & 0 & 2,9 & 75,3 & 31 & 37,1 & 3,7 & 66,2 \\
\hline 48. W.B. & 2 & 4,6 & 8,7 & 81,2 & 16,1 & 21,8 & 1,7 & 60,3 \\
\hline
\end{tabular}


TABELA A - 11

\begin{tabular}{|c|c|c|c|c|c|c|c|c|}
\hline Paciente & Grupo & 1.PP & 1.NA & 1-NA & 1-ENAperp & 1-PP & 6-PP & 6-ENAperp \\
\hline 1. A.O. & 1 & 110,6 & 22,4 & 4,7 & $-2,2$ & 26,9 & 22,4 & $-27,4$ \\
\hline 2. A.L.B. & 1 & 109,5 & 25,5 & 5,3 & $-1,2$ & 27,7 & 20,9 & $-29,1$ \\
\hline 3. A.G. & 1 & 108,2 & 18,8 & 5 & 0,6 & 28,4 & 21 & -26 \\
\hline 4. B.H.B. & 1 & 111,5 & 17,4 & 3,3 & 0,9 & 26,8 & 22,5 & $-26,6$ \\
\hline 5. B.D.F. & 1 & 125,7 & 36,2 & 6,6 & 1,8 & 22,8 & 18,9 & $-26,7$ \\
\hline 6. C.T.P.D. & 1 & 101,7 & 11,8 & 2,6 & $-3,5$ & 29,7 & 23,8 & $-30,8$ \\
\hline 7. C.P.G. & 1 & 104,9 & 16,6 & 0,2 & $-6,9$ & 27,4 & 22,3 & $-29,7$ \\
\hline 8. C.R. & 1 & 107,6 & 17,1 & 4,4 & 0,3 & 29,4 & 23,3 & $-25,4$ \\
\hline 9. F.N.O. & 1 & 101,4 & 10,5 & 0,8 & $-7,4$ & 31,1 & 23,6 & $-32,4$ \\
\hline 10. F.P.G. & 1 & 104,8 & 17 & 1,6 & $-5,3$ & 28 & 24,6 & $-30,3$ \\
\hline 11. H.A.C.P. & 1 & 109,9 & 23,7 & 4,5 & $-4,4$ & 28,1 & 20,5 & -32 \\
\hline 12. H.M.C. & 1 & 114,1 & 24,2 & 3,8 & $-2,4$ & 25,1 & 20,7 & $-27,7$ \\
\hline 13. L.P. & 1 & 102,9 & 14,9 & 2,7 & $-4,7$ & 29,2 & 24,6 & $-28,7$ \\
\hline 14. L.Z.I. & 1 & 110,1 & 20,3 & 3 & $-2,1$ & 27,4 & 19,7 & $-28,2$ \\
\hline 15. M.B.V. & 1 & 112,1 & 33,5 & 7,8 & $-1,3$ & 28,8 & 21,4 & -31 \\
\hline 16. N.M.N.O. & 1 & 106,6 & 17,4 & 2,4 & $-3,9$ & 27,7 & 21 & $-28,1$ \\
\hline 17. R.C.O. & 1 & 104,5 & 15,6 & 5,8 & 0,9 & 34,7 & 28,4 & $-24,9$ \\
\hline 18. R.Z.I. & 1 & 112,6 & 22,4 & 3,9 & $-2,8$ & 27,9 & 22,6 & $-30,7$ \\
\hline 19. R.S.L. & 1 & 122,2 & 34,2 & 7,2 & 1,4 & 27,3 & 21 & $-27,4$ \\
\hline 20. S.B.H. & 1 & 105,6 & 13,5 & 1,3 & $-2,9$ & 27 & 21,5 & $-27,8$ \\
\hline 21. T.G.Q. & 1 & 113,1 & 19,7 & 1,1 & $-4,6$ & 27,9 & 23,7 & $-30,6$ \\
\hline 22. V.B. & 1 & 98 & 3,6 & $-2,3$ & $-4,6$ & 23,7 & 19,2 & $-29,6$ \\
\hline 23. A.M.G. & 2 & 104,5 & 24,3 & 8,5 & $-2,3$ & 36,2 & 31,5 & $-26,2$ \\
\hline 24. A.M. & 2 & 129,2 & 40,5 & 11,1 & 5,4 & 27 & 25,7 & $-28,9$ \\
\hline 25. A.G.B & 2 & 112,9 & 16,4 & 0,4 & $-2,8$ & 24,5 & 18,8 & -29 \\
\hline 26. E.K. & 2 & 104,9 & 14,4 & 1,2 & $-2,7$ & 28,9 & 23,3 & $-25,3$ \\
\hline 27. E.S.P. & 2 & 109,4 & 26,3 & 5,5 & $-2,4$ & 30,1 & 25,5 & $-27,5$ \\
\hline 28. E.A.M. & 2 & 125,2 & 36 & 10,5 & 5 & 30,2 & 24,3 & -27 \\
\hline 29. E.C.D. & 2 & 105,1 & 20,6 & 6,3 & $-1,6$ & 31,8 & 26,1 & $-27,4$ \\
\hline 30. H.A.J.S. & 2 & 110,5 & 29,3 & 5,8 & $-1,7$ & 26,8 & 20,8 & $-27,5$ \\
\hline 31. H.S.S. & 2 & 111 & 27,5 & 4,7 & 0,7 & 32,2 & 23,3 & $-25,9$ \\
\hline 32. I.A.F.M. & 2 & 96,3 & 9,1 & $-0,7$ & $-6,6$ & 29,9 & 22,4 & $-29,4$ \\
\hline 33. J.O. & 2 & 108,3 & 16,2 & 2,3 & 0,1 & 27,2 & 22,9 & $-27,1$ \\
\hline 34. L.F.D. & 2 & 112,8 & 26 & 5,9 & $-0,3$ & 29,6 & 22,7 & $-29,8$ \\
\hline 35. L.J.P.P. & 2 & 122,5 & 35,3 & 13,1 & 6,5 & 33,4 & 27,7 & $-24,1$ \\
\hline 36. L.C.M. & 2 & 120,2 & 36,1 & 9,7 & 2,9 & 27,1 & 23 & $-26,3$ \\
\hline 37. L.A.B.P. & 2 & 102,9 & 17,3 & 5,5 & $-3,2$ & 35,8 & 30,3 & $-25,7$ \\
\hline 38. L.G.C.R. & 2 & 107,5 & 28,1 & 5,9 & $-2,3$ & 25,9 & 23,4 & $-26,9$ \\
\hline 39. M.C.M.B. & 2 & 121,1 & 32,4 & 11,3 & 6,3 & 28,4 & 23,7 & $-26,7$ \\
\hline
\end{tabular}


TABELA A - 12

\begin{tabular}{|l|c|c|c|c|c|c|c|c|}
\hline \hline \multicolumn{1}{|c|}{ Paciente } & Grupo & 1.PP & 1.NA & 1-NA & 1-ENAperp & 1-PP & 6-PP & 6-ENAperp \\
\hline \hline 40. M.F.Z.C. & 2 & 124,1 & 36,7 & 9,9 & 2,8 & 24 & 21,4 & -27 \\
\hline 41. P.G.O. & 2 & 107,4 & 13,2 & 2,2 & 1,3 & 29,2 & 23,3 & $-25,7$ \\
\hline 42. R.C.C. & 2 & 116 & 36,2 & 9,8 & $-0,4$ & 29,1 & 26,5 & $-27,3$ \\
\hline 43. R.F. & 2 & 122,4 & 38,1 & 10,6 & 4,4 & 25,1 & 20,5 & $-24,9$ \\
\hline 44. S.A. & 2 & 116,7 & 26 & 6,7 & 0,5 & 29,3 & 24 & $-30,2$ \\
\hline 45. T.D.S. & 2 & 109,1 & 23,4 & 7,3 & 1,6 & 26,5 & 22,9 & $-21,4$ \\
\hline 46. V.R.M. & 2 & 124,9 & 35,1 & 7,9 & 4,3 & 25 & 24,4 & $-23,7$ \\
\hline 47. W.A.V.B. & 2 & 125,7 & 47,6 & 16,8 & 5 & 28,5 & 24,7 & $-23,5$ \\
\hline 48. W.B. & 2 & 116,1 & 35,3 & 9,5 & $-1,2$ & 29,9 & 23,1 & $-32,8$ \\
\hline
\end{tabular}


TABELA A - 13

\begin{tabular}{|c|c|c|c|c|c|c|c|c|}
\hline Paciente & Grupo & IMPA & 1.NB & 1-NB & 1-PogPerp & 1-GoMe & 6-GoMe & 6-PogPerp \\
\hline 1. A.O. & 1 & 85,9 & 24 & 5,1 & $-10,6$ & 39 & 28,4 & -30 \\
\hline 2. A.L.B. & 1 & 89,9 & 20,2 & 2,8 & $-9,1$ & 35,8 & 25,4 & -28 \\
\hline 3. A.G. & 1 & 98,6 & 28,7 & 4,7 & $-6,6$ & 38,4 & 30,8 & $-27,4$ \\
\hline 4. B.H.B. & 1 & 97,5 & 28,6 & 3,8 & $-10,2$ & 38,5 & 28,6 & $-31,4$ \\
\hline 5. B.D.F. & 1 & 103,3 & 30,1 & 5,4 & $-4,2$ & 36,6 & 28,4 & $-26,4$ \\
\hline 6. C.T.P.D. & 1 & 100,7 & 23,9 & 4,2 & $-5,2$ & 39,9 & 30,6 & $-27,9$ \\
\hline 7. C.P.G. & 1 & 94,9 & 22,4 & 1,9 & $-10,1$ & 38,9 & 30,1 & $-27,1$ \\
\hline 8. C.R. & 1 & 95,6 & 27,3 & 6,5 & $-7,9$ & 42 & 32 & $-27,3$ \\
\hline 9. F.N.O. & 1 & 88 & 21,2 & 5,7 & $-13,4$ & 44,6 & 33,1 & $-30,3$ \\
\hline 10. F.P.G. & 1 & 94,2 & 19,7 & 1,5 & $-15,2$ & 42,5 & 32 & $-33,2$ \\
\hline 11. H.A.C.P. & 1 & 89,3 & 23,8 & 4,9 & $-12,7$ & 40,1 & 29,8 & $-32,5$ \\
\hline 12. H.M.C. & 1 & 98,5 & 30,7 & 5,6 & $-6,6$ & 37,2 & 26,7 & -27 \\
\hline 13. L.P. & 1 & 92,8 & 23,8 & 3,8 & $-10,8$ & 36,9 & 27,8 & $-30,5$ \\
\hline 14. L.Z.I. & 1 & 101,3 & 32,8 & 5,2 & $-5,1$ & 34,9 & 26,5 & $-27,4$ \\
\hline 15. M.B.V. & 1 & 93,4 & 23 & 4,6 & $-8,7$ & 39,4 & 26,7 & $-30,7$ \\
\hline 16. N.M.N.O. & 1 & 97,9 & 30,8 & 6,7 & $-7,4$ & 39 & 29,2 & $-25,9$ \\
\hline 17. R.C.O. & 1 & 94 & 33,3 & 11,3 & -6 & 46,3 & 33,6 & -26 \\
\hline 18. R.Z.I. & 1 & 97,1 & 34,2 & 8,2 & $-8,4$ & 40,5 & 29,6 & $-28,6$ \\
\hline 19. R.S.L. & 1 & 90,8 & 30 & 7,4 & $-10,7$ & 40,2 & 28,3 & -30 \\
\hline 20. S.B.H. & 1 & 97,3 & 31,7 & 6,1 & $-10,6$ & 40 & 29,5 & $-29,7$ \\
\hline 21. T.G.Q. & 1 & 87,1 & 19,6 & 2,5 & $-11,4$ & 38,6 & 29,1 & $-30,7$ \\
\hline 22. V.B. & 1 & 95,7 & 15,8 & 0,6 & -11 & 39,6 & 30,9 & $-30,9$ \\
\hline 23. A.M.G. & 2 & 93,6 & 28 & 6,7 & -12 & 41,6 & 29,8 & $-34,3$ \\
\hline 24. A.M. & 2 & 97,9 & 27,6 & 4,2 & $-12,4$ & 44,8 & 29,9 & $-33,2$ \\
\hline 25. A.G.B & 2 & 106 & 33,3 & 5,6 & $-3,4$ & 36,7 & 27,5 & $-25,9$ \\
\hline 26. E.K. & 2 & 93,6 & 26,7 & 5,7 & $-8,6$ & 40,1 & 32,5 & $-28,3$ \\
\hline 27. E.S.P. & 2 & 91,8 & 19 & 2,8 & $-11,1$ & 40,8 & 30 & $-30,1$ \\
\hline 28. E.A.M. & 2 & 94,1 & 27,5 & 7,2 & $-11,7$ & 42,1 & 30,5 & $-34,1$ \\
\hline 29. E.C.D. & 2 & 93,2 & 32,9 & 9,4 & $-15,9$ & 44,1 & 30,4 & $-33,4$ \\
\hline 30. H.A.J.S. & 2 & 84,4 & 17,1 & 2,5 & $-13,2$ & 34,9 & 25,2 & $-30,4$ \\
\hline 31. H.S.S. & 2 & 95,5 & 29,3 & 7,3 & $-8,7$ & 39,3 & 28 & $-29,1$ \\
\hline 32. I.A.F.M. & 2 & 88,2 & 20,3 & 2,9 & $-12,7$ & 37,7 & 26,3 & $-32,1$ \\
\hline 33. J.O. & 2 & 96,1 & 29,3 & 6,4 & -7 & 40,2 & 31,3 & $-27,8$ \\
\hline 34. L.F.D. & 2 & 95,1 & 24,8 & 4,6 & $-10,4$ & 38,7 & 28,8 & -32 \\
\hline 35. L.J.P.P. & 2 & 88,5 & 22 & 5,3 & -10 & 43,8 & 30,6 & $-29,7$ \\
\hline 36. L.C.M. & 2 & 94 & 25,2 & 3,8 & $-12,6$ & 37 & 24,9 & $-34,2$ \\
\hline 37. L.A.B.P. & 2 & 91,9 & 29,9 & 7,1 & $-11,7$ & 40,5 & 29,2 & $-30,2$ \\
\hline 38. L.G.C.R. & 2 & 93,1 & 26,6 & 6,1 & -9 & 34,3 & 25,3 & $-30,4$ \\
\hline 39. М.С.М.В. & 2 & 101,8 & 32,3 & 7,7 & $-4,9$ & 40,8 & 27,9 & $-27,4$ \\
\hline
\end{tabular}


TABELA A - 14

\begin{tabular}{|l|c|c|c|c|c|c|c|c|}
\hline \hline \multicolumn{1}{|c|}{ Paciente } & Grupo & IMPA & 1.NB & 1-NB & 1-PogPerp & 1-GoMe & 6-GoMe & 6-PogPerp \\
\hline \hline 40. M.F.Z.C. & 2 & 88,1 & 14,3 & 0,5 & -12 & 35,4 & 25,5 & $-30,9$ \\
\hline 41. P.G.O. & 2 & 81,6 & 14,9 & 1,9 & $-13,2$ & 36,7 & 26,4 & $-30,5$ \\
\hline 42. R.C.C. & 2 & 89,9 & 19,5 & 1,5 & $-15,6$ & 36,1 & 26,4 & $-33,7$ \\
\hline 43. R.F. & 2 & 96,3 & 27 & 4,5 & $-11,1$ & 37,2 & 24,7 & $-30,8$ \\
\hline 44. S.A. & 2 & 105,2 & 39,3 & 8,4 & $-7,6$ & 42,9 & 30,2 & $-31,6$ \\
\hline 45. T.D.S. & 2 & 83,5 & 17,1 & 2,3 & $-14,6$ & 34,6 & 24,3 & $-31,9$ \\
\hline 46. V.R.M. & 2 & 97 & 25,8 & 4 & $-9,4$ & 37,9 & 26,2 & $-27,8$ \\
\hline 47. W.A.V.B. & 2 & 93,9 & 27,4 & 7,9 & $-9,2$ & 39,2 & 28,4 & -29 \\
\hline 48. W.B. & 2 & 98,9 & 17 & 1,5 & $-9,2$ & 35,5 & 26 & $-29,7$ \\
\hline
\end{tabular}


TABELA A - 15

\begin{tabular}{|l|c|c|c|c|c|c|}
\hline \hline \multicolumn{1}{|c|}{ Paciente } & Grupo & TH & THO & TV & Rel molar & Rel molar ocl \\
\hline \hline 1. A.O. & 1 & 1,8 & 2,2 & 1,8 & 0,2 & $-1,5$ \\
\hline 2. A.L.B. & 1 & 5,7 & 6,7 & 5,6 & $-0,3$ & $-1,2$ \\
\hline 3. A.G. & 1 & 4,4 & 5,4 & 5,7 & $-0,4$ & $-1,3$ \\
\hline 4. B.H.B. & 1 & 4,8 & 5,3 & 5,3 & 0,8 & 0,3 \\
\hline 5. B.D.F. & 1 & 5,1 & 5,8 & 4 & 0,9 & $-0,1$ \\
\hline 6. C.T.P.D. & 1 & 4,1 & 5,5 & 7,1 & 1,6 & 0,4 \\
\hline 7. C.P.G. & 1 & 5,4 & 6,1 & 5,9 & 1,3 & 0,7 \\
\hline 8. C.R. & 1 & 4,8 & 6,1 & 5,9 & 1,8 & 0,2 \\
\hline 9. F.N.O. & 1 & 5,9 & 7,4 & 8,4 & 1,9 & 0,8 \\
\hline 10. F.P.G. & 1 & 5 & 6,1 & 5,8 & 1,3 & 0,2 \\
\hline 11. H.A.C.P. & 1 & 4,8 & 5,6 & 4,6 & 0,2 & -1 \\
\hline 12. H.M.C. & 1 & 3,7 & 4,3 & 3,7 & 1,2 & 0,3 \\
\hline 13. L.P. & 1 & 2,3 & 3,1 & 3,8 & 0,7 & $-0,4$ \\
\hline 14. L.Z.I. & 1 & 4,6 & 5,1 & 4 & 1,6 & 0,7 \\
\hline 15. M.B.V. & 1 & 6 & 6,7 & 4,9 & 1,7 & 0,9 \\
\hline 16. N.M.N.O. & 1 & 3,5 & 4,6 & 4,9 & 1,1 & $-0,4$ \\
\hline 17. R.C.O. & 1 & 2,8 & 3,4 & 3 & 0,8 & $-0,8$ \\
\hline 18. R.Z.I. & 1 & 3,6 & 3,9 & 2,1 & $-1,1$ & -2 \\
\hline 19. R.S.L. & 1 & 6,8 & 6,9 & 2,3 & 0,8 & $-0,4$ \\
\hline 20. S.B.H. & 1 & 4,7 & 5,4 & 4,2 & 2,4 & $-0,1$ \\
\hline 21. T.G.Q. & 1 & 4,2 & 5,2 & 5,3 & 0,3 & $-0,8$ \\
\hline 22. V.B. & 1 & 4,1 & 5,7 & 9,2 & 1,7 & 0,8 \\
\hline 23. A.M.G. & 2 & 3,3 & 3,5 & 1,7 & 5,2 & 4,2 \\
\hline 24. A.M. & 2 & 11,5 & 11,9 & 5,1 & 3,8 & 3,3 \\
\hline 25. A.G.B & 2 & 5,7 & 7,3 & 7,2 & 4,8 & 2,8 \\
\hline 26. E.K. & 2 & 3,4 & 4,1 & 3,5 & 3,7 & 2,2 \\
\hline 27. E.S.P. & 2 & 5,9 & 6,1 & 5,1 & 3 & 2,7 \\
\hline 28. E.A.M. & 2 & 9,5 & 10 & 4,7 & 3,7 & 2,7 \\
\hline 29. E.C.D. & 2 & 5,6 & 5,8 & 2 & 2,8 & 2,3 \\
\hline 30. H.A.J.S. & 2 & 8,1 & 8 & 2,1 & 2,1 & 1 \\
\hline 31. H.S.S. & 2 & 6,7 & 7 & 4 & 3,2 & 2,8 \\
\hline 32. I.A.F.M. & 2 & 3,4 & 5,4 & 7,2 & 4,6 & 2,5 \\
\hline 33. J.O. & 2 & 7,7 & 7,5 & 0,9 & 3,3 & 2,5 \\
\hline 34. L.F.D. & 2 & 9 & 9,4 & 4,3 & 4,2 & 3,7 \\
\hline 35. L.J.P.P. & 2 & 10,8 & 11,8 & 7,1 & 3,4 & 2,3 \\
\hline 36. L.C.M. & 2 & 6,7 & 7,2 & 4,2 & 3,4 & 2,6 \\
\hline 37. L.A.B.P. & 2 & 4,7 & 5 & 2,5 & 4,2 & 3,5 \\
\hline 38. L.G.C.R. & 2 & 6,1 & 4,7 & $-3,8$ & 5,3 & 4,1 \\
\hline 39. M.C.M.B. & 2 & 10,3 & 11,2 & 6,2 & 4,2 & 3,3 \\
\hline
\end{tabular}


TABELA A - 16

\begin{tabular}{|l|c|c|c|c|c|c|}
\hline \hline \multicolumn{1}{|c|}{ Paciente } & Grupo & TH & THO & TV & Rel molar & Rel molar ocl \\
\hline \hline 40. M.F.Z.C. & 2 & 10,1 & 11,1 & 6,9 & 4,2 & 2,4 \\
\hline 41. P.G.O. & 2 & 9 & 10,6 & 8,7 & 4,5 & 3,4 \\
\hline 42. R.C.C. & 2 & 9 & 8,9 & 0,7 & 3,6 & 3,2 \\
\hline 43. R.F. & 2 & 9,3 & 9,9 & 5,1 & 3,7 & 2,8 \\
\hline 44. S.A. & 2 & 5,4 & 5,9 & 4,8 & 3 & 2,5 \\
\hline 45. T.D.S. & 2 & 5,6 & 6,2 & 4,2 & 3,3 & 1,9 \\
\hline 46. V.R.M. & 2 & 9,4 & 9,9 & 4,2 & 3,8 & 3,1 \\
\hline 47. W.A.V.B. & 2 & 8,9 & 8,4 & 0,9 & 4,1 & 3,1 \\
\hline 48. W.B. & 2 & 13,1 & 13,8 & 7,4 & 3,9 & 3,3 \\
\hline
\end{tabular}


TABELA A - 17

\begin{tabular}{|c|c|c|c|c|c|c|c|c|c|}
\hline Paciente & Grupo & NAPog & Conv.Teg. & $\begin{array}{l}\text { Ang. } \\
\text { Nasol. }\end{array}$ & $\mathrm{H}$-nariz & Ls-E & Li-E & Ls-APog & Li-APog \\
\hline 1. A.O. & 1 & 1,6 & 16,3 & 119,1 & 0,3 & $-0,2$ & 2,2 & 18 & 14,4 \\
\hline 2. A.L.B. & 1 & 4,1 & 13 & 113,1 & 2,5 & $-1,5$ & 0,5 & 17 & 14,8 \\
\hline 3. A.G. & 1 & 2,9 & 15,9 & 97,3 & 5 & $-3,2$ & $-1,4$ & 19,1 & 12,9 \\
\hline 4. B.H.B. & 1 & 5,9 & 7,9 & 94,8 & 7,6 & $-4,4$ & $-3,9$ & 19,1 & 16,2 \\
\hline 5. B.D.F. & 1 & 5,5 & 12,7 & 106,3 & 3 & $-1,8$ & $-0,7$ & 18,8 & 16,4 \\
\hline 6. C.T.P.D. & 1 & 6,4 & 18,2 & 94,9 & 3,6 & $-2,1$ & -1 & 19,4 & 14,2 \\
\hline 7. C.P.G. & 1 & 8 & 17,9 & 112,7 & 2,5 & $-1,4$ & $-1,3$ & 18,7 & 15 \\
\hline 8. C.R. & 1 & 8,8 & 22,5 & 93,7 & 0,9 & $-0,6$ & 2,2 & 19,8 & 15,8 \\
\hline 9. F.N.O. & 1 & 12,9 & 19,2 & 104 & 3,2 & -2 & $-3,1$ & 18,3 & 11,5 \\
\hline 10. F.P.G. & 1 & 2,1 & 15,1 & 118,2 & 6,3 & $-3,5$ & $-5,8$ & 21,1 & 13,9 \\
\hline 11. H.A.C.P. & 1 & 5 & 11,4 & 102,5 & 6,1 & $-3,6$ & $-2,2$ & 16,4 & 13,9 \\
\hline 12. H.M.C. & 1 & 8,9 & 11,3 & 85,8 & 0,2 & $-0,1$ & 0,7 & 16,5 & 13,3 \\
\hline 13. L.P. & 1 & 0,7 & 14,3 & 120,6 & 6,2 & $-3,4$ & $-1,6$ & 17,2 & 12,8 \\
\hline 14. L.Z.I. & 1 & 10,5 & 14,4 & 87 & $-0,5$ & 0,3 & 1,5 & 18,6 & 15,9 \\
\hline 15. M.B.V. & 1 & 2,3 & 9,3 & 95,1 & 2 & $-1,3$ & $-0,1$ & 16,1 & 12,4 \\
\hline 16. N.M.N.O. & 1 & 11,8 & 21,2 & 118,7 & $-0,5$ & 0,3 & 3,6 & 16,3 & 14,9 \\
\hline 17. R.C.O. & 1 & 11,2 & 10,9 & 69,6 & 0,2 & $-0,1$ & 2,7 & 22,3 & 20,8 \\
\hline 18. R.Z.I. & 1 & 11,1 & 12,2 & 92 & $-4,6$ & 2,8 & 5,3 & 18,7 & 18,2 \\
\hline 19. R.S.L. & 1 & 11 & 16,4 & 93,5 & 1,1 & $-0,7$ & 1,2 & 17,1 & 14,9 \\
\hline 20. S.B.H. & 1 & 12 & 21 & 110,6 & 0 & 0 & 0,2 & 19,2 & 14,4 \\
\hline 21. T.G.Q. & 1 & 7,2 & 18,1 & 110,7 & 6,6 & $-4,2$ & $-3,6$ & 19,9 & 15,6 \\
\hline 22. V.B. & 1 & 5,1 & 19,7 & 125,8 & 11,3 & $-5,8$ & $-5,7$ & 16,6 & 10,9 \\
\hline 23. A.M.G. & 2 & $-1,6$ & 12,2 & 127,3 & 5,3 & $-3,6$ & 0,8 & 18,1 & 16,3 \\
\hline 24. A.M. & 2 & 5,4 & 21,6 & 124,5 & $-0,9$ & 0,5 & 0,1 & 21,4 & 17,2 \\
\hline 25. A.G.B & 2 & 18,4 & 30,8 & 128,4 & 0,9 & $-0,5$ & $-0,6$ & 20,3 & 16,5 \\
\hline 26. E.K. & 2 & 12,4 & 20 & 105 & 0,3 & $-0,2$ & 1,1 & 19,5 & 17,7 \\
\hline 27. E.S.P. & 2 & 2,2 & 9,6 & 110,5 & 13,1 & $-7,8$ & $-4,3$ & 14,6 & 13,6 \\
\hline 28. E.A.M. & 2 & 7 & 19,4 & 87,9 & 1,3 & $-0,9$ & 4,3 & 22,8 & 18,5 \\
\hline 29. E.C.D. & 2 & 8,8 & 25,4 & 119,8 & 1,3 & $-0,9$ & 2,9 & 19,3 & 18 \\
\hline 30. H.A.J.S. & 2 & 4,9 & 11,1 & 110,6 & 5,6 & $-3,4$ & $-3,6$ & 14,9 & 11 \\
\hline 31. H.S.S. & 2 & 13,2 & 9 & 94,1 & 0,9 & $-0,6$ & 1,5 & 16,4 & 16 \\
\hline 32. I.A.F.M. & 2 & 9,5 & 19,7 & 122,2 & 5,3 & $-3,1$ & 0,8 & 14 & 15,2 \\
\hline 33. J.O. & 2 & 18,2 & 23,6 & 83,6 & 3,6 & $-2,7$ & $-1,4$ & 19,8 & 16,8 \\
\hline 34. L.F.D. & 2 & 10,8 & 24,2 & 128,3 & 1,9 & $-1,2$ & 2,7 & 17,1 & 16,1 \\
\hline 35. L.J.P.P. & 2 & 2,2 & 22,9 & 123,6 & 0,8 & $-0,5$ & 2,6 & 25,5 & 22,2 \\
\hline 36. L.C.M. & 2 & $-2,8$ & 9,9 & 161,4 & 3 & $-1,8$ & $-0,6$ & 17,5 & 15,1 \\
\hline 37. L.A.B.P. & 2 & 8,1 & 13,2 & 118,2 & 4,1 & $-2,5$ & 0,2 & 19,1 & 18,3 \\
\hline 38. L.G.C.R. & 2 & 6,6 & 16,1 & 118,7 & 1,7 & -1 & 0,4 & 16 & 13,9 \\
\hline 39. M.C.M.B. & 2 & 11,1 & 23,3 & 99,7 & 1,2 & $-0,8$ & $-1,2$ & 21 & 15,5 \\
\hline
\end{tabular}


TABELA A -18

\begin{tabular}{|l|c|c|c|c|c|c|c|c|c|}
\hline \hline \multicolumn{1}{r|}{ Paciente } & Grupo & NAPog & Conv.Teg. & $\begin{array}{c}\text { Ang. } \\
\text { Nasol. }\end{array}$ & H-nariz & Ls-E & Li-E & Ls-APog & Li-APog \\
\hline \hline 40. M.F.Z.C. & 2 & 0,6 & 13,3 & 92,2 & 8,8 & $-5,9$ & $-5,4$ & 17,6 & 11,8 \\
\hline 41. P.G.O. & 2 & 12,8 & 21,8 & 120 & 4,8 & $-3,1$ & 0,8 & 16,4 & 16 \\
\hline 42. R.C.C. & 2 & $-4,1$ & 7,4 & 99,8 & 9,8 & $-6,5$ & $-5,5$ & 17,7 & 12,4 \\
\hline 43. R.F. & 2 & 1,3 & 14,5 & 103,3 & $-0,7$ & 0,5 & $-1,2$ & 21,8 & 13,8 \\
\hline 44. S.A. & 2 & 11,2 & 19,4 & 91 & 2,4 & $-1,7$ & 3,1 & 20,6 & 20,2 \\
\hline 45. T.D.S. & 2 & $-3,6$ & 11,6 & 103,6 & 8,6 & $-5,8$ & $-4,1$ & 16,6 & 13,9 \\
\hline 46. V.R.M. & 2 & 7 & 19,4 & 117,2 & 2,5 & $-1,5$ & 0,4 & 18,7 & 15,9 \\
\hline 47. W.A.V.B. & 2 & $-2,7$ & 22,9 & 107,7 & $-0,6$ & 0,4 & 4,6 & 23,5 & 20 \\
\hline 48. W.B. & 2 & 2,3 & 17,3 & 100,8 & 0,9 & $-0,5$ & $-0,4$ & 20,9 & 14 \\
\hline
\end{tabular}


TABELA A -19

\section{1ํㅜraçado}

\begin{tabular}{|l|c|c|c|c|c|c|c|c|}
\hline \hline Paciente & SNA & Co-A & A-Nperp & SNB & Co-Gn & Go-Gn & Co-Go & Pog-Nperp \\
\hline \hline 1. C.R. & 82,2 & 86,4 & $-1,5$ & 76,6 & 106,3 & 67,8 & 50,2 & $-10,7$ \\
\hline 2. F.N.O. & 85,6 & 98,2 & 1,6 & 77,6 & 119,2 & 75,6 & 55,4 & $-8,9$ \\
\hline 3. F.P.G. & 84,1 & 88,7 & $-2,4$ & 80,1 & 113,4 & 75,4 & 55,2 & $-6,6$ \\
\hline 4. H.A.C.P. & 82 & 85,2 & $-2,3$ & 77,8 & 108,9 & 69,4 & 49,6 & $-8,8$ \\
\hline 5. H.M.C. & 88,4 & 82,6 & 3,8 & 83,7 & 104,4 & 65,6 & 52,3 & 0,5 \\
\hline 6. L. P. & 75,1 & 83,3 & $-2,1$ & 72,4 & 108,8 & 70,3 & 52,9 & $-4,6$ \\
\hline 7. L.Z.I. & 85,3 & 85,6 & 6,2 & 80,2 & 105,3 & 68,2 & 52,2 & 3,3 \\
\hline 8. M.B.V. & 80,9 & 80,1 & $-1,1$ & 78,3 & 101,2 & 69,3 & 46,3 & $-4,2$ \\
\hline 9. N.M.O. & 81 & 78,9 & 0,6 & 74,6 & 95,7 & 64,2 & 43,7 & $-8,2$ \\
\hline 10. R.C.O. & 85,6 & 86 & 2,5 & 79,8 & 112,6 & 73,3 & 51,8 & $-6,6$ \\
\hline 11. R.Z.I. & 85,1 & 80,9 & 4 & 78,9 & 106,5 & 66,4 & 53,7 & $-2,1$ \\
\hline 12. R.S.L. & 80,5 & 76,9 & 2,8 & 75,1 & 102 & 63,8 & 50 & $-4,6$ \\
\hline 13. S.B.H. & 83,3 & 84,7 & 6,1 & 75,9 & 108,3 & 69,1 & 53,5 & 1,4 \\
\hline 14. T.G.Q. & 79,6 & 89,9 & 3,2 & 75,8 & 113,3 & 75,9 & 53,4 & $-0,5$ \\
\hline 15. V.B. & 85,1 & 97,2 & 0,3 & 79,5 & 114,8 & 76,7 & 58,7 & $-3,1$ \\
\hline
\end{tabular}

\section{2ํㅜraçado}

\begin{tabular}{|l|c|c|c|c|c|c|c|c|}
\hline \hline Paciente & SNA & Co-A & A-Nperp & SNB & Co-Gn & Go-Gn & Co-Go & Pog-Nperp \\
\hline \hline 1. C.R. & 82,6 & 85,6 & $-2,1$ & 76,7 & 106 & 67,3 & 52,2 & $-12,2$ \\
\hline 2. F.N.O. & 85 & 98,4 & 2,6 & 77,3 & 120,2 & 78,8 & 53,2 & $-6,3$ \\
\hline 3. F.P.G. & 81,6 & 86 & $-4,3$ & 78,5 & 112,2 & 74,4 & 55,8 & $-7,2$ \\
\hline 4. H.A.C.P. & 81,8 & 85,4 & $-3,3$ & 77,8 & 109,4 & 71,7 & 47,8 & $-10,1$ \\
\hline 5. H.M.C. & 88 & 82,8 & 3,5 & 83,7 & 104,5 & 66,8 & 51,9 & 0,7 \\
\hline 6. L. P. & 76,3 & 84,3 & $-1,6$ & 73,1 & 109,7 & 72,2 & 52,8 & $-4,2$ \\
\hline 7. L.Z.I. & 87,6 & 83,8 & 5,4 & 82,1 & 102,2 & 68,7 & 48,4 & 2,1 \\
\hline 8. M.B.V. & 80,9 & 81,7 & $-1,4$ & 78,2 & 102 & 69,3 & 47,1 & $-4,7$ \\
\hline 9. N.M.O. & 80,2 & 79,4 & $-1,1$ & 73,7 & 97,4 & 63,8 & 44,8 & $-11,2$ \\
\hline 10. R.C.O. & 85,6 & 87,9 & 3,2 & 79,1 & 112,9 & 71,8 & 52,5 & $-6,7$ \\
\hline 11. R.Z.I. & 83,4 & 82,1 & 4 & 77,2 & 106,3 & 66,8 & 52,4 & $-2,2$ \\
\hline 12. R.S.L. & 81,6 & 77,2 & 2,6 & 75,8 & 101,5 & 64,6 & 48,9 & -5 \\
\hline 13. S.B.H. & 83,3 & 84,6 & 5,9 & 76,1 & 108 & 69,2 & 53,5 & 1,3 \\
\hline 14. T.G.Q. & 79,1 & 89,6 & 2,7 & 75,5 & 113,1 & 76,2 & 53,3 & $-0,7$ \\
\hline 15. V.B. & 85,4 & 97,3 & 0,5 & 79,8 & 114,8 & 76,5 & 58,8 & $-2,9$ \\
\hline
\end{tabular}


TABELA A - 20

\section{1ํㅡraçado}

\begin{tabular}{|l|c|c|c|c|c|c|c|}
\hline \hline \multicolumn{1}{|c|}{ Paciente } & ANB & WITS & Co-A/Co-Gn & FMA & SN.GoGn & SN.PP & AFAI \\
\hline \hline 1. C.R. & 5,6 & 3,9 & 81,3 & 28,9 & 33,2 & 8,4 & 66,3 \\
\hline 2. F.N.O. & 8 & 8,1 & 82,4 & 29,7 & 33,7 & 5,4 & 71,7 \\
\hline 3. F.P.G. & 4 & 6,9 & 78,2 & 21,9 & 24,3 & 3,8 & 67,7 \\
\hline 4. H.A.C.P. & 4,3 & 2 & 78,3 & 31,1 & 34,6 & 4,2 & 66,5 \\
\hline 5. H.M.C. & 4,8 & 3,3 & 79,2 & 22,2 & 26,7 & 1,5 & 58,8 \\
\hline 6. L.P. & 2,7 & 1,4 & 76,6 & 25,8 & 36,3 & 12,9 & 64 \\
\hline 7. L.Z.I. & 5,2 & 1,3 & 81,3 & 20,1 & 28,9 & 4,5 & 58,3 \\
\hline 8. M.B.V. & 2,6 & 4,8 & 79,1 & 23,5 & 28,9 & $-2,2$ & 63,1 \\
\hline 9. N.M.O. & 6,4 & 4,4 & 82,5 & 28,7 & 36,2 & 8,2 & 63 \\
\hline 10. R.C.O. & 5,8 & 3,2 & 76,3 & 32,4 & 37,1 & 3,4 & 75,7 \\
\hline 11. R.Z.I. & 6,2 & 3,4 & 76 & 29 & 35,4 & 5,1 & 66,7 \\
\hline 12. R.S.L. & 5,4 & 3,5 & 75,4 & 31,7 & 41,7 & 7,5 & 65,4 \\
\hline 13. S.B.H. & 7,4 & 5,1 & 78,2 & 25,1 & 36,2 & 8,8 & 64 \\
\hline 14. T.G.Q. & 3,8 & 1,9 & 79,4 & 23,4 & 35,1 & 13,7 & 63,6 \\
\hline 15. V.B. & 5,7 & 6,3 & 84,7 & 15,5 & 18,7 & 9,3 & 55,9 \\
\hline
\end{tabular}

\section{2ํo Traçado}

\begin{tabular}{|l|c|c|c|c|c|c|c|}
\hline \hline \multicolumn{1}{|c|}{ Paciente } & ANB & WITS & Co-A/Co-Gn & FMA & SN.GoGn & SN.PP & AFAI \\
\hline \hline 1. C.R. & 6 & 6,3 & 80,7 & 28,7 & 31,5 & 8,2 & 65,6 \\
\hline 2. F.N.O. & 7,8 & 7,2 & 81,8 & 28,3 & 34,2 & 5,2 & 70 \\
\hline 3. F.P.G. & 3 & 5,6 & 76,7 & 21,8 & 24,4 & 3,8 & 67,6 \\
\hline 4. H.A.C.P. & 4 & 0,6 & 78,1 & 33,4 & 35,5 & 4,1 & 67,4 \\
\hline 5. H.M.C. & 4,3 & 2,1 & 79,2 & 21,6 & 25,8 & 1,7 & 58,7 \\
\hline 6. L.P. & 3,1 & 1,7 & 76,9 & 25 & 35 & 11,9 & 64,5 \\
\hline 7. L.Z.I. & 5,5 & 2,5 & 82,1 & 20,2 & 26,5 & 3,4 & 57,4 \\
\hline 8. M.B.V. & 2,7 & 4,5 & 80,1 & 24,5 & 29,3 & -2 & 63,8 \\
\hline 9. N.M.O. & 6,5 & 3,6 & 81,5 & 31,8 & 37,2 & 9 & 63,4 \\
\hline 10. R.C.O. & 6,5 & 3,9 & 77,9 & 33,3 & 38,4 & 4,1 & 76,4 \\
\hline 11. R.Z.I. & 6,2 & 3,6 & 77,3 & 28,6 & 36,7 & 6,9 & 64,2 \\
\hline 12. R.S.L. & 5,8 & 3,2 & 76,1 & 31 & 39,9 & 6,3 & 64,9 \\
\hline 13. S.B.H. & 7,1 & 4,7 & 78,3 & 24,6 & 35,5 & 8,7 & 63,7 \\
\hline 14. T.G.Q. & 3,5 & 1,7 & 79,2 & 23,3 & 35,1 & 13,7 & 63,6 \\
\hline 15. V.B. & 5,6 & 6,3 & 84,8 & 15,2 & 18,2 & 8,9 & 55,7 \\
\hline
\end{tabular}


TABELA A - 21

\section{1ํㅡraçado}

\begin{tabular}{|l|c|c|c|c|c|c|c|}
\hline \hline \multicolumn{1}{|c|}{ Paciente } & 1.PP & 1.NA & 1-NA & 1-ENAperp & 1-PP & 6-PP & 6-ENAperp \\
\hline \hline 1. C.R. & 107,6 & 17,1 & 4,4 & 0,3 & 29,4 & 23,3 & $-25,4$ \\
\hline 2. F.N.O. & 101,4 & 10,5 & 0,8 & $-7,4$ & 31,1 & 23,6 & $-32,4$ \\
\hline 3. F.P.G. & 104,8 & 17 & 1,6 & $-5,3$ & 28 & 24,6 & $-30,3$ \\
\hline 4. H.A.C.P. & 109,9 & 23,7 & 4,5 & $-4,4$ & 28,1 & 20,5 & -32 \\
\hline 5. H.M.C. & 114,1 & 24,2 & 3,8 & $-2,4$ & 25,1 & 20,7 & $-27,7$ \\
\hline 6. L. P. & 102,9 & 14,9 & 2,7 & $-4,7$ & 29,2 & 24,6 & $-28,7$ \\
\hline 7. L.Z.I. & 110,1 & 20,3 & 3 & $-2,1$ & 27,4 & 19,7 & $-28,2$ \\
\hline 8. M.B.V. & 112,1 & 33,5 & 7,8 & $-1,3$ & 28,8 & 21,4 & -31 \\
\hline 9. N.M.O. & 106,6 & 17,4 & 2,4 & $-3,9$ & 27,7 & 21 & $-28,1$ \\
\hline 10. R.C.O. & 104,5 & 15,6 & 5,8 & 0,9 & 34,7 & 28,4 & $-24,9$ \\
\hline 11. R.Z.I. & 112,6 & 22,4 & 3,9 & $-2,8$ & 27,9 & 22,6 & $-30,7$ \\
\hline 12. R.S.L. & 122,2 & 34,2 & 7,2 & 1,4 & 27,3 & 21 & $-27,4$ \\
\hline 13. S.B.H. & 105,6 & 13,5 & 1,3 & $-2,9$ & 27 & 21,5 & $-27,8$ \\
\hline 14. T.G.Q. & 113,1 & 19,7 & 1,1 & $-4,6$ & 27,9 & 23,7 & $-30,6$ \\
\hline 15. V.B. & 98 & 3,6 & $-2,3$ & $-4,6$ & 23,7 & 19,2 & $-29,6$ \\
\hline
\end{tabular}

2o Traçado

\begin{tabular}{|l|c|c|c|c|c|c|c|}
\hline \hline \multicolumn{1}{|c|}{ Paciente } & 1.PP & 1.NA & 1-NA & 1-ENAperp & 1-PP & 6-PP & 6-ENAperp \\
\hline \hline 1. C.R. & 105,1 & 14,3 & 3,7 & $-0,5$ & 28,8 & 24,1 & $-26,6$ \\
\hline 2. F.N.O. & 97,8 & 7,6 & 0,6 & $-7,3$ & 31,8 & 23,4 & $-32,6$ \\
\hline 3. F.P.G. & 101,4 & 16 & 2,9 & $-6,3$ & 27,9 & 24,3 & $-31,4$ \\
\hline 4. H.A.C.P. & 111,3 & 25,4 & 5 & $-3,5$ & 27,8 & 19,6 & $-30,7$ \\
\hline 5. H.M.C. & 116 & 26,3 & 4,7 & $-2,4$ & 24,3 & 19,8 & $-28,4$ \\
\hline 6. L. P. & 108 & 19,8 & 2,3 & $-6,8$ & 29,3 & 24,7 & -31 \\
\hline 7. L.Z.I. & 112,4 & 21,4 & 2,9 & 0,2 & 26,5 & 20,6 & $-26,6$ \\
\hline 8. M.B.V. & 110,1 & 31,2 & 7 & $-2,2$ & 29 & 21,5 & $-30,8$ \\
\hline 9. N.M.O. & 105,4 & 16,3 & 1,9 & $-3,7$ & 27,8 & 20,6 & $-26,7$ \\
\hline 10. R.C.O. & 108,3 & 18,6 & 5 & 0 & 34,5 & 28,1 & $-26,8$ \\
\hline 11. R.Z.I. & 115 & 24,6 & 3,7 & 0,2 & 27 & 21,6 & $-26,6$ \\
\hline 12. R.S.L. & 122,3 & 34,3 & 6,9 & 1,3 & 28 & 21 & $-27,8$ \\
\hline 13. S.B.H. & 105 & 13 & 1,2 & -3 & 27,3 & 21,8 & $-27,7$ \\
\hline 14. T.G.Q. & 112,6 & 19,8 & 1,7 & $-4,3$ & 28,2 & 24 & $-30,3$ \\
\hline 15. V.B. & 98,3 & 3,9 & $-2,3$ & $-4,5$ & 23,8 & 19,4 & $-29,5$ \\
\hline
\end{tabular}


TABELA A - 22

\section{1o Traçado}

\begin{tabular}{|l|c|c|c|c|c|c|c|}
\hline \hline \multicolumn{1}{|c|}{ Paciente } & IMPA & 1.NB & 1-NB & 1-PogPerp & 1-GoMe & 6-GoMe & 6-PogPerp \\
\hline \hline 1. C.R. & 95,6 & 27,3 & 6,5 & $-7,9$ & 42 & 32 & $-27,3$ \\
\hline 2. F.N.O. & 88 & 21,2 & 5,7 & $-13,4$ & 44,6 & 33,1 & $-30,3$ \\
\hline 3. F.P.G. & 94,2 & 19,7 & 1,5 & $-15,2$ & 42,5 & 32 & $-33,2$ \\
\hline 4. H.A.C.P. & 89,3 & 23,8 & 4,9 & $-12,7$ & 40,1 & 29,8 & $-32,5$ \\
\hline 5. H.M.C. & 98,5 & 30,7 & 5,6 & $-6,6$ & 37,2 & 26,7 & -27 \\
\hline 6. L.P. & 92,8 & 23,8 & 3,8 & $-10,8$ & 36,9 & 27,8 & $-30,5$ \\
\hline 7. L.Z.I. & 101,3 & 32,8 & 5,2 & $-5,1$ & 34,9 & 26,5 & $-27,4$ \\
\hline 8. M.B.V. & 93,4 & 23 & 4,6 & $-8,7$ & 39,4 & 26,7 & $-30,7$ \\
\hline 9. N.M.O. & 97,9 & 30,8 & 6,7 & $-7,4$ & 39 & 29,2 & $-25,9$ \\
\hline 10. R.C.O. & 94 & 33,3 & 11,3 & -6 & 46,3 & 33,6 & -26 \\
\hline 11. R.Z.I. & 97,1 & 34,2 & 8,2 & $-8,4$ & 40,5 & 29,6 & $-28,6$ \\
\hline 12. R.S.L. & 90,8 & 30 & 7,4 & $-10,7$ & 40,2 & 28,3 & -30 \\
\hline 13. S.B.H. & 97,3 & 31,7 & 6,1 & $-10,6$ & 40 & 29,5 & $-29,7$ \\
\hline 14. T.G.Q. & 87,1 & 19,6 & 2,5 & $-11,4$ & 38,6 & 29,1 & $-30,7$ \\
\hline 15. V.B. & 95,7 & 15,8 & 0,6 & -11 & 39,6 & 30,9 & $-30,9$ \\
\hline
\end{tabular}

\section{2으 Traçado}

\begin{tabular}{|l|c|c|c|c|c|c|c|}
\hline \hline \multicolumn{1}{|c|}{ Paciente } & IMPA & 1.NB & 1-NB & 1-PogPerp & 1-GoMe & 6-GoMe & 6-PogPerp \\
\hline \hline 1. C.R. & 95,4 & 25,9 & 6,7 & $-6,4$ & 41,7 & 30,7 & -25 \\
\hline 2. F.N.O. & 86,1 & 19,1 & 5,1 & $-14,5$ & 42,3 & 30,3 & $-31,9$ \\
\hline 3. F.P.G. & 93,8 & 18,2 & 1,9 & $-13,7$ & 42 & 32,9 & $-31,8$ \\
\hline 4. H.A.C.P. & 92,2 & 28,2 & 4,5 & $-13,3$ & 40,5 & 30,9 & $-33,2$ \\
\hline 5. H.M.C. & 100,3 & 31,9 & 4,9 & $-5,5$ & 36,4 & 27,2 & $-26,6$ \\
\hline 6. L.P. & 92,8 & 23,1 & 3,4 & $-10,9$ & 36,2 & 27,6 & $-30,9$ \\
\hline 7. L.Z.I. & 102,9 & 33,6 & 4,6 & $-6,3$ & 34,1 & 25,6 & -28 \\
\hline 8. M.B.V. & 94,4 & 24,5 & 3,7 & $-8,9$ & 39 & 26,6 & $-30,4$ \\
\hline 9. N.M.O. & 97,2 & 31,4 & 6,1 & $-7,6$ & 38,7 & 29,1 & $-25,7$ \\
\hline 10. R.C.O. & 91 & 31 & 10,4 & $-7,2$ & 46,4 & 34,2 & $-25,9$ \\
\hline 11. R.Z.I. & 96,5 & 33 & 8,6 & $-7,3$ & 40 & 29,5 & $-27,5$ \\
\hline 12. R.S.L. & 94,5 & 32,4 & 7,3 & $-9,3$ & 39,1 & 28,5 & $-28,8$ \\
\hline 13. S.B.H. & 97,6 & 31,6 & 5,9 & $-10,4$ & 39,5 & 29 & $-29,8$ \\
\hline 14. T.G.Q. & 87,2 & 19,4 & 2,3 & $-11,6$ & 38,4 & 28,9 & $-30,6$ \\
\hline 15. V.B. & 96 & 16 & 0,3 & $-11,3$ & 39,1 & 30,7 & $-30,7$ \\
\hline
\end{tabular}


TABELA A - 23

\section{1ํ Traçado}

\begin{tabular}{|l|c|c|c|c|c|}
\hline \hline \multicolumn{1}{|c|}{ Paciente } & TH & THO & TV & Rel molar & Rel molar ocl \\
\hline \hline 1. C.R. & 4,8 & 6,1 & 5,9 & 1,8 & 0,2 \\
\hline 2. F.N.O. & 5,9 & 7,4 & 8,4 & 1,9 & 0,8 \\
\hline 3. F.P.G. & 5 & 6,1 & 5,8 & 1,3 & 0,2 \\
\hline 4. H.A.C.P. & 4,8 & 5,6 & 4,6 & 0,2 & -1 \\
\hline 5. H.M.C. & 3,7 & 4,3 & 3,7 & 1,2 & 0,3 \\
\hline 6. L.P. & 2,3 & 3,1 & 3,8 & 0,7 & $-0,4$ \\
\hline 7. L.Z.I. & 4,6 & 5,1 & 4 & 1,6 & 0,7 \\
\hline 8. M.B.V. & 6 & 6,7 & 4,9 & 1,7 & 0,9 \\
\hline 9. N.M.O. & 3,5 & 4,6 & 4,9 & 1,1 & $-0,4$ \\
\hline 10. R.C.O. & 2,8 & 3,4 & 3 & 0,8 & $-0,8$ \\
\hline 11. R.Z.I. & 3,6 & 3,9 & 2,1 & $-1,1$ & -2 \\
\hline 12. R.S.L. & 6,8 & 6,9 & 2,3 & 0,8 & $-0,4$ \\
\hline 13. S.B.H. & 4,7 & 5,4 & 4,2 & 2,4 & $-0,1$ \\
\hline 14. T.G.Q. & 4,2 & 5,2 & 5,3 & 0,3 & $-0,8$ \\
\hline 15. V.B. & 4,1 & 5,7 & 9,2 & 1,7 & 0,8 \\
\hline
\end{tabular}

\section{2o Traçado}

\begin{tabular}{|l|c|c|c|c|c|}
\hline \hline \multicolumn{1}{|c|}{ Paciente } & TH & THO & TV & Rel molar & Rel molar ocl \\
\hline \hline 1. C.R. & 4,3 & 5,6 & 5,7 & 1,1 & $-0,6$ \\
\hline 2. F.N.O. & 6,1 & 7,8 & 8,6 & 2,4 & 1 \\
\hline 3. F.P.G. & 4,5 & 5,4 & 5,5 & 0,2 & $-0,5$ \\
\hline 4. H.A.C.P. & 5,4 & 6 & 3,9 & 0,7 & $-0,9$ \\
\hline 5. H.M.C. & 4,7 & 5 & 2,8 & 1,6 & 0,5 \\
\hline 6. L.P. & 3 & 3,7 & 3,5 & 1,4 & 0 \\
\hline 7. L.Z.I. & 5,1 & 5,5 & 3,3 & 1,8 & 0,9 \\
\hline 8. M.B.V. & 6,2 & 6,9 & 4,5 & 2,1 & 0,6 \\
\hline 9. N.M.O. & 3,6 & 4,7 & 4,7 & 2,1 & 0 \\
\hline 10. R.C.O. & 3,9 & 4,4 & 2,9 & $-0,1$ & $-1,3$ \\
\hline 11. R.Z.I. & 3,2 & 3,6 & 2,3 & $-0,5$ & $-1,9$ \\
\hline 12. R.S.L. & 7,1 & 7,2 & 2,5 & 0,8 & $-0,5$ \\
\hline 13. S.B.H. & 4,5 & 5,3 & 4,2 & 2,3 & $-0,1$ \\
\hline 14. T.G.Q. & 4,5 & 5,5 & 5,3 & 0,3 & $-0,7$ \\
\hline 15. V.B. & 4,4 & 5,8 & 9,1 & 1,5 & 0,7 \\
\hline
\end{tabular}


TABELA A - 24

\section{1o Traçado}

\begin{tabular}{|l|c|c|c|c|c|c|c|c|}
\hline \hline Paciente & NAPog & Conv.Teg. & Ang. Nasol. & H-nariz & Ls-E & Li-E & Ls-APog & Li-APog \\
\hline \hline 1. C.R. & 8,8 & 22,5 & 93,7 & 0,9 & $-0,6$ & 2,2 & 19,8 & 15,8 \\
\hline 2. F.N.O. & 12,9 & 19,2 & 104 & 3,2 & -2 & $-3,1$ & 18,3 & 11,5 \\
\hline 3. F.P.G. & 2,1 & 15,1 & 118,2 & 6,3 & $-3,5$ & $-5,8$ & 21,1 & 13,9 \\
\hline 4. H.A.C.P. & 5 & 11,4 & 102,5 & 6,1 & $-3,6$ & $-2,2$ & 16,4 & 13,9 \\
\hline 5. H.M.C. & 8,9 & 11,3 & 85,8 & 0,2 & $-0,1$ & 0,7 & 16,5 & 13,3 \\
\hline 6. L. P. & 0,7 & 14,3 & 120,6 & 6,2 & $-3,4$ & $-1,6$ & 17,2 & 12,8 \\
\hline 7. L.Z.I. & 10,5 & 14,4 & 87 & $-0,5$ & 0,3 & 1,5 & 18,6 & 15,9 \\
\hline 8. M.B.V. & 2,3 & 9,3 & 95,1 & 2 & $-1,3$ & $-0,1$ & 16,1 & 12,4 \\
\hline 9. N.M.O. & 11,8 & 21,2 & 118,7 & $-0,5$ & 0,3 & 3,6 & 16,3 & 14,9 \\
\hline 10. R.C.O. & 11,2 & 10,9 & 69,6 & 0,2 & $-0,1$ & 2,7 & 22,3 & 20,8 \\
\hline 11. R.Z.I. & 11,1 & 12,2 & 92 & $-4,6$ & 2,8 & 5,3 & 18,7 & 18,2 \\
\hline 12. R.S.L. & 11 & 16,4 & 93,5 & 1,1 & $-0,7$ & 1,2 & 17,1 & 14,9 \\
\hline 13. S.B.H. & 12 & 21 & 110,6 & 0 & 0 & 0,2 & 19,2 & 14,4 \\
\hline 14. T.G.Q. & 7,2 & 18,1 & 110,7 & 6,6 & $-4,2$ & $-3,6$ & 19,9 & 15,6 \\
\hline 15. V.B. & 5,1 & 19,7 & 125,8 & 11,3 & $-5,8$ & $-5,7$ & 16,6 & 10,9 \\
\hline
\end{tabular}

2o Traçado

\begin{tabular}{|l|c|c|c|c|c|c|c|c|}
\hline \hline Paciente & NAPog & Conv.Teg. & Ang. Nasol. & H-nariz & Ls-E & Li-E & Ls-APog & Li-APog \\
\hline \hline 1. C.R. & 9,8 & 23,4 & 90,3 & 1,9 & $-1,3$ & 1,1 & 19 & 14,2 \\
\hline 2. F.N.O. & 12 & 20 & 104,8 & 3,7 & $-2,4$ & $-2,6$ & 19 & 12,5 \\
\hline 3. F.P.G. & $-1,1$ & 13,6 & 116,6 & 4,2 & $-2,2$ & $-4,9$ & 23 & 15,4 \\
\hline 4. H.A.C.P. & 4,5 & 12,4 & 106,2 & 6,6 & $-3,9$ & $-2,6$ & 16,3 & 13,4 \\
\hline 5. H.M.C. & 7,9 & 13 & 99,6 & 0,8 & $-0,5$ & $-0,4$ & 16,2 & 11,8 \\
\hline 6. L.P. & 1,5 & 16,3 & 115,9 & 6,2 & $-3,5$ & $-1,5$ & 17,2 & 12,4 \\
\hline 7. L.Z.I. & 10,4 & 15,4 & 93,8 & 0,2 & $-0,1$ & 0,8 & 17,8 & 14,7 \\
\hline 8. M.B.V. & 2,5 & 8,5 & 96,1 & 3,7 & $-2,4$ & $-1,1$ & 15,2 & 11,8 \\
\hline 9. N.M.O. & 11,9 & 21,6 & 114,9 & 0,3 & $-0,2$ & 3,9 & 15,5 & 15 \\
\hline 10. R.C.O. & 13,5 & 11,7 & 73 & 1,4 & $-0,9$ & 2,5 & 20,3 & 20,2 \\
\hline 11. R.Z.I. & 11,5 & 13,7 & 103,8 & $-2,8$ & 1,7 & 6,2 & 17,5 & 19,1 \\
\hline 12. R.S.L. & 11,5 & 14,7 & 97 & 2,3 & $-1,5$ & 2,2 & 15,8 & 14,8 \\
\hline 13. S.B.H. & 11,8 & 20,8 & 110,2 & $-0,2$ & 0,1 & 0,3 & 19,2 & 14,5 \\
\hline 14. T.G.Q. & 6,4 & 18 & 110,7 & 6,4 & -4 & $-3,6$ & 20,1 & 15,5 \\
\hline 15. V.B. & 5,3 & 19,5 & 126,8 & 11,5 & $-5,9$ & $-5,7$ & 16,6 & 11,1 \\
\hline
\end{tabular}


TABELA A - 25

\begin{tabular}{|l|c|c|c|}
\hline \hline \multicolumn{1}{|c|}{ Paciente } & modelo & PAR 1 medição & PAR 2 medição \\
\hline \hline 1. A.G. & inicial & 10 & 12 \\
\hline 2. B.H.B. & inicial & 14 & 14 \\
\hline 3. C.P.G. & inicial & 19 & 19 \\
\hline 4. C.P.R. & inicial & 23 & 23 \\
\hline 5. F.N.O. & inicial & 20 & 20 \\
\hline 6. F.P.G. & inicial & 13 & 13 \\
\hline 7. H.A.C.P. & inicial & 16 & 17 \\
\hline 8. R.C.O. & inicial & 4 & 4 \\
\hline 9. S.B.H. & inicial & 13 & 15 \\
\hline 10. T.G.Q. & inicial & 2 & 2 \\
\hline 11. F.O. & final & 0 & 0 \\
\hline 12. F.P.G. & final & 17 & 17 \\
\hline 13. H.M.C. & final & 4 & 4 \\
\hline 14. N.M.N.O. & final & 3 & 3 \\
\hline 15. R.C.O. & final & 6 & 6 \\
\hline 16. R.Z.I. & final & 16 & 17 \\
\hline 17. R.S.L. & final & 4 & 4 \\
\hline 18. S.B.H. & final & 17 & 17 \\
\hline 19. T.G.Q. & final & 15 & 14 \\
\hline 20. V.B. & final & 4 & 4 \\
\hline
\end{tabular}


TABELA A -26

\begin{tabular}{|l|c|c|c|}
\hline \hline \multicolumn{1}{|c|}{ Paciente } & modelo & IPT 1 1 $^{\mathbf{a}}$ medição & IPT 2 2 $^{\mathbf{a}}$ edição \\
\hline \hline 1. A.G. & inicial & 3,8 & 3,82 \\
\hline 2. B.H.B. & inicial & 7,37 & 7,07 \\
\hline 3. B.D.F. & inicial & 4,02 & 3,82 \\
\hline 4. C.P.R. & inicial & 5,75 & 7,32 \\
\hline 5. F.N.O. & inicial & 8,77 & 8,87 \\
\hline 6. F.P.G. & inicial & 7,17 & 6,17 \\
\hline 7. H.A.C.P. & inicial & 3,4 & 3,4 \\
\hline 8. L.P. & inicial & 5,52 & 5,32 \\
\hline 9. R.C.O. & inicial & 6,07 & 6,07 \\
\hline 10. S.B.H. & inicial & 7,27 & 6,67 \\
\hline 11. A.G. & final & 0,27 & 0,27 \\
\hline 12. C.P.G. & final & 1,5 & 1,27 \\
\hline 13. F.N.O. & final & 4,7 & 4,7 \\
\hline N.M.N.O. & final & 0 & 0 \\
\hline 15. M.B.V & final & 1,5 & 1,5 \\
\hline 16. R.Z.I. & final & 0,27 & 0,27 \\
\hline 17. R.S.L. & final & 1,27 & 1,27 \\
\hline 18. S.B.H. & final & 1,5 & 1,27 \\
\hline 19. T.G.Q. & final & 2,6 & 2,6 \\
\hline 20.V.B. & final & 0,27 & 0 \\
\hline
\end{tabular}

